\title{
Confirming Tradition: Confirming Change - A Social History of the Cricket Tours to New Zealand in the $1930 \mathrm{~s}$
}

\author{
Owen Mann
}
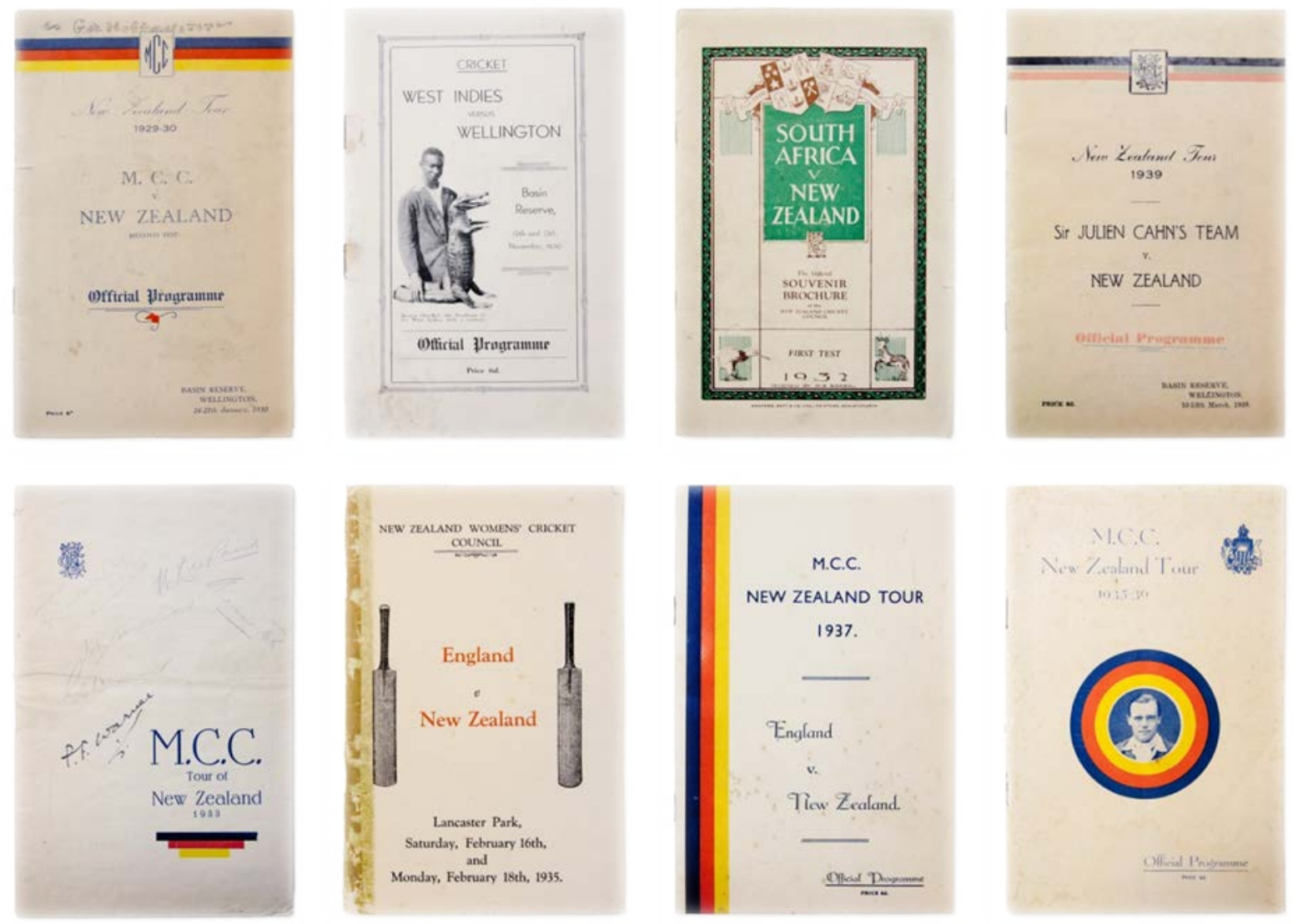

Programmes of the cricket tours to New Zealand in the 1930, courtesy of the New Zealand Cricket Museum.

A thesis submitted to the Victoria University of Wellington in fulfillment of the requirements for the degree of Master in Arts in History 


\section{Abstract}

This study examines the eight tours to New Zealand by visiting cricketing teams between 1930 and 1939. There were four tours made by the Marylebone Cricket Club along with inaugural visits by the West Indies, South Africa, an England Women's XI, and lastly the Julien Cahn XI. These tours were major events for contemporaries, attracting large crowds and much attention in the press. They are a focus for an examination of New Zealand's relations with other parts of the world, specifically other parts of the Empire. The tours were major sporting events, but also prompted wider popular and public discussion of nationhood, race, gender and the role of sport in society and the Empire.

For the New Zealand public in the 1930s, cricket was a game that connected them with their British and imperial heritage during a period of uncertainty. For the cricket community of New Zealand the tours were massive undertakings due to the substantial financial commitment required and poor results, but the tours continued because of the strong associations and core beliefs that cricket nurtured and because of a love of the game. Though these tours contained few moments of on-field achievement for the hosts they say much about how New Zealanders of that decade viewed themselves and others.

Drawing primarily on the dense contemporary press coverage 'Confirming Tradition, Confirming Change' examines cricket's capacity to operate as more than a game - it acts as a conduit for understanding the broader social attitudes and beliefs of the time. Each of the tours contains an internal narrative concerning entrenched traditions and bonds and their interplay with newer realities and considerations. Cricket was largely administered by bodies that emphasised the traditions and conservative structures of the game, but the teams themselves represented and engaged with the changing expectations and realities of sport in this decade. Cricket was changing from within, exemplified by the expansion of test cricket but also influenced by external elements such as the growth of radio commentary and cinema. This study examines the eight tours in three chronologically bracketed chapters focusing on issues of race in the tours by the MCC of 1929-30, the West Indies in 1930-31 and South Africa in 1931-32; the issue of gender and identity in the tours by the MCC of 1932-33 and the England Women of 1934-35; and issues of professionalism/commercialism and differences in player and public expectations in the tours by the MCC in 1935-36, 1936-37 and the Julien Cahn XI in 1938-39. Throughout the eight tours there were tensions between tradition and change, sometimes exhibited between New Zealand crowds and visiting teams, sometimes between administrators and players. The tours may have reflected the weakness of New Zealand cricket, but the local players' and spectators' commitment to Empire is apparent through the continued perseverance at a sport that at the time represented imperial loyalty and global British communality. 


\section{Table of Contents}

$\begin{array}{lc}\text { Abstract } & \text { i } \\ \text { Table of Contents } & \text { ii } \\ \text { Acknowledgements } & \text { iii } \\ \text { List of Abbreviations } & \text { iv } \\ \text { List of images } & \text { v }\end{array}$

$\begin{array}{ll}\text { Introduction } & 1\end{array}$

Chapter One: New Visitors - Race and the Wider Imperial World -

Duleepsinhji, the West Indies and South Africa visit, 1929-1932.

Chapter Two: Following Tradition, Confirming Change -

Jardine and Archdale and their teams in New Zealand, 1932-1935.

Chapter Three: What do people actually want from a Cricket Tour?

The MCC and Julien Cahn visit New Zealand. 1935-1939

Conclusion

126

Bibliography 


\section{Acknowledgements}

Along the journey of this thesis I have had the incredible support of Charlotte Macdonald. Her feedback, enthusiasm and guidance has been brilliant in what has at times been a difficult and frustrating journey. I will forever be grateful for her supervision over both this thesis and my earlier research essay on Edwardian cricket tours to New Zealand.

There are several people who now probably know far more about cricket in New Zealand in the 1930s than they ever needed or wanted to. I have been so fortunate to have had a band of readers who have been willing to wade into my writing. To my parents Phillip Mann and Nonnita Rees, thank you so much for the proofing but also your loving support; to Hamish; David and Kirsty who have dipped in, thank you too. Most of all, thanks to Angela Blake, who has not only had to proof my drafts, but sacrifice much of her time, energy and patience to make it possible for me to complete this project. I am forever grateful.

Thank you to the staff of the National Library, Archives New Zealand and New Zealand Cricket for your support. To David Mealing of the New Zealand Cricket Museum, thank you for your time, suggestions and the access you granted me to the Museum's collection. To the History Department, thank you for the awarding me the F. P Wilson Scholarship, which was a great and unexpected honour. Also thank you to the fellow MA and $\mathrm{PhD}$ students who I shared the department with and whose good humour and solidarity was much appreciated - good luck with your future endeavours Elizabeth, Adam, Coralie, Catherine, Jess, Carl, Grace, Rachel and Susann. 


\section{Abbreviations}

$\mathrm{ABC}$

BBC

ICC

MCC

NZCC

NZWCC

NZRFU

SARFU

WCA

WCA
Australian Board of Control

British Broadcasting Corporation

International Cricket Council

Marylebone Cricket Club

New Zealand Cricket Council

New Zealand Women's Cricket Council

New Zealand Rugby Football Union

South African Rugby Football Union

Wellington Cricket Association

England Women's Cricket Association 


\section{List of Illustrations}

1. 'MCC vs New Zealand 1929-30', Printed Ephemera Collection, p. 25 Courtesy of New Zealand Cricket Museum, Wellington.

2. 'MCC versus Auckland', New Zealand Herald, 11 February 1930, p 8.' Image reproduced courtesy of the Alexander Turnbull Library.

3. West Indies v Wellington, 1930, Official Programme, Printed Ephemera Collection, Courtesy of New Zealand Cricket Museum.

4. 'South Africa v New Zealand 1932', Souvenir Brochure, Printed Ephemera Collection, Courtesy of New Zealand Cricket Museum.

5. ' 'MCC Tour of New Zealand 1933',

Printed Ephemera Collection, Courtesy of New Zealand Cricket Museum.

6. 'England v New Zealand 1935',

Printed Ephemera Collection, Courtesy of New Zealand Cricket Museum.

7. 'Touring Women Cricketers', The Weekly News, 6 February 1935, p. 40

p. 85 reproduced courtesy of the Alexander Turnbull Library.

8. 'MCC New Zealand Tour 1935-36',

Printed Ephemera Collection, Courtesy of New Zealand Cricket Museum

p.88

p. 94 present during their visit to New Zealand. Image reproduced courtesy of Printed Ephemera Collection, New Zealand Cricket Museum.

10. 'MCC New Zealand Tour 1937',

Printed Ephemera Collection, Courtesy of New Zealand Cricket Museum.

11. 'English Cricketers Visit the Mount Cook Region' The Weekly News, 31 Mar 1937, p 57 reproduced courtesy of the Alexander Turnbull Library

12 Sir Julien Cahn's Team v. New Zealand, Official Programme Printed Ephemera Collection, Courtesy of New Zealand Cricket Museum.

13 'Timetable of Conquest', The Press 24 March 1939, p 13, Image reproduced courtesy of the Alexander Turnbull Library. 


\section{Introduction}

This thesis explores the impact on New Zealand of a series of tours to New Zealand by foreign cricket teams in the 1930s. Eight teams visited during the decade. The Marylebone Cricket Club visited four times in 1929-30, 1932-33, 1935-36 and 193637. ${ }^{1}$ In addition, there was the first ever visits by a West Indian team in 1931 and a South African team in 1932, the England Women's team in 1935 and the Julien Cahn XI in 1939. These tours had social ramifications beyond the confines of cricket and New Zealand. They heralded a broadening of world sports generally, while the visitors themselves indicated the changing social realities and complexities of that decade. The matches were played on sports fields while the implications of each tour were thrashed out in the press, by cricketing boards, and in conversations by New Zealanders and cricketing tourists alike. The tours and surrounding reactions, debates and narratives occurred within broader conversations about nationhood, race, gender, the role of sport in society and Empire. The tours are of historical significance because they were major events of their day and of interest to the public at large. They are of value to historians as they provide another angle on conversations about contemporary society, culture and politics.

Sport matters in both the telling and creation of history. In the 1930s sport, and especially cricket, was a means of advancing the political and social claims of nonwhite West Indians; of conducting the robust though often neglected trans-Tasman relationship; and was a means of confirming the complexities of class relationship in England. ${ }^{2}$ The 1930 s is of special significance because of the changes which took place in international cricket (as well as sport in general) and because of the dynamic state of imperial relations within this decade. The West Indies, New Zealand and India gained Test status which lead to a growth in the number of international tours

\footnotetext{
${ }^{1}$ The Marylebone Cricket Club is both a sporting team and administrative body. During the 1930s and for much of cricket's history, the MCC has been a major force in the game's governorship. The MCC selected the England sides for Test series outside of England until the 1970s. MCC sides to New Zealand were not only an England selection but also a team representing the upholders of the laws and spirit of the game. The membership of the MCC were (and are) predominantly members of Britain's aristocratic or upper-classes, who also provided many of the amateur cricketers who played for the Club.

${ }^{2}$ See C.L. R. James, Beyond the Boundary, London, 1963 (2005); Philippa Mein Smith, The Tasman World' \& Charlotte Macdonald, ' Ways of Belonging: Sporting Spaces in New Zealand History' both in Giselle Byrnes (ed.), The New Oxford History of New Zealand, Melbourne, 2009; Richard Holt, Sport and the British, Oxford, 1989.
} 
undertaken, though not to an expansion beyond the existing countries and regions that already played. This was a decade, though, where sport in general became more global and more associated than ever before with entertainment on a world-wide scale as well as national and international politics. It is the decade of the Los Angeles (1932) and Berlin Olympics (1936) and of extensive radio and film coverage of major sporting events. ${ }^{3}$ Though cricket was influenced by the technologies and wider circumstances that boosted other sports like football, it remained the sport of the Empire rather than a global phenomenon. This study's examination of cricketing tours to New Zealand explores what being the 'sport of Empire' meant in a decade characterized by worldwide economic collapse, political and social unrest, imperial anxiety and decline into world war. New Zealand was developing its own unique place in the world, but this was not at the expense of its cherished associations with Britain. The cricket tours were sports ventures but also about New Zealanders celebrating and acknowledging their British cultural identity.

Cricket was played in New Zealand in the interwar years with enthusiasm. Tours were welcomed but New Zealand teams also began to tour England with visits in 1927, 1931 and 1937. The game was important to New Zealanders by virtue of the fact that people played the game and many put huge effort into the administration and preparation for each season. It was also significant because of the sport's strong cultural links to Great Britain, in a time when England itself was still often referred to as 'home'. Stuart Ward notes, 'cricket was the archetypal "imperial game", embodying the values and ethos of the British Empire abroad, which in turn reinforced a particular vision of England at home. ${ }^{4}$ Mike Cronin and Richard Holt conclude that 'cricket was widely held to embody the authority of the English gentleman, whose paternalism would guarantee both domestic and imperial harmony. This vision of a benign hierarchy rooted in English rural tradition and extending around the imperial world gave cricket a unique prestige and authority among English sports in the first half of the twentieth century. ${ }^{5}$

\footnotetext{
${ }^{3}$ Barbara Keys, Globalizing Sport: National Rivalry and International Community in the 1930s, Cambridge, 2006.

${ }^{4}$ Stuart Ward, 'Introduction' in Stuart Ward (ed.), British Culture and the End of Empire, Manchester \& New York, 2001, p. 14.

${ }^{5}$ Mike Cronin and Richard Holt, 'The Imperial Game in Crisis: English Cricket and Decolonisation’ in Stuart Ward (ed.), British Culture and the End of Empire, p. 112.
} 
A key facet of this thesis is to reflect on what was happening to imperial bonds and Empire in the 1930s and how the tours to New Zealand reveal aspects of the changing relationship. The most important contact was that between New Zealand and England. Cricket is intrinsically an English game within Britain. It is not so much a game of the Welsh, Scottish or Irish but a manifest part of Englishness and English culture. Throughout the Empire, though, the notions of Englishness and Britishness are more malleable and that is reflected in these cricket tours. When English cricket teams came to New Zealand, they represented England, certainly, but within the context of being part of Britain and a representation of British identity within the Empire. There were certainly people in New Zealand who identified themselves as specifically English, but more common was the perception of being 'British' was not at odds with also being a New Zealander. Therefore, the game was understood as English, but played by the British people of the Empire.

Cricket tours by New Zealand, English and other imperial teams were part of the broader popular cultural exchange within Empire that helped sustain and enrich the relationships amongst a wider 'British world'. John Mackenzie and Andrew Thompson are among those who argue that cultural aspects of Empire flowered in the interwar years. Cricket was one of those blooms. Thompson suggests that:

Far from being a period of popular disillusionment with empire, if anything the interwar years witness a deeper cultural penetration of imperial ideals. Post-war propaganda for the British Empire was bolstered by new institutions (like the Empire Marketing Board) and new media (radio, film) and it is in the 1920s that the apogee of mass phenomena of empire (shopping weeks, empire advertising, empire exhibitions, and Empire Day celebrations) is to be found. ${ }^{6}$

Events such as cricket tours were shared experiences that enabled people in New Zealand to celebrate both being a New Zealander and also being part of the British Empire. Cinema and radio such as the BBC World and Empire Service further fostered positive images of Empire not only to Britain but also around the Empire. ${ }^{7}$

\footnotetext{
${ }^{6}$ Andrew Thompson, Imperial Britain, The Empire in British Politics c. 1880-1932, Harlow, 2000, pp. 183-184. ${ }^{7}$ John Mackenzie 'The Persistence of Empire in Metropolitan Culture' Stuart Ward (ed.), British Culture at the end of Empire, pp. 21-36 and John Mackenzie 'The Popular Culture of Empire in Britain', Oxford History of the British Empire, The Twentieth Century, Oxford, 1999, pp. 212-231.
} 
Therefore as noted by Charlotte Macdonald, Jack Lovelock's 1500 metre win in Berlin was contextualised as one of victory for Empire as well as New Zealand. ${ }^{8}$

The eight tours of New Zealand by visiting cricketing sides in the 1930s were major events in the social calendar of the Dominion. There was much contemporary curiosity and excitement in advance of each visit; evaluation and consideration during the days and weeks of the tour; that continued well after each side had left New Zealand's shores. Although much has been written about cricket in New Zealand, there have been few works that look beyond the game itself, and certainly there is little that considers the tours within the wider context of Empire in the 1930s. New Zealand sports writers have provided detailed accounts of games and tours, with an emphasis on statistics and match records in the case of T. W. Reese's New Zealand Cricket 1841-1914 and New Zealand Cricket 1914-1933, or players, matches and venues in the authoritative work of Don Neely, Richard King and Francis Payne's Men in White, Lynn McConnell and Ian Smith's New Zealand Cricket Encyclopedia and Gerry Cotter's England versus New Zealand amongst other titles. ${ }^{9}$ Greg Ryan's The Making of New Zealand Cricket 1832-1914, is an analytical work based in deeper research. Ryan looks beyond the matches to investigate the particular nature and development of New Zealand cricket before World War One. Ryan has also contributed journal articles that investigate the nature of New Zealand cricket, in both the interwar years and post-World War Two periods, which are invaluable sources and historiographical context for this work. ${ }^{10}$ J. P. Carr's 2001 MA thesis 'The First Golden Age? A Social History of New Zealand Cricket 1914-39', investigates the grassroots and first-class intrigue in New Zealand cricket in the early twentieth century. One chapter details the imperial connection with England and Australia with a focus both the tours to New Zealand

\footnotetext{
${ }^{8}$ Charlotte Macdonald, 'Ways of Belonging: Sporting Spaces in New Zealand History', p. 283.

${ }^{9}$ T. W. Reese, New Zealand Cricket 1841-1914, Christchurch, 1927; T.W. Reese, New Zealand Cricket 19141933, Auckland, 1936; D. O. Neely, R. P. King, F. K. Payne, Men in White, The History of New Zealand International Cricket 1894-1985, Auckland, 1986; D. O. \& P. W. Neely, The Summer Game, Auckland, 1994; L. McConnell \& I. Smith, The Shell New Zealand Cricket Encyclopaedia, Auckland, 1993; Gerry Cotter, England versus New Zealand, Marlborough, Wiltshire, 1990.

${ }^{10}$ Greg Ryan, The Making of New Zealand Cricket 1832-1914, London, 2004; Greg Ryan, "Extravagance of Thought and Feeling': New Zealand Reactions to the 1932/33 Bodyline Controversy', Sporting Traditions, vol. 13, no. 2, May 1997, pp. 41-58; Greg Ryan, "Britishers Anxious to Appear on the Cricket Map' Anglo-New Zealand Cricket in the Imperial Context 1927-58', The International Journal of the History of Sport, vol. 25, no. 1, January 2008, pp. 18-40.
} 
but also New Zealand tours overseas. ${ }^{11}$ This thesis, 'Confirming Tradition, Confirming Change, explores cricket in a point and place of interaction between New Zealand and other parts of the world. It will look to place tours of visiting international teams beyond a New Zealand context, and will examine what cricket has to say in the broader imperial framework. The tours to New Zealand were not simply a series of matches played, but were a two-way conversation about cultural assumptions and understandings between peoples from around the Empire. The tours were not only events in New Zealand but moments when New Zealand became a focus of wider attention in the British Empire.

For the English sides that visited New Zealand, the cricket tours were a great adventure, a chance to play cricket in an exotic location and a chance to escape the English winter. They were also occasions that confirmed the bonds of Empire through playing the game and through associated social functions and other events. For the other teams that visited, the South Africans and the West Indies, the tours offered an opportunity to participate in an enjoyable aspect of their imperial legacy. The South Africans also had a strong sporting bond with New Zealand through rugby. The cricket tours extended this rivalry. The West Indies team's visit was very short but their commitment to the match in Wellington, just hours after arriving from the Caribbean, showed a determination to prove themselves worthy of their recently acquired Test status.

While the prestige and traditions of cricket are borne out in the deference that New Zealand teams displayed towards English cricketers on tour, they only reflect part of the narrative of 1930 s cricket. $^{12}$ The tours to New Zealand also demonstrate the changing nature of international cricket as well as relationships within the British Empire at that time. Prior to the 1930s, tours of visiting cricket teams to New Zealand were either from English teams whose players were predominantly selected from Oxbridge-educated amateurs, or Australian state or national selection teams. By contrast, the first three of the eight tours to New Zealand in the 1930s were

\footnotetext{
${ }^{11}$ J. P. Carr, 'The First Golden Age? A Social History of New Zealand Cricket 1914-39', MA Thesis, University of Canterbury, 2001. Due to the Christchurch earthquakes in 2010 and 2011 access to the only publicly available copy of the thesis has been limited.

${ }^{12}$ Greg Ryan, The Making of New Zealand Cricket 1832-1914; Greg Ryan, "Britishers Anxious to Appear on the Cricket Map' Anglo-New Zealand Cricket in the Imperial Context 1927-58'; Greg Ryan, "Extravagance of Thought and Feeling': New Zealand Reactions to the 1932/33 Bodyline Controversy'.
} 
comprised of an MCC selection that included an Indian prince; the inaugural visits by a largely black West Indian side; and a partition era, white South African Test side. These tours were individually a series of matches played with imperial collegiality and in great spirit with their New Zealand hosts. Collectively they exemplify the broadening scope of international level non-white cricket and the reactions and attitudes to this development. The next two teams were captain Douglas Jardine's highly efficient and infamous MCC Bodyline side of 1932-33 and the inaugural visit by the England Women's team in 1934-35. ${ }^{13}$ Both teams were exemplars of English sporting power and were very popular, but they were tours that also displayed the friction in cricket between forces of tradition and the drive toward sporting modernity. The last three tours were the MCC of 1935-36, MCC 1936-37 and the Julien Cahn XI in 1938-39. These tours retained many characteristic features of previous visits by English sides such as amateur captains. They also indicate the pressures for change which existed within cricket and Empire towards the end of the decade. Issues of professionalism, the competitiveness of the modern game and questions about the purpose of such tours were visible in these last three visits.

Though the characteristics of all eight tours appear to suggest a radical departure or new paradigm for cricket it is important to note the continuity within the game at the time. Cricket was being played as a tradition enhancing feature of such schools as Wellington College and Wanganui Collegiate which emphasized the game's traditions and Englishness. ${ }^{14}$ Furthermore, although the sides that toured New Zealand in the decade were not just white, male and Oxbridge-educated, they still were often the largest proportion of the players involved in the tours. ${ }^{15}$

The interwar years have historically been seen as a period of imperial decline or transition as the influence of Britain waned while national aspirations rose. ${ }^{16}$ This

\footnotetext{
${ }^{13}$ Gerald M. D. Howat, 'Jardine, Douglas Robert (1900-1958)', Oxford Dictionary of National Biography, available from http://www.oxforddnb.com/index/34/101034158/; first published 2004; online edn., Jan 2011; accessed 21 June 2011.

${ }^{14}$ See Greg Ryan's chapter 'Perpetuating the Straight Bat: Cricket and the Schools, 1860-1914' in The Making of New Zealand Cricket for detail on the origins of New Zealand's replication of English public school system.

${ }^{15}$ For a list of tours to New Zealand see D. O. Neely et. al. Men in White, pp. 35-173.

${ }^{16}$ Andrew S. Thompson, Imperial Britain. The Empire in British Politics c. 1880-1932, pp. 165-166, Thompson simply states that this is the case. For discussion see Bernard Porter, The Lion's Share, A Short History of British Imperialism, 1850-1970, London \& New York, 1975, pp. 265-269; Robert Johnson, British Imperialism,

Basingstoke, 2003, pp. 149-165; Keith Sinclair, A History of New Zealand, Auckland, 1959 (1988), p. 282; Keith Sinclair, A Destiny Apart, New Zealand's Search for National Identity, Wellington, 1986.
} 
narrative, in the case of New Zealand, is signposted by acts of distinction and independence, notably the acknowledged sacrifices in World War One, being a signatory at Versailles, their support for engagement in the 1926 Balfour Agreement, its position taken at the League of Nations and the Statute of Westminster - though New Zealand would not ratify this Statute until after World War Two. Malcolm McKinnon concluded that:

It was possible in the late 1920s to envisage a slow but profound change in the character of the Empire: disarmament, the increased importance attached to the League, the recognition of the independence of the Dominions. Maybe a new international order was being born even if much opinion in New Zealand was still attached to the patterns of the old. ${ }^{17}$

New Zealand was not only spreading its wings on an international stage but also flourished within. The interwar years were a period of growth for the alternative intellectual sub-culture of New Zealand. ${ }^{18}$ The 1930s artistic scene was:

dominated by the desire to bring into being a national consciousness: literature and the arts were seen as the means of representing that consciousness struggling to be born. The crucial expression of this effort to formulate such a consciousness was carried through in the thirties and forties in the work of a group of writers and painters such as Allen Curnow, Denis Glover, Charles Brasch, and Leo Bensemann, all associated with the Caxton Press, established by Glover in Christchurch in 1936, who set about overcoming the colonial sense of distance, isolation and inferiority by establishing a distinctive local literary tradition. ${ }^{19}$

Such aspirations, along with the relative independence of the Labour Government's foreign policy; the success of distinctly New Zealand icons such as the All Blacks, who won 14 of their 22 Test matches played in the 1930s, provide evidence of the

\footnotetext{
${ }^{17}$ Malcolm McKinnon, 'New Zealand in the World', Keith Sinclair (ed.), The Oxford History of New Zealand, Auckland, 1990, p. 247, W. David McIntyre, 'When, if ever, did New Zealand become independent?', The Jim Gardner Lecture 2002, The Canterbury History Foundation, 2002.

${ }^{18}$ Jock Phillips. 'Culture and recreation in the city - City culture, 1900-1965', Te Ara - the Encyclopedia of New Zealand, available from http://www.TeAra.govt.nz/en/culture-and-recreation-in-the-city/6; 5 Mar 2010; accessed 21 Dec. 2010; see also Keith Sinclair, A History of New Zealand, Auckland, 1959 (1988), pp. 280-282.

Addressing this Keith Sinclair, A Destiny Apart, New Zealand's Search for National Identity, pp.239-254; W. H. Oliver, 'The Awakening Imagination, 1940-1980', W. H. Oliver with B. R. Williams (ed.), The Oxford History of New Zealand, Oxford, 1981, (1984).

${ }^{19}$ Jenny Bornholt, Gregory O'Brien \& Mark Williams 'Introduction', Jenny Bornholt, Gregory O'Brien \& Mark Williams (ed.), An Anthology of New Zealand Poetry in English, Auckland, 1997, pp. xxv-xxvi.
} 
emergence of a genuine contemporary voice and identity in the later part of the 1930s.

The relationship with Britain was at times strained, though never enough to suggest New Zealand did not have absolute loyalty when faced with the threat of war. ${ }^{20}$ Arguably too much is made of New Zealand independence at this period, particularly with the notion that it surpassed its engagement with Empire. ${ }^{21}$ The importance of Empire and the emergence of nationhood were essentially mutually inclusive as New Zealand's economy and defence was reliant on the Empire, and the Empire was reliant on strong ties with its member nations - good cricketing relations were certainly part of maintaining these mutually beneficial relationships.

Race is a key theme of the thesis. The non-white cricketers in the touring teams were given a status above non-cricketers of the same ethnicity during their stay in New Zealand. What is interesting is the extent to which their acceptance by the New Zealand press and public was due to their prowess as cricketers and their status within the Empire. Also of interest is how the enthusiasm accorded to these players, notably Learie Constantine and Kumar Shri Duleepsinhji, compared and contrasted to white New Zealand attitudes to Maori sportsmen and the popular notions of Maori Aryanism in the interwar years. ${ }^{22}$

The game of cricket has been a means of defining Englishness and whiteness within the Empire. It is suggested by Jack Williams in Cricket and Race, that before World War One the game had been synonymous with white English identity and was regarded as an essential aspect of how the English, particularly the English elite, perceived themselves and wanted others to perceive them. Williams argues that cricket personified the very English traits that made the English superior and hence

\footnotetext{
${ }^{20}$ Philippa Mein Smith, A Concise History of New Zealand, Melbourne, 2005, pp. 159-160; Malcolm McKinnon, 'New Zealand in the World', in Keith Sinclair (ed.), The Oxford Illustrated History of New Zealand, pp. 250-252.

${ }^{21}$ David Capie has suggested that New Zealand history has been too heavily focused on a nation state narrative which has ignored external forces and trends. He argues, from the point of view of a historian of New Zealand diplomacy and international relations that 'diplomatic history reveals an important part of New Zealand's historical experience but an exclusive focus on the nation state blinkers as well as informs our view of the past.', David Capie, 'New Zealand and the World: Imperial, International and Global Relations', Giselle Byrnes (ed.), New Oxford History of New Zealand, pp. 573-576; James Belich in Paradise Reforged counters the notion of growing independence and argues that New Zealand and Britain re-integrated both culturally and economically after a period of divergence and that in effect Britain re-colonised New Zealand until the 1970s. James Belich, Paradise Reforged, Auckland, 2001.

${ }^{22}$ Origins of Maori Aryanism see Keith Sinclair, A Destiny Apart, pp.198-200.
} 
justifiable imperialists. They were thus, by default, racially superior to those over whom they ruled. ${ }^{23}$ He does though suggest that such views had altered and though there was racial prejudice between the wars in England, this was less evident in cricket than in other aspects of life. ${ }^{24}$ The two most famous non-white cricketers to visit New Zealand in the interwar year were Learie Constantine and Kumar Shri Duleepsinhji, both given a status above other people of colour within the Empire, though this may not have applied to all non-white cricketers. Patrick F. McDevitt suggests that:

Before WW2, an English MCC tour to the West Indies resembled a benevolent missionary effort beyond the bounds of civilization where natives needed enlightenment and instruction. Like most missionaries, the English cricketers believed they had nothing to learn from the West Indies, and treated their hosts with at best paternalism and at worst with outright disdain. ${ }^{25}$

Such racial attitudes were developed in the later nineteenth century and were sustained into the interwar period. The fear of non-whites within the imperial context were, according to Marilyn Lake and Henry Reynolds, largely fed by the collective success of various studies and accounts of the negative impact of multiracialism. Amongst the titles that were seized upon within the Anglo-Saxon world were Charles Pearson's National Life and Character - a Forecast, James Bryce's The American Commonwealth and later Lothrop Stoddard's 1920 publication The Rising Tide of Colour against White World Supremacy. Each confirmed the danger of non-white races gaining a foothold in 'white man's country'. ${ }^{26}$ This anxiety was clear to see in the legislation that was passed in New Zealand. In the late nineteenth century the colony had sanctioned a series of legislative moves restricting Chinese migration. In August 1920, the government introduced the Immigration Restriction Bill which greatly reduced the possibility of entry into New Zealand for non-whites. ${ }^{27}$ James Bennett, when discussing Maori in relation to this legislation, suggests that New Zealand's policy essentially mirrors the more infamous White Australia Policy, and was influenced by the close Trans-

\footnotetext{
${ }^{23}$ Jack Williams, Cricket and Race, Oxford, 2001, pp. 1-33.

${ }^{24}$ Ibid. p. 34.

${ }^{25}$ Patrick F. McDevitt, May the Best Man Win, Sport, Masculinity and Nationalism in Great Britain and the Empire 1880-1935, Basingstoke, 2004, p. 111.

${ }^{26}$ Marilyn Lake and Henry Reynolds, Drawing the Global Colour Line, Melbourne, 2008.

${ }^{27}$ Immigration Restriction Amendment Act 1920.
} 
Tasman connections and racial solidarity. ${ }^{28}$ Cricket at this stage does not wholly encompass such racial attitudes despite McDevitt's findings. Non-white sportsmen clearly identify with and adopt the game and are generally accepted into multi-racial sides, though there are moments of racism experienced. Cricket may have been synonymous with Englishness for an elite English minority but it was seen by both the white and non-white members of the Empire as a symbol of collective Empirewide identity, national pride in the case of Australia, and racial and regional solidarity in the case of the West Indies.

The West Indies team that came to New Zealand in 1931 and the Indian prince Duleepsinhji who came with the MCC in 1930, arrived at a time when not only was it difficult for non-white people to gain entry into New Zealand, but those who had gained residence were often treated poorly. In contrast to non-white migrants of the time, these men were treated as equals and even as sporting heroes by the New Zealand public. They were not the first non-white sportsmen to visit the country. A Fijian cricket team toured in 1895, a Chinese soccer team in 1924, and Indian hockey teams visited in 1926, 1935 and 1936. ${ }^{29}$ These athletes all came to New Zealand and played in games against New Zealand opponents in matches that were played in good spirit and celebrated as examples of imperial solidarity. Geoff Watson suggests that in the case of the hockey team they were accepted by the New Zealand public because they were from the elite of society and in the case of the 1926 side largely from the ranks of the Indian Army who had fought alongside the New Zealand forces in World War One. ${ }^{30}$ In the case of the West Indian team, they were not perceived as an economic threat to New Zealanders and their stay was but a short one. ${ }^{31}$ Despite the clear racism inherent within New Zealand's immigration laws, the fact that New Zealand was allowing entry to the country and was happy to play against, and indeed warmly receive non-white members of Britain's Empire, indicates the privileged place sport held in society.

\footnotetext{
${ }^{28}$ James Bennett, 'Maori as Honorary Members of the White Tribe', The Journal of Imperial and Commonwealth History, Vol. 29, no. 3, 2001, pp. 34-35.

${ }^{29}$ Fiji team included at least 6 ethnic Fijians, while the rest were English or Australian born cricketers.

${ }^{30}$ Geoff Watson, 'Affirming Indian Identities? An Analysis of Imperial Rhetoric and Orientalism in the tour of Indian Hockey Teams to New Zealand in 1926, 1935 and 1938’, Sporting Traditions, Vol. 21, no. 2 (May 2005), pp. 127-128.

${ }^{31}$ Andrew Honey, Sports, 'Immigration Restriction and Race - The Operation of the White Australia Policy', Ricahrd Cashman, John O'Hara, Andrew Honey (ed.), Sport Federation Nation, Sydney, 2001, p. 46. Honey is discussing the West Indies in Australia but his argument also applies to New Zealanders.
} 
The term 'British race' was commonly used in the interwar years yet and was not simply applied to the English speaking Anglo-Saxon and Celtic people of the Empire but could also include Maori within a broader concept of the term. ${ }^{32}$ It was not a fixed term but one that shifted dependant on situation and context. Cricket is an aspect of British culture where this ambiguity is most evident, but this is not to say sport itself at the time was not racially charged. The 1930s was a period of sporting globalisation where people of various ethnic groups competed against each other in sports previously only contested by a white population. John Hoberman in Darwin's Athletes states that 'the evidence shows that the globalization of modern sport has brought about a simultaneous globalization of racial folklore about athletic performance, ${ }^{33}$. This folklore manifests itself as a perception of physical difference between white and non-white and a narrative of black athletic superiority was linked to a perceived primitivism. This construct was of the white imagination striving to maintain control by defining differences in people and the racial superiority of white people. $^{34}$

Hoberman's argument is primarily focused on African-American sportsmen, their dominance of American games and the commercialism of American sport. The enthusiasm of a white public for the spectacle of non-white sportsmen is certainly manifest in cricket, but the notion of racial superiority and commercial exploitation is less clear. Commercialism did not sit well with cricketing aristocracy but there was certainly a commercial element to cricket within England at the time. ${ }^{35}$ This is particularly in the case of the Lancashire league in which Learie Constantine, the great black West Indian all-rounder, was a professional for Nelson from 1929-1937 and a great draw-card. His ability, dominance and difference at a time when nonwhite cricketers were a rare sight in the North of England meant huge crowds came to watch him play. Almost half the gate receipts of the whole Lancashire League were taken at matches in which Constantine was a player. ${ }^{36}$ People clearly came to

\footnotetext{
${ }^{32}$ See James Belich, Paradise Reforged, pp. 206-210; also James Bennett, 'Maori as Honorary Members of the White Tribe'.

33 John Hoberman, Darwin's Athletes, Boston, 1997, p. 138.

${ }^{34}$ Ibid. pp. 146-147.

${ }^{35}$ See Derek Birley, A Social History of English Cricket, London, 1999; Jack Williams, Chapter 8 'Cricket and Commercialization' in Cricket and England, London, 1999.

${ }^{36}$ Jack Williams, Cricket and England, p. 64. Williams notes his other work on League cricket, J. A. Williams, Cricket and Society in Bolton, with specific reference pp. 224-230 and 258-263.
} 
watch him because he was a brilliant cricketer and a star of the game, but part of his appeal and drawing power was simply that he was different. The press reaction in New Zealand to Constantine is one of curiosity and delight.

The tours to New Zealand also provide an opportunity to investigate the issue of gender and sport within the context of the interwar years. The England women's cricket team visited New Zealand in 1935. It was the first international female cricket tour in a game that is traditionally a male enclave. British sport at the time was, as Patrick McDevitt notes, 'a means for disseminating British ideals of masculinity around which colonial subjects could mobilize. ${ }^{37}$ Cricket, like other sports, provides a means of identifying with a particular cultural grouping and social norms and the arrival of a high profile women's cricket team was a departure from those norms. The team was welcomed and warmly received by the New Zealand public, but it was their appearance which generated as much interest as their capacity to play an inch-perfect forward defensive stroke. Although conservatively dressed, attention paid to their style of clothing, hairstyles and marital status far outstripped that shown in the sportsmen. Richard Cashman notes that 'while there has been very limited interest in the sexual activities and partners of males off the field, there has been much discussion (largely off the record) of these matters about sportswomen. A press remark, in the 1930s, that 'English cricketer Betty Archdale's hair was cropped close in the style of a boy must have been enough to set some male tongues wagging., ${ }^{38}$ The tour reveals examples of both stereotyping female cricket players as masculine, and of occasions on which promotion of their appearance exceeds promotion of their ability as cricketers. Such reaction is perhaps unsurprising because of the long established notion of masculinity in cricket perpetuated by school sporting curricula and press attitudes, but this only tells half the story.

The tour also occurred at a time of growing female sporting participation that was particularly observed in the Empire and Olympic Games. The increase in numbers of sportswomen stimulated debates about the appropriateness of women's sport both in terms of clothing and physiology. ${ }^{39}$ It also exemplified the confidence and attitude of

\footnotetext{
${ }^{37}$ Patrick F. McDevitt, May the Best Man Win, p. 4.

${ }^{38}$ Richard Cashman, Paradise of Sport, Oxford, 1995, p. 81.

${ }^{39}$ Early pioneers Gloria Minoprio (Golf), Suzanne Lenglen (Tennis), Jennifer Hargreaves, Sporting Females, Critical Issues in the History and Sociology of Women's Sports, London \& New York, 1994, pp. 116-117, 134.
} 
a growing middle-class at a time of gradual legal and economic emancipation and the team itself was linked to the successful suffrage campaign in Britain, as the captain of the side, Betty Archdale's mother was a prominent suffragette. ${ }^{40} \mathrm{New}$ Zealand had voted in its first women Member of Parliament, Elizabeth McCombs in 1933 providing a moment of optimism and advancement for women at a time in which women had in many regards borne the brunt of the Depression. ${ }^{41}$ The growth of women's cricket can be seen as an extension of opportunities in sport for women of sufficient wealth and ability.

The England women's tour, while it represented the new sporting opportunities available to women, was in itself a continuation of the imperial attitudes and assumptions that underpinned men's sport - that the British Empire worked because it was run by the British race who were inherently better suited to run the Empire than other races. The 'lady cricketers' therefore represented something of a conundrum as they were, on the one hand, an active force in the new international female sporting movement; while on the other, they represented a conservative ethic within the British imperial context.

Of the eight tours to New Zealand six were by teams from England with four of those by the MCC. The MCC, as an organisation and as a touring party, provided the benchmark for cricketing mores and principles. New Zealand cricket followed the sporting advice of the MCC unwaveringly in the 1930s. As Greg Ryan notes, New Zealand cricket had always 'lingered within a passive imperial ideology and preoccupation which stressed form and convention ahead of success. ${ }^{42}$ Those conventions were set by the MCC who were seen as a potent symbol of the success of Empire and the transnational appeal of English cultural forms. New Zealand could share in this because of the two countries' mutual heritage. The tours have value as areas of research because they are such concentrated examples of the imperial connection in a decade where both the nature of sport and Empire were being altered by a growing sense of nationalism and the popularity of sporting contests.

\footnotetext{
${ }^{40}$ Archdale's mother was Helen Alexander Archdale (née Russel), David Doughan, 'Archdale. Helen Alexander (1876-1949)', ODNB available from, http://www.oxforddnb.com/index/101058331/Helen-Archdale; first published 2004; accessed March 2011.

${ }^{41}$ Philippa Mein Smith, A Concise History of New Zealand, p. 153.

${ }^{42}$ Greg Ryan, 'New Zealand', Brian Stoddart \& Keith Sandiford (ed.), The Imperial Game, Manchester, 1998, p. 104.
} 
Cricket has been a source of academic interest because of the game's part in building and nourishing Empire, racial, national and gender identity. Much of this research has centered on cricket's assumed 'golden period' of the late Victorian-Edwardian age. There is a consensus amongst historians that cricket was rapidly adopted by the Victorians as a means of developing and expressing manliness, athleticism, a particular moral vision and entrenching class differences. ${ }^{43}$ The game was inextricably tied to 'muscular' Christianity and associated with British imperial ambition and the cult of athleticism that was taught through the major public schools such as Eton and Harrow and the universities of Oxford and Cambridge. ${ }^{44}$ Cricket, and the other games adopted by the Victorians and continued into the Edwardian Age, were part of a games ethic: a belief in the power of sport to prove British prowess. James Mangan concludes that 'subscription to the games ethic was not merely the derivative source of sacrifice; it was the manifestation of the moral supremacy of white Motherland and her Dominions over black, brown and yellow 'races' and ultimately over the Kaiser's Germany. ${ }^{45}$ The game came to the colonies with migrants and missionaries and was developed through the school system. It was first recorded in New Zealand by Charles Darwin who observed a game being played by Maori and missionary children in 1835 at a mission station in the Bay of Islands. ${ }^{46}$ The game's Victorian values were entrenched in New Zealand through the large number of Oxbridge graduates who migrated to the colony (particularly to Christchurch). ${ }^{47}$ The game's development, though hampered by financial and geographic factors, was nevertheless a cherished aspect of New Zealand sporting endeavour before the First World War. As Greg Ryan states, there was a close association 'between the administration of New Zealand cricket and the political and economic elite of the colony, with the result that the game never lacked for articulate appreciation of its wider implications. ${ }^{48}$ Given this association, one can understand why tours to New Zealand by English sides were heralded as great moments in the

\footnotetext{
${ }^{43}$ For example James Mangan, The Games Ethic and Imperialism, Harmondsworth, 1986; Richard Holt, Sport and the British; Keith Sandiford, Cricket and the Victorians, Aldershot, 1994, et. al.

${ }^{44}$ Keith Sandiford, Cricket and the Victorians, pp. 2-49; Keith Sandiford, 'England' in Brian Stoddart \& Keith Sandiford (ed.), The Imperial Game, pp. 9-29; see also Timothy J. L, Chandler, 'Games at Oxbridge and the Public Schools 1830-1880 - 'The Diffusion of an Innovation' in International Journal of the History of Sport, Vol. 8, No. 2, 1991, pp. 171-199.

45 James Mangan, The Games Ethic and Imperialism, p. 51.

${ }^{46}$ D. O. Neely, Men in White, p. 23.

${ }^{47}$ Greg Ryan, ‘New Zealand', pp. 94-96.

${ }^{48}$ Ibid, p. 94.
} 
life of the colony. For the colonial elite it was an opportunity to connect with members of their own class, which constituted the majority of the players in the touring sides. For the New Zealand public at large, the visit by a touring team was a chance to witness those high quality cricketers whom they only knew by reputation from press reports. Much of this was still the case in the 1930s. However, the impact of the First World War upon Victorian-Edwardian values, class distinctions and the very meaning of the Empire itself, meant that tours to New Zealand in the 1930s (as well as the interwar period in general) were often moments of tension between imperial sporting legacy and the newer realities of Dominion ascendancy, a greater sense of nationhood, globalisation and sporting professionalism.

The horrors of the First World War had a impact on the jingoism and class structure of the Empire. ${ }^{49}$ The games cult, endemic in British sport before the war, was increasingly criticised in the 1920s and 30s. It was associated with the naivety of military leaders and the futility of the Western Front campaigns. The captains and players that made up the teams who came to New Zealand were very much influenced by the war because they had either served in the military or had lived their formative years during the First World War. ${ }^{50}$ Patrick McDevitt argues that the mentality of English amateur cricket was affected by the horrors of warfare which had weakened the class order of pre-war England. He suggests, that in relation to Bodyline, the English tactic of bowling fast deliveries at Australian batsmen used in the Ashes series of 1932-33, was a manifest attempt to re-establish the position of the public school elite by the younger brothers of the officer class who had so prominently fought (and died) in the trenches. ${ }^{51}$ Derek Birley in A Social History of English Cricket comes to much the same conclusion. He argues that the MCC reaction to Bradman was to 'deploy its professional troops under a patrician leader post war variety - in defense of the established caste system. ${ }^{52}$ Jardine, though, was something of an exception. The MCC captains of the 1930s who visited New Zealand and Australia were genial, diplomatic and fostered imperial cordiality (at least publicly). Even Jardine himself in New Zealand was the consummate diplomat.

\footnotetext{
${ }^{49}$ Patrick F. McDevitt, May the Best Man Win, pp 84-85

${ }^{50}$ Ibid.

${ }^{51}$ Ibid.

${ }^{52}$ Derek Birley, A Social History of English Cricket, p. 234.
} 
The four MCC tours to New Zealand in the 1930s were for the visitors, about retaining bonds of Empire and less about class subjugation. Their sides to New Zealand in the decade were a mixture of amateurs and professionals, and while they retained the pre-eminence of amateurs as captains, there was not the same rigidity towards professionals that had been experienced in the past. The MCC side that visited New Zealand in 1929-30 was led by Harold Gilligan. He was at pains to show that their professionals were treated with respect and not simply as workers as had been the case on previous tours. ${ }^{53}$ The New Zealand Free Lance writer 'Touchline' noted:

Harold Gilligan the captain of the MCC team makes a strong feature of the fact that the men under his control are a team and not a collection of amateurs and professional cricketers. With the years the old dividing line between the amateur and the professional in cricket is disappearing and $\mathrm{New}$ Zealanders generally will be pleased with the statement made by the English captain. We in this part of the world could never understand why there should be such a marked distinction between the players. ${ }^{54}$

It is important not to overstate the notion of New Zealand as a promoter of the rights of professionals. There were few professionals in the New Zealand game because of the financial constraints in which the sport was played, as much as it being a matter of principle. In addition, those who did become professional players were often treated poorly. ${ }^{55}$ As we shall see, the debate about professionals is one that continued on in New Zealand cricket throughout the decade reflecting anxiety about how the game was being played in the country at large.

New Zealand cricket in the 1930s was generally balanced on a financial knife-edge. The vast majority of New Zealand first-class cricketers were amateur cricketers, but not in the English sense of amateur. ${ }^{56}$ They could only play cricket as a hobby while

\footnotetext{
${ }^{53}$ See Owen Mann, 'The Cultural Bond?' International Journal of the History of Sport, Vol 27, No 12, September 2010, pp. 2187-2209.

${ }^{54}$ New Zealand Free Lance, 18 December 1929, p. 47.

${ }^{55}$ Example: Ted Badcock who played for Wellington on talent alone, should have been selected for the tour of England in 1927. His place was removed because of the bias against professionals that was a lingering aspect of English cricketing mores in the New Zealand game. Badcock was born in England but had been playing for Wellington since 1924-25. See J. P. Carr, The First Golden Age? A Social History of New Zealand Cricket 1914-1939', p. 146. Carr references McConnell \& Smith, The Shell New Zealand Cricket Encyclopaedia, pp. 1415 and Neely et al, Men in White, p. 74.

${ }^{56}$ To be an amateur cricketer, up to and including the 1930s, meant you were often from a financially secure background and not hindered by the need to play the game for economic gain and instead could concentrate on
} 
maintaining a fulltime job. When touring sides were visiting during the New Zealand summer, first-class players, if selected, had to obtain leave from work in order to play in the Test and tour matches and domestic Plunket Shield. This obviously was not always possible, with the consequence that New Zealand cricket teams were often not able to field full-strength sides. ${ }^{57}$ Considering the lack of time that players could give to cricket and the small population base from which teams could be selected, it is remarkable how well New Zealand did in matches.

New Zealand made three financially fraught tours of England in 1927, 1931 and 1937. These tours, which were New Zealand cricket's first forays 'home', were also evidence of the changing nature of international cricket. Each of New Zealand's tours resulted in creditable results for the New Zealand sides, particularly in 1927. On that tour the team played 38 matches (26 of which were first-class matches), five were lost (all first-class) and 20 (14 first-class) were drawn. ${ }^{58}$ This team played particularly attractive cricket and was notable for six of the tourists scoring more than 1000 first class runs on the tour. These were Stewie Dempster, Roger Blunt, Tom Lowry, Jack Mills, "Curly" Page and Ces Dacre. ${ }^{59}$ As we shall see in the following chapters, matches against teams touring New Zealand were not as successful for the New Zealand team. Only draws and defeats were achieved in the Test matches, and the provincial sides had only limited success. Perhaps the starkest example of the gulf in ability between the established Test sides of world cricket and New Zealand was the match played at Eden Park in 1933 when New Zealand faced the might of Douglas Jardine's Ashes-winning England side in a three day test. New Zealand were bowled out for a paltry 158 (Stewie Dempster contributed 83 not out) and in reply England smashed 548-7 including a world-record 336 by Wally Hammond. Such was his control that his last hundred came in just 47 minutes. Rain robbed the match of the final day and probably a sizable England victory. ${ }^{60}$

Poor match performances have long been a reality in New Zealand cricket. This is one reason why rugby has taken precedence in the sporting story of national

maintaining the moral balance and sportsmanship of the game. See Jack Williams, 'Cricket', in Tony Mason (ed.) Sport in Britain - A Social History, Cambridge, 1989, pp. 119-120.

57 J. P. Carr, 'The First Golden Age? A Social History of New Zealand Cricket 1914-1939', p. 133.

58 D. Neely et al. Men in White, pp.74-97.

${ }^{59}$ D. Neely \& P. Neely, The Summer Game, p 107.

${ }^{60}$ D. Neely et al. Men in White, p. 134; D. Neely \& P. Neely, The Summer Game, p. 120. 
development. It is not surprising that Jock Phillips in A Man's Country, suggests that 'throughout the twentieth century, the New Zealand rugby team has served to personify and also reinforce the value system of New Zealand men'. ${ }^{61}$ The stark fact is that the national rugby team achieved far greater success than the New Zealand cricketers. Cricket remained a cherished sport, as attested by the large crowds who passed through the turnstile for much of the twentieth century. But, as rather bluntly put by James Belich, 'New Zealand cricket could not be the national game, because we did not win enough. ${ }^{62}$ For Greg Ryan, cricket lost its status in the national psyche to rugby around the beginning of the twentieth century. He states that this was not solely because of the success of the 1905 New Zealand rugby tour to Britain, as asserted by Jock Phillips, among others. Rather, there were many issues that would haunt the game of cricket in the following decades and which were apparent in the 1930s. These included the relative failure of the NZCC as an administrative body; wretched cricketing weather; and the difficulty of preparing acceptable grounds for play, along with (and not least) the psychological effect of depressingly poor results. ${ }^{63}$

New Zealand was granted Test status in 1930 having previously been given the right to send a delegate to the Imperial Cricket Conference in 1926, with the understanding that the country, along with the West Indies and India, were now ready to achieve Test status. Previously only England, Australia and South Africa had Test status and voting rights at such an influential conference. The choice of playing nations was, however, still very selective and power was retained within a tight circle of officials from the MCC and the ICC. Barbara Keys noted that 'almost everywhere in the twentieth century sports became an important way to instill a sense of belonging to a nation.' It also helped to solidify loyalty and 'a bond of attachment to an abstract entity'. ${ }^{64}$ In the case of cricket, this 'abstract entity' was not national identity so much as loyalty and association within the Empire.

\footnotetext{
${ }^{61}$ Jock Phillips, A Man's Country, Auckland, 1987, p. 108.

62 James Belich, Paradise Reforged, p. 373.

${ }^{63}$ Greg Ryan, The Making of New Zealand Cricket 1832-1914, particularly chapter seven, 'A Fragile Edifice:

The New Zealand Cricket Council 1894-1914', pp. 153-174.

${ }^{64}$ Barbara Keys, Global Sport, National Rivalry and International Community in the 1930s, p. 17.
} 
Each of the Test playing nations played within the context of being part of a bigger picture: one which was essentially hierarchical and controlled by an elite, proEmpire minority. In India, cricket in the 1930s was largely patronised by the Maharajas, who also enjoyed the prestige of being the captains of their sides. Richard Cashman draws the conclusion that Indian cricket of the 1930s parallels English cricket in the eighteenth century, when it was patronised by aristocrats and businessmen. ${ }^{65}$ Cricket provided a strategic and ideological link between the dependent Princes of Indian kingdoms and Britain and, metaphorically, helped 'underpin the Raj'. ${ }^{66}$ Cricket in the West Indies by the 1930s had been adopted by the various communities that inhabited the islands. These included the colonial white elite, the black West Indian majority as well as Indian and Chinese West Indians who took to the game. ${ }^{67}$ The West Indian cricket team included non-white players but was always led by white captains and, according to Hilary Beckles, the team was 'riddled with racism and class arrogance'. ${ }^{68}$ South African cricket during the interwar years reflected the social policies of the South African Government. This period in its history is referred to as the segregation era, a term which essentially meant that the Coloured, Malay, Indian and African peoples were disenfranchised from good land, decent workplaces and status in government. ${ }^{69}$ The national cricket team reflected this apartheid as it was predominantly composed of Anglo-South Africans, with the addition of some players of Dutch origin. South Africa's racial policy also determined the composition of their opponents as they did not play India or the West Indies until their re-admission to Test cricket in the 1990s.

Australia was the most powerful cricketing nation in playing terms in the 1930s. Richard Cashman describes the interwar years as the 'zenith' of Australian cricket. The boom, he concludes, was because of the rise of the game's greatest star Don Bradman, the nation-gripping nature of the infamous Bodyline series and the

\footnotetext{
${ }^{65}$ Richard Cashman, 'The Subcontinent', Brian Stoddart \& Keith Sandiford (ed.), The Imperial Game, Manchester, 1998, pp. 125-127; see also Ramachandra Guha, A Corner of a Foreign Field, London, 2002

${ }^{66}$ Richard Cashman, p. 122.

${ }^{67}$ Hilary Beckles, The Development of West Indies Cricket, Kingston, 1998, p. 149.

${ }^{68}$ Ibid p 51.

${ }^{69}$ Bruce Murray and Christopher Merrett, Caught Behind - Race and Politics in Springbok Cricket, Scottsville, 2004, pp. 29-30.
} 
popularity of the new ball-by ball broadcasting. ${ }^{70}$ The growth of cricket in Australia and the fact it became such a symbol of national identity and confidence, meant that cricket had come to symbolize national assertion alongside the existing imperial bonds. The Australian Board of Control (ABC) were certainly asserting their own needs rather than those of others when they essentially cut New Zealand adrift in the 1930s, neither officially touring nor accepting a major tour to New Zealand in the decade. Australia can be seen as the cricket-playing nation most attuned to the international sporting trends in this period, though this perception must be tempered by the fact they were still competing in and enmeshed within a British imperial world.

Australia did not send a cricket side to New Zealand in the 1930s but an Australian team that included Don Bradman did briefly stop in Wellington in 1932 when returning from North America. Former Australian Test player Arthur Mailey had organised a goodwill tour of Canada and the United States, and had assembled a strong side that included seven players of Test experience including Stan McCabe, Leslie 'Chuck' Fleetwood-Smith, Arthur Mailey and Viv Richardson alongside Bradman. The tour of North America was an extensive two month venture that took the team from Montreal to Los Angeles and incorporated Bradman's honeymoon. When the Australian side arrived in Wellington there was clearly great excitement, primarily reserved for Bradman. The Evening Post reported the arrival of the Australian side on the Monowai and when Bradman and his young wife appeared on the gangway there were outbursts of cheering:

Although he had never set foot in Wellington before this young man was no stranger; he was known by his deeds which have made him the most talked of man in the world of cricket. Mr and Mrs Bradman were escorted with difficulty through the waiting crowds and, once clear of the wharf sheds and the outer barrier, they were followed by hundreds of admirers of all ages, with budding youth predominant, down the Queen's Wharf and out into Jervois Quay, where a motor-car awaited them. ${ }^{71}$

\footnotetext{
${ }^{70}$ Richard Cashman, 'Cricket', Wray Vamplew \& Brian Stoddart (ed.), Sport in Australia - A Social History, Cambridge, 1994, p. 63.

${ }^{71}$ Evening Post, 19 September 1932, p. 9.
} 
The Australian side had agreed to play a one day exhibition match at the Basin Reserve, which was a wash-out, denying the large crowd that had gathered in the hope of seeing Bradman bat. Arrangements were made for a two hour hit the following day, just before the Monowai sailed. This went ahead in front of a large and curious party but they were again disappointed as Bradman failed to show - he was unaware that the short match had been organised and had taken a motor trip through the Hutt Valley to the Rimutakas. ${ }^{72}$

This very short visit by an Australia selection to New Zealand showed the warm and generous relationships between the players but the North American tour by the Australians confirms the difference in views between the ABC and the New Zealand Cricket Council. The ABC and Australian cricket were focussed on new markets and opportunities rather than propping up their small cricketing neighbour. ${ }^{73}$ That the $\mathrm{ABC}$ would sanction so many of its current players to partake in an extensive tour of a region where cricket was not a major sport yet would not organise a side of comparable strength to visit New Zealand in the decade is evidence of their attitude.

The granting of Test status, the growth of home and away tours, and the commencement of cricketing relations with South Africa and the West Indies, do however demonstrate the emergence of New Zealand into the cricket world. These developments led to a greater public awareness that 'Test' matches, by their nature, are competitions between nations. The tours placed New Zealand cricket within a broader imperial context, albeit one from which Australia is largely absent. This change in the paradigm, in which New Zealand began to define itself as a separate nation, (though one which remained closely aligned with the MCC), reflects both the greater imperial and national realities of the interwar years.

The thesis is arranged in three chapters which follow a chronological sequence. Each chapter is arranged and organised by an overarching theme or set of themes. Chapter One covers the first three tours of the decade: the MCC tour of 1929-30; the short West Indian tour in 1931; and the South African tour of 1932. These tours illustrate the ways in which international cricket was on the one hand an exemplar of broader

\footnotetext{
${ }^{72}$ Evening Post, 21 September 1932, p. 8.

${ }^{73}$ Greg Ryan, 'Kiwi or English? Cricket on the Margins of National Identity', Stephen Wagg (ed.), Cricket and National Identity in the Post Colonial Age, London \& New York, 2005, p. 30.
} 
racial sporting contact but also representative of the segregation and racism that was prevalent in the game and in the Empire. This chapter looks at the way race defined people in the period and how this was experienced through these cricketing tours to New Zealand. Chapter Two explores the MCC tour of 1932-33 and the England Women's side that visited New Zealand in 1934-35. These tours can be seen as a clash between modernity and nostalgia in cricket. Both teams were controversial to a degree and were clearly aspects of a new cricketing identity, but were also defined by their association with the past. This chapter explores the contradictions within the tours and how they were received by the New Zealand public. Chapter Three covers the last three tours of the decade and explores the difficulties, pleasures and contrasting motivations behind cricket tours to New Zealand. The three teams covered in this chapter are the MCC 1935-36 side, the MCC 1936-37 side and the Julien Cahn XI which visited New Zealand in the 1938-39 season. At that time, New Zealand was entering a period of greater international visibility while also gradually moving towards war. These tours exemplify the frustrations within cricket, most clearly the negative nature of matches and uncertainty about how professionalism should be managed. 


\section{Chapter One: New Visitors - Race and the Wider Imperial World - Duleepsinhji, the West Indies and South Africa visit, 1929-1932.}

The first three tours to New Zealand in the 1930s were undertaken by the MCC in 1929-30 (a side that included the acclaimed Indian-born batsman Kumar Shri Duleepsinhji), the full-strength and predominantly black West Indian side in 1931, which made a short visit before their maiden tour of Australia, and the South African team just a year later. The inclusion of India and the West Indies as Test nations in the ICC, and the addition of several Anglo-Indian cricketers in the England team, signposted a more racially diverse future for international cricket - while the South African team reflected the continued racial based exclusion within that country's sport that was tacitly accepted by the MCC and ICC.

This chapter discusses the fluid nature of race relations within the cricket world as evidenced by touring teams to New Zealand in the 1930s. Looking at contemporary sources, New Zealand's reaction to these three tours shows a degree of colour blindness. While newspaper coverage revelled in the visit of Duleepsinhji, the Indian batting star who played for England, and Learie Constantine, the great black West Indian all-rounder, there is evidence of less tolerance towards people of colour trying to live or work in New Zealand at the same time. The place of cricket within the Dominion, as a symbol of imperial solidarity and unity, meant that the non-white sportsmen were given an elevated status. In Duleepsinhji's case his obvious sporting abilities further enhanced the standing already established by his wealth and background. These two players were skilled cricketers whose abilities were a primary reason for the public interest. Like Bradman, Larwood and Hammond, three great white players of the 1930s, Duleepsinhji and Constantine provoked great interest and drew large audiences to games because of their towering achievements. ${ }^{1}$ Conversely, the South African tour confirms a white sporting solidarity that goes

\footnotetext{
${ }^{1}$ Harold Larwood was a great English fast bowler of the interwar years, who is associated with the Bodyline series of 1932-33. See Peter Wynne-Thomas, 'Larwood, Harold (1904-1995)', ODNB; available from http://www.oxforddnb.com/index/101058106/Harold-Larwood; first published 2004, online edn., Jan 2011; accessed May 2011; Walter Hammond was England's premier batsman of the interwar years. See Gerald M. D. Howat, 'Hammond, Walter Reginald (1903-1965)', ODNB; available from http://www.oxforddnb.com/index/101033674/Walter-Hammond; first published 2004; online edn., Jan 2011; accessed May 2011.
} 
beyond cricket. There was certainly no reference during the South African tour to the treatment of George Nepia, the All Black, or Duleepsinhji, both of whom had recently been left out of their respective sporting sides to face South Africa. Instead, the South African tour was principally about recognising the ties that bound the two former colonies. 


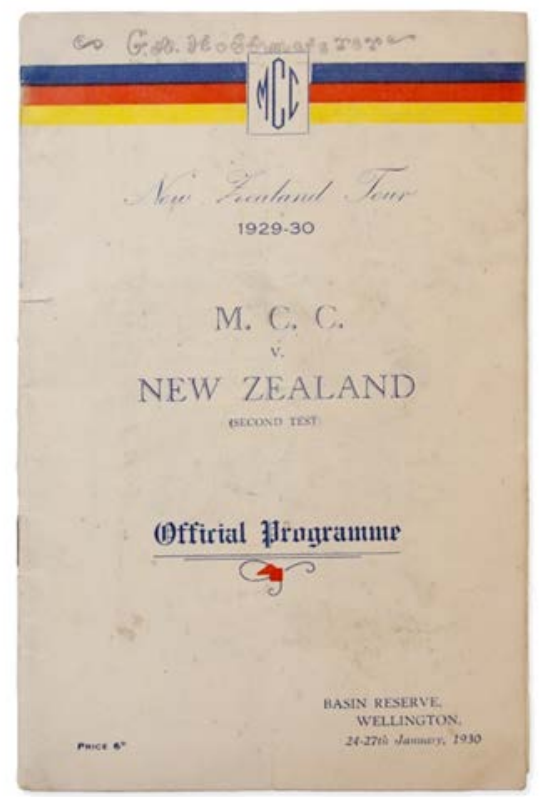

'MCC v New Zealand 1929-30',

Printed Ephemera Collection, Courtesy of New Zealand Cricket Museum

The MCC 1929-30

The MCC side of 1929-30 - the first team from England to tour New Zealand since 1922-23 - was not a full-strength England team, but was considered by the local press to have sufficient quality to provide good competition and interest. The team included six professionals in the party of 15 players, all of whom were established or developing first-class cricketers. It contained two genuine stars of the interwar years, the prolific batsman Frank Woolley and the Indian-born batting sensation Kumar Shri Duleepsinhji. The tour had an extensive schedule starting with five matches in Australia and 17 matches in New Zealand that included three Tests against New Zealand, matches against the major associations: Wellington, Auckland, Otago and Canterbury, and also encounters with minor associations including Rangitikei, Wairarapa and Nelson. ${ }^{2}$ The tourists went undefeated through New Zealand, though with some scares. The visit was conducted with the level of collegiality expected of

\footnotetext{
${ }^{2}$ This series was retrospectively given Test status when New Zealand toured England in 1931. The term Test match' had been used to describe international matches of different codes for matches in which New Zealand played English or Australian teams since the earliest tours, but the official designation only emerged later.
} 
such a tour, but the New Zealand public was also surprised by the apparent lack of pretension and class division within the tourist camp.

The New Zealand Cricket Council had regularly attempted to persuade the MCC to tour New Zealand, particularly if the English team were already scheduled to play in Australia, despite the considerable financial burden such tours could entail. Touring was expensive for the host. Partially due to New Zealand's unpredictable summers, previous tours had been detrimental to New Zealand cricket's limited financial reserves. For example, the MCC side of 1906-07 was projected to gross $£ 2,500$ but lost the NZCC nearly £600, achieving gate receipts of only $£ 1669 .^{3}$ The New Zealand team made its inaugural tour of England in 1927, which it was estimated required at least $£ 8000$ to break even. The New Zealand Cricket Limited public company was set up to sell 10,000 11 shares. ${ }^{4}$ When the MCC confirmed they were sending a team to New Zealand in late 1929, the NZCC were emphatic that a touring team must contain players who would draw a crowd as well as being 'the right kind of chaps' who would provide the technical and attitudinal example for local players to follow. The MCC originally listed a team that, although capable, seemingly lacked the drawcards, leading to a forthright telegram from New Zealand to MCC headquarters:

...essential your personel [sic] should approximately protect us against loss STOP could you substitute in your suggested team say Duleepsinhji and Woolley and or Hendren for less known players STOP we appreciate your past generosity and consideration but our present finances prohibits our taking risk STOP if you cannot obtain team to suit would prefer postponement to more favourable year STOP we would bear cost including passages from commencement except professionals fees such fees repayable out of profits. ${ }^{5}$

The MCC acquiesced to the demands, persuading Frank Woolley and Kumar Shri Duleepsinhji to join the tour thus providing the names that the NZCC desired to make the tour viable. The NZCC sent a brief but excited cable:

\footnotetext{
${ }^{3}$ NZCC, Annual Report 1907 in Greg Ryan, The Making of New Zealand Cricket 1832-1914, p. 226, also referenced in Owen Mann, 'The Cultural Bond?', p. 2203.

4 J. P. Carr, 'The First Golden Age? A Social History of New Zealand Cricket 1914-39', p. 146.

${ }^{5}$ New Zealand Cricket Council, Management Committee Minutes, 10 May 1929, New Zealand Cricket, Canterbury
} 
Council accepts your team with pleasure, grateful you arranged Duleepsinjhi [sic] Woolley, accommodation secured, Orford leaving London September twenty-eight. ${ }^{6}$

When the MCC members were interviewed on radio station 2YA it was Gilligan, along with Woolley and Duleepsinhji, who did the most talking. ${ }^{7}$ Woolley was one of the most famous names in the world of cricket in the first three decades of the twentieth century. His career spanned 32 years and he accrued nearly 60,000 firstclass runs and played 64 Test matches for England. ${ }^{8}$ His star status in New Zealand was undeniable and his stylish batting and fame meant he was an exceedingly 'bankable' figure for the NZCC. The New Zealand Free Lance gushed shortly before his arrival that:

Frank Edward Woolley is admittedly the greatest left-handed batsman England has produced and also one of the best batsmen of all time. The dream of many a New Zealand enthusiast that of seeing the great left-hander in action is to be realised this Summer. ${ }^{9}$

However much Frank Woolley may have been a star in his own right, Kumar Shri Duleepsinhji was clearly the greatest talking point. He was an Indian-born prince, super-star batsman and, most enthralling for the New Zealand public, the nephew of Ranjitsinhji, the great Indian prince who played for England during the 'golden' years of English cricket before the First World War. ${ }^{10}$

Duleepsinhji, like his uncle, was a prolific and stylish batsman. Although his career was cut short by illness, he scored 15,485 runs at an average just under $50 .{ }^{11}$ Duleepsinhji was born in Kathiawar, India, but moved to England and was educated at Cheltenham College and Cambridge University. When he arrived in New Zealand the media was unequivocal in its praise and excitement at having this exotic Indian-

\footnotetext{
${ }^{6}$ Ibid., 17 June 1929.

${ }^{7}$ The Dominion, 13 Dec 1929, p. 19.

${ }^{8}$ Frank Woolley statistics sourced from 'England/Players/Frank Woolley', Cricinfo; available from http://www.espncricinfo.com/england/content/player/22518.html; accessed 12 June 2011.

${ }^{9}$ New Zealand Free Lance, 4 December 1929, p. 46.

${ }^{10}$, Simon Wilde, 'Ranjitsinhji Vibhaji, Maharaja Jam Sahib of Navanagar [Ranjitsinhji or Ranji] (1872-1933)' ODNB; available from http://www.oxforddnb.com/view/article/35190; first published 2004; online edition, Jan 2011; accessed 12 June. 2011.

${ }^{11}$ Duleepsinhji's statistics sourced from 'England/Players/Duleepsinhji', Cricinfo; available from http://www.espncricinfo.com/ci/content/player/11951.html; accessed 12 June 2011.
} 
born relative of the great Ranji touring the country. The New Zealand Free Lance commented after Duleepsinhji had been in the New Zealand for a few weeks that:

We never had the pleasure of seeing Ranjitsinhji in action in New Zealand, but the few glimpses we have had of his nephew have been entrancing. He stirs the blood of cricket enthusiasts when he is making a score, as much by the rapidity of his batting as by the excellence of his strokes. A Sussex player like his uncle, he plays "tawny cricket that has lived much in the sun." ${ }^{12}$

The reporter's incorporation of Cardus' 'tawny cricket' phrase points to an acceptance of a casual racist tone that, Hoberman would suggest, is an example of the creation and perpetuation of notions of essential difference as opposed to the similarities of sportsmen. ${ }^{13}$ It also implies that their technique and approach was influenced by their ethnicity though qualified in the sentence by the fact that they played for a famous and successful English county. There is clearly an aesthetic value placed upon these Indian princes that, in association with their skin colour, further magnified the exotic. Ranjitsinhji was credited with developing a new stroke - the leg-glance - which, when played well, opened up an area of the field rarely populated with fieldsmen, but required skill and precision to execute. ${ }^{14}$ This aesthetic also led to the stereotyping of Indian cricketers as 'wristy', and therefore again classifiable as 'other'. ${ }^{15}$ Indian batsmen are just one example of how the language of race was used in sport. Other examples are the description of Aboriginal and Maori footballers as 'naturally gifted' or the myth of African hardiness and supernormal vitality. ${ }^{16}$ Though often attributable to lazy journalism and racial clichés, such stereotyping nevertheless perpetuates an assumption of difference from occidental players and the classical forms of the sport. For Duleepsinhji, and his uncle, the qualified exoticism that was associated with their obvious skills at the game popularised them and trumped most racist attitudes.

\footnotetext{
${ }^{12}$ New Zealand Free Lance, 22 January 1930, p. 43.

${ }^{13}$ Neville Cardus original quote comes from his article 'Ranji, Fry and Sussex' printed in Manchester Guardian, 30 May 1928, p. 4. Both the New Zealand writer and Cardus, who he is paraphrasing, appear to apply a doublemeaning to tawny, referring to the sunny nature of Sussex and tanned appearance of its players, but also as an allusion to skin colour being associated with a particular style of cricket.

${ }^{14}$ Many articles on Ranji's technique. Good brief article see Rahu Bhattacharya 'The Light of the East', Wisden Asia Cricket; available from http://www.cricinfo.com/magazine/content/story/447111.html; accessed 29 October 2010.

${ }^{15}$ On the 'otherness of Ranji', Jack Williams, Cricket and Race, p. 26.

${ }^{16}$ John Hoberman, Darwin's Athletes, p. 181.
} 
Ranjitsinhji's selection for England caused arguments to rage across the country in the 1890s. The reason behind his initial non-selection for 'Home' against the Australians was that he had not been born in England. This was clearly a raciallybased distinction as no such qualms applied to the white cricketers who, having been born in one country, played for another. ${ }^{17}$ Ranjitsinhji's popularity with fellow cricketers and the press, as well as the number of runs he had scored, forced the issue and he was selected for England against Australia in 1896. Neville Cardus, in his essay 'Ranji, Fry and Sussex' penned prior to the MCC 1929-30 tour proclaimed:

The light that shone on our cricket fields when 'Ranji' batted was a light out of his own land, a dusky inscrutable light. His was the cricket of black magic indeed. A sudden sinuous turn of the wrist and lo! the ball had vanished - where? The bowler knowing he had aimed on the middle stump saw as in vision, the form of 'Ranji' all fluttering curves. The bat made its beautiful pass, a wizard's wand. From the very middle stump the ball was spirited away to the leg-side boundary. ${ }^{18}$

What was it that made the three players - Ranjitsinhji, Duleepsinhji and Iftikhar Ali Khan, the Nawab of Pataudi (who also played for England in the 1930s) - so acceptable to the English and New Zealand publics beyond the excited or floral descriptions of their play? Jack Williams, in Cricket and Race, suggests that Ranji was seen as proof of the capacity for non-whites to assimilate to English values and British imperialism. Furthermore, by displaying English values, which are supposedly inherent in cricket, Ranji was proof of the superiority of English people and culture. ${ }^{19}$ Another possible factor contributing to the acceptance of these Indian cricketers was the value English culture placed on financial wealth, titles and status. All three men were from princely lineage and were independently wealthy and therefore, possibly, buffered from the racial attitudes held for poorer people of colour. Even so, the fact they were not white would always have been a point of difference. Patrick McDevitt, when referring to the Nawab of Pataudi, who played for the MCC on the Bodyline tour to Australia in 1932-33, considers that:

\footnotetext{
${ }^{17}$ Jack Williams, Cricket and Race, pp. 23-26. An example would be Charles Bannerman, who was born in Woolich, Kent, but played 3 test matches for Australia against England between 1877-79.

${ }^{18}$ Neville Cardus quoted in New Zealand Free Lance, 22 Jan 1930, p. 43, original article 'Ranji, Fry and Sussex, The Manchester Guardian, 30 May 1928, p. 4.

${ }^{19}$ Jack Williams, Cricket and Race, pp. 31-32.
} 
he occupied a unique position on the English side; elevated because of his wealth and amateur status, but somewhat subordinate because he was Indian. ${ }^{20}$

To be an Indian in New Zealand, and neither of royal lineage nor a member of the MCC, was certainly not an easy existence if the tone of the press at the time is an accurate reflection. The economic pressures facing New Zealand in the interwar years, particularly in the early 1930s, and the strict immigration laws, born of fear of foreign invasion meant minorities were seen as a problem in society. ${ }^{21}$ In 1932, a petition was presented to Parliament by J. N. Massey (Government, Franklin) on behalf of C. R. Lloyd and 1456 signatories. The petition stated that the there should be immediate repatriation of the some 6000 Chinese and Indians working in the Dominion mainly as market gardeners and hawkers and that their presence and long hours of work were depriving 'Europeans' of work opportunities. ${ }^{22}$ Apart from depriving 'Europeans' of such opportunities, the petition also suggested that most of these foreigners were:

living in insanitary and immoral conditions, gravely endangering the future of our present fine Maori race... Both Chinese and Indians come to New Zealand to make money, and return with it to their native land, thus continuously weakening the finances of New Zealand. It is estimated that they send $£ 100$ each annually out of the country, which means that $£ 600,000$ a year is completely lost to New Zealand instead of remaining here in circulation as would be the case if they were replaced by our own people... The Asiatics of New Zealand are undesirables, being invariably of a low caste and class in their own county. ${ }^{23}$

The two key points from this petition were that Indians were an economic threat and from an undesirable background and therefore the antithesis of what Duleepsinhji was to New Zealanders. The petition was clearly a result of the current economic disaster but the attitudes expressed were more endemic in society. During Duleepsinhji's visit to New Zealand with the MCC, a population census had been taken. Reporting the results, the Evening Post noted: 'New Zealand prides itself upon

\footnotetext{
${ }^{20}$ Patrick F. McDevitt, May the Best Man Win - Sports, Masculinity and Nationalism in Great Britain and the Empire 1880-1935, p. 92.

${ }^{21}$ For more detail on attitudes towards Indians at the time see Tony Ballantyne, 'India in New Zealand: The Fault Lines of Colonial Culture', in Sekhar Bandyopadhyay (ed.), India in New Zealand, Local Identities, Global Relations, Dunedin, 2010, pp. 30-44.

${ }^{22}$ Evening Post, 24 September 1932, p. 14.

${ }^{23}$ Ibid.
} 
being a "white” man's country, [with] laws being framed to prevent any undue influx of "coloured” races." 24

Duleepsinhji's royal title, wealth and undoubted ability with the bat - which saw him well-regarded in New Zealand - did not prevent him from being at the centre of a race- based selection drama. In 1929, the same year he toured New Zealand, Duleepsinhji was selected for and made his test match debut in the first test England played against South Africa at Edgbaston, Birmingham. He had an indifferent game with scores of 12 and 1 in a drawn test. He was harshly dropped for the rest of the series but reinstated for the MCC tour of New Zealand just a matter of months later. It was alleged that the South African team management objected to his selection against South Africa because he was Indian-born. ${ }^{25}$ He was removed from the team, despite the precedent that had been set by his uncle and that he had qualified for England under ICC rules, having played for Cheltenham College, Cambridge University and Sussex. ${ }^{26}$ Although playing against New Zealand in 1929 and 1931, and a personally successful series against Australia in 1930, he was not included for the series played in South Africa in 1930-31 (South Africa won). If Duleepsinhji had played and succeeded there was a concern that such a result would lead to greater unrest and resentment in the Republic's non-white communities. ${ }^{27}$

There is no reference to the South African series when Duleepsinhji toured New Zealand, nor was there any question concerning his place in the team on account of his colour. Instead what appears is curiosity and excitement as he travelled around the country. In the newspaper accounts, Duleepsinhji is depicted as shy, though with a cheeky humour and displaying a fairly competitive streak on the field. His team mates refer to him as 'Smith', a name he had been given at Cambridge, which had clearly stuck. ${ }^{28}$ Such was the interest and fascination in him, that at one stage the readers of the New Zealand Free Lance were informed that he thinks toheroa soup is 'one of the best he has ever tasted'. He was then asked whether he thought the New

\footnotetext{
${ }^{24}$ Evening Post, 22 February 1929, p. 11.

${ }^{25}$ Bruce Murray \& Christopher Merrett, Caught Behind - Race \& Politics in Springbok Cricket, pp. 36-38.

${ }^{26}$ Ibid, p. 37.

${ }^{27}$ Jack Williams, Cricket \& Race, pp. 33-34 \& Bruce Murray \& Christopher Merrett, Caught Behind - Race \& Politics in Springbok Cricket, p. 37. Further reading on Duleepsinhji non selection see Alan Ross, Ranji, Prince of Cricketers, Rex Roberts \& Simon Wilde, Duleepsinhji, Learie Constantine, Cricket in the Sun, and Mihir Boses, History of Indian Cricket

${ }^{28}$ Maurice Turnbull \& Maurice Allom, The Book of the Two Maurices, London, 1930, p. 88-89.
} 
Zealand girls were smart? Duleepsinhji, probably embarrassed, replied, 'Oh yes. I should just say so! I think they are smart. They are very pretty and smart. But you ask the others. They are much better to ask than I am.'29

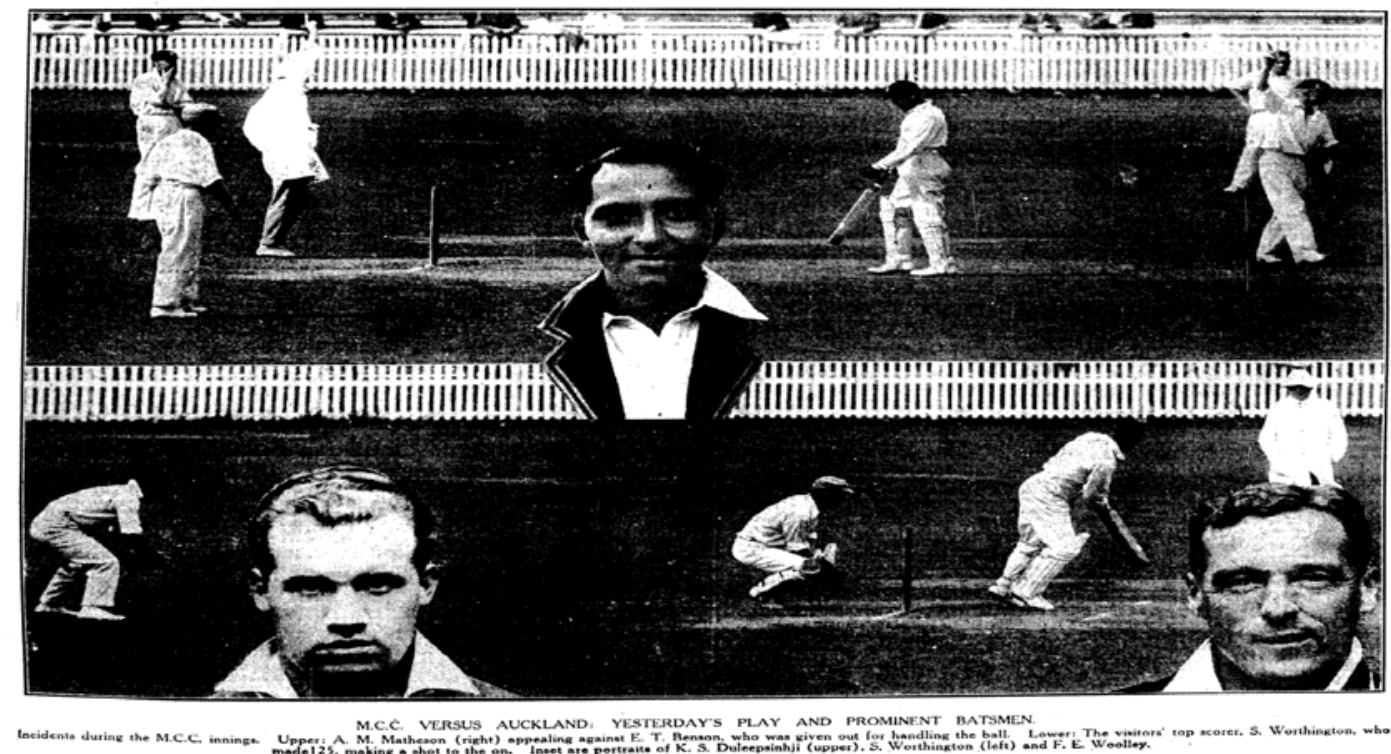

'MCC versus Auckland', New Zealand Herald, 11 February 1930, p 8. Image reproduced courtesy of the Alexander Turnbull Library

Duleepsinhji was certainly never far removed from the shadow of his uncle, either through constant comparison or the interventions of Ranjitsinhji himself. ${ }^{30}$ In 1932, Ranjitsinhji discouraged the request for his nephew to trial for the Indian team that was to tour England and he instead played for Sussex against the Indian team, hoping to make the England team for the Ashes tour of 1932-33. ${ }^{31}$ As Ramachandra Guha points out in A Corner of a Foreign Field, while India was still ruled by Britain, it was nevertheless possible for the anomaly of playing for both India and England to occur, though neither Duleepsinhji nor the Nawab of Pataudi were chosen for England in the Test against India in 1932. ${ }^{32}$

Unsurprisingly, Duleepsinhji topped the averages for the MCC tour of Australasia in 1929-30 and was a major contributor to the team winning the Test series against

\footnotetext{
${ }^{29}$ New Zealand Free Lance, 29 January 1930, p. 9.

${ }^{30}$ Examples of Duleepsinhji being compared to Ranjitsinhji, The Dominion 26 1929, p. 8; New Zealand Free Lance, January 22 1930, p. 43; New Zealand Herald, 12 February 1930, p. 12.

${ }^{31}$ Ramachandra Guha, A Corner of a Foreign Field, pp. 193-194; Jack Williams, Cricket and Race, p. 25.

32 Ibid. p. 194
} 
New Zealand 1-0. ${ }^{33}$ The tourists travelled through New Zealand without losing a game, although they were nearly defeated by Wellington in the first match of the tour. The four Test matches were evenly fought, except for the first test in which New Zealand's batting collapsed twice for scores of 112 and 131 in an eight wicket defeat. ${ }^{34}$ Prior to this match, the New Zealand press had been bullish about New Zealand's chances but afterwards were scathing about Tom Lowry's captaincy and the home side's weak effort. One colourful report of the disastrous start to the series summed up the mood of the public:

"The stage is set," said an enthusiastic official this morning, "for one of the greatest test matches in the history of New Zealand cricket." Alas! The curtain had not been rung up when the scenery collapsed and the players floundered amongst the ruins in pathetic helplessness. The morning's play at Lancaster Park was, from a New Zealand point of view, tragic but it was a tragedy which quickly turned to comedy for the crowd, so futile were the efforts of the batsmen to stay at the wickets. ${ }^{35}$

Tom Lowry had been a first class cricketer since 1919 and was New Zealand's most astute and travelled player. He had captained Cambridge University and played first class cricket for Somerset. He was known for unorthodox fielding placements and aggressive captaincy. ${ }^{36}$ In this test though it was noted that the team appeared to lack the dash and energy in the field that was so evident in their opponents. To The Truth this was clearly something the captain was failing to address.

Tom Lowry would be well-advised to buck up. Cricket can be made a slow and dreary game from the spectators' point of view and it is for the captain of a side to see that play is made attractive for the man who pays. If "TC" will take this little hint he will add considerably to his popularity as a skipper. $^{37}$

The defeat stung New Zealand but the team's response was to run the MCC side close for the rest of the series. The second Test was drawn, with New Zealand in a

\footnotetext{
${ }^{33}$ He scored 890 runs at an average of 49.44 in first class games over the tour.

${ }^{34}$ D. Neely et. al. Men in White, pp. 100-101.

${ }^{35}$ Otago Daily Times, 11 January 1930, p. 14.

${ }^{36}$ See biography of Tom Lowry, Don Neely. 'Lowry, Thomas Coleman - Biography', DNZB, Te Ara; available from http://www.TeAra.govt.nz/en/biographies/4l17/1; updated 1 Sep 2010; accessed 6 May 2011.

${ }^{37}$ New Zealand Truth, 23 Jan 1930, p. 16. Called "TC" as his full name was Thomas Coleman Lowry.
} 
strong position, and the third Test was ruined by rain. ${ }^{38}$ New Zealand cricket was believed to have lost approximately $£ 1000$ in potential takings, as the match was not insured against rain because the cost was considered too high. ${ }^{39}$

After some debate, Gilligan agreed to play a fourth Test in order to help the NZCC out of the financial problem the shortened third Test had caused. This match was also drawn, which showed New Zealand's improvement but increased the frustration felt by the public who were keen for positive outcomes in the matches. The Tests were set as three-day matches, which, if the wicket was true, and the weather not a factor, was not generally enough time to post a competitive score as well as claim the 20 opposition wickets required for victory. The length of matches was set before the tour by the MCC and reflected New Zealand's lowly position in international cricket. The MCC had a strong team playing in the West Indies at the same time who played three five-day Tests and one test with no time restriction which lasted nine days. ${ }^{40}$ Furthermore, the wickets themselves were conducive to batting arguably to extend the length of matches. The New Zealand Truth, along with other newspapers, protested about this situation:

Three drawn Tests out of four provide a vivid testimony to the sheer futility of the absurd time limit enforced by the bigwigs of the MCC in England. Even Plunket Shield matches go for four days... The end of the fourth cricket Test at Auckland was about as satisfactory as the circumstances under which it was arranged. On a "starch front" Eden Park wicket, it took two sides an hour short of three days to complete a single innings each. The ridiculous three-days limit and the Englishmen's safety first tactics were at the bottom of it. Faced with the mammoth score of 540, and no chance of winning, the Enzedders simply dug in for a day and a half. A team of professional grave-diggers could not have beaten it. ${ }^{41}$

When the tour ended there was little criticism of the MCC team, except for their occasionally conservative batting. The disappointment in the matches was directed

\footnotetext{
${ }^{38}$ D. Neely et. al. Men in White, pp. 101-103. For series analysis see also Gerry Cotter, England versus New Zealand, pp. 67-75.

${ }^{39}$ The Dominion, 17 February 1930, p. 16.

${ }^{40}$ New Zealand Free Lance, 5 February 1930, p. 40 and www.cricketarchive.com (accessed 3/07/2010). See also J. P. Carr, 'The First Golden Age? A Social History of New Zealand Cricket 1914-39', p 151; also Jack Williams, Cricket \& Race, p. 33.

${ }^{41}$ New Zealand Truth, 27 February 1930, p. 14.
} 
primarily at the New Zealand side, which lacked bowling firepower and the ability to take catches. The MCC side had in fact surprised people with their affability and generally bright batting. When the MCC played Otago it was reported that:

It is no secret in Dunedin that members of the previous team hailing from the Old Country had not gone out of their way to ingratiate themselves with the people of a city which has long had a good name for its hospitality to visitors. The fact that A. H. H. Gilligan and his men have proved themselves to be "good mixers" and jolly good fellows altogether is one to be regarded with satisfaction. ${ }^{42}$

One of the umpires in the series, Thomas Cobcroft, commented after the MCC left that:

I am satisfied that none of the amateurs of this team would have stood for the old senseless practice of being billeted at a different hotel to that of the professionals. Several of the players both amateur and professional assured me that there had not been a cross word spoken by any member of the team since they left England and were perfectly sure the same state of things would exist to the return home. ${ }^{43}$

These articles give a sense that this team was very much a break with the traditions of past teams, and indeed this tour was a goodwill event with an emphasis on 'fair play' and friendly relations. The attitude was clearly greeted well in New Zealand. Dan Reese, who played against the Lord Hawke XI in 1902-03 and the MCC in 1906-07, was President of the NZCC during this tour. Speaking at a dinner for the players, he said 'he was glad that a percentage of professional players was included in the present team, for there had in that way been built up a more representative team of real English cricketers. ${ }^{44}$ This tour hints at a slight change, though not seismic shift, in the way professionals were treated after the Great War. It is possible that the MCC were becoming aware of the uncomfortable feelings within the Empire regarding evident class division within sport. ${ }^{45}$ What is interesting and important is the difference in class structures within cricket between England and New Zealand at the time and how this impacted on results. New Zealand had a very limited pool

\footnotetext{
${ }^{42}$ New Zealand Free Lance, 8 January 1930, p. 47.

${ }^{43}$ The Dominion, 5 March 1930, p. 8.

${ }^{44}$ New Zealand Herald, 11 December 1929, p. 14.

${ }^{45}$ For discussion on professional amateur debate in England in the interwar years see Jack Williams 'The Really Good Professional Captain Has Never Been Seen!' Perceptions of the Amateur/Professional Divide in County Cricket, 1900-1939', Sport in History, Vol. 26, No. 3, December 2006, pp. 429-449.
} 
of professional cricketers because the structure of the sport could not sustain nor justify the cost. English cricket by contrast could sustain a large number of professionals, who were often the county sides' bowling stock. While New Zealand's few professionals were often paid to both play and coach and were not necessarily working class, the English professionals were effectively paid labourers, largely working class, whose employment was reliant on their success on the field. The English team system clearly placed amateurs above professionals and even in the 1930s the relationship was at times akin to master and servant. ${ }^{46}$ While New Zealand cricket's higher echelons certainly understood the hierarchical principles at play in English cricket, such practice was less palatable and clearly unfeasible within New Zealand's social and sporting fabric. The dynamics of the two countries were quite different and New Zealand attitudes towards the treatment of English professionals possibly says more about the New Zealand attitude towards the treatment of the working class than they do about the playing merits or otherwise of amateurs and professionals.

\footnotetext{
${ }^{46}$ For an example of relationship between professionals and amateurs in interwar years see Duncan Hamilton, Harold Larwood, London, 2009, pp. 25-113.
} 


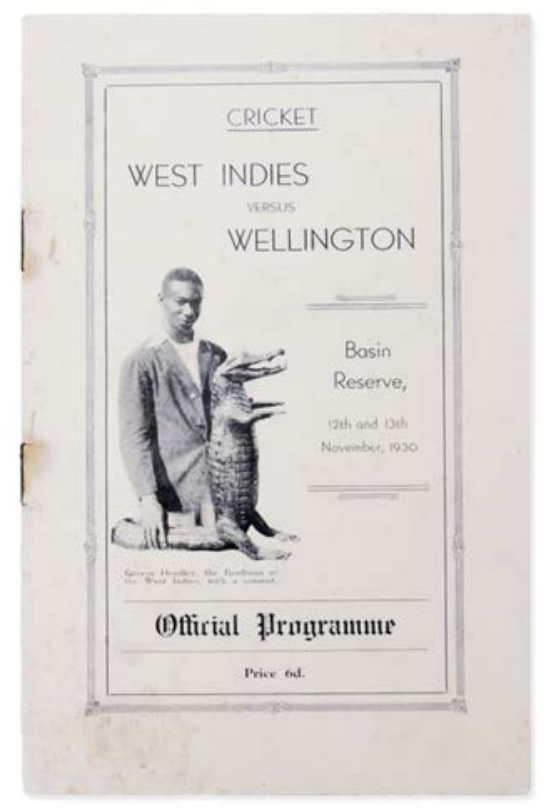

West Indies v Wellington, 1930, Official Programme,

Printed Ephemera Collection, Courtesy of New Zealand Cricket Museum

\section{The West Indies - 1930-31}

The West Indies made their inaugural tour of Australia in the 1930-31 season. Their journey included a brief stop in Wellington which, when discovered by the Wellington Cricket Association (WCA), led to an optimistic request for the West Indies to play Wellington in a two-day match. The tourists agreed and the match started on the same day the boat arrived in Wellington harbour. The result was a draw with some influence from the weather. But this short trip still provided Wellingtonians and the New Zealand press with a glimpse of the West Indies side who were clearly keen to stretch their legs after the long journey.

The West Indies team was one of the first predominantly non-white teams to visit New Zealand. ${ }^{47}$ The West Indian side contained seven white players and eleven nonwhite and was captained by George Copeland Grant, one of the white players. ${ }^{48}$ The

\footnotetext{
${ }^{47}$ The first major tours to New Zealand in the 20th Century by non-white sports team were a Chinese University selection in 1924 and the Indian hockey team that visited New Zealand in 1926. There had been a tour by a Fijian cricket team in 1895-96, which included a number of indigenous players.

${ }^{48}$ Andrew Honey, 'Sport, Immigration, Restriction and Race - The Operation of the White Australia Policy', p. 42.
} 
entire team, and in particular the two non-white stars, George Headley and Learie Constantine, were a novelty. They were welcomed to New Zealand and indeed celebrated because they were cricketers of ability and well-known sportsmen. Like Duleepsinhji before them, they were admired as sportsmen, which disarmed any concerns aroused by their colour. The tour, though brief, showed the multi-racial nature of Empire but also the hierarchical realities of sports in the period.

The West Indies had been a Test 'nation' since 1928 and, like New Zealand, were very much second-class citizens of the Test cricket world. When one MCC team was in New Zealand in 1929-30, the MCC also sent a team at the same time to the West Indies, confirming the lesser status of both Test nations. ${ }^{49}$ The awarding of Test status was, though, a result of the overall quality of West Indian cricket and the undeniable class of emerging black cricketers such as Learie Constantine and George Headley. Unfortunately, after gaining Test status, the West Indies were heavily defeated by England in a 3-0 test series. Undaunted, they won their first Test match against England in $1930 .^{50}$ On their inaugural visit to Australasia, which included the match against Wellington, they defeated Australia in the fifth and final Test at Sydney, although losing the series 4-1.

The West Indies itself is not a single political entity but a widespread collection of former British colonies set in the Caribbean Ocean and extending from Jamaica to Guyana. Cricket in the region had evolved from a game played solely by the plantermerchant elite to one more racially-pluralistic though stratified in the first quarter of the twentieth century. ${ }^{51}$ The advancement of this Test 'nation' was influenced by the work of cricket crusaders like Pelham 'Plum' Warner who encouraged non-white selection at the higher levels, and the successful fusion of the region's diverse backgrounds and ethnicities towards a common sporting goal. For C. L. R. James,

\footnotetext{
49 Jack Williams, Cricket \& Race, p. 33.

${ }^{50}$ West Indies defeated the MCC by 289 runs at Bourda Georgetown. Match details see 'Marylebone Cricket Club in West Indies 1929/30 (3rd Test)', Cricket Archive; available from http://cricketarchive.com/Archive/Scorecards/13/13377.html; accessed 29 October 2010.

${ }^{51}$ Hilary Beckles, The Development of West Indies Cricket, pp. 9-12; Brian Stoddart 'West Indies' in The Imperial Game, p. 84.
} 
the great West Indian journalist and social theorist, 'the clash of race, caste and class didn't retard but stimulated West Indian cricket. ${ }^{52}$

The inclusion of non-white players within West Indies selections was largely a pragmatic decision by administrators such as Warner. He had promoted the advancement of black cricketers not because they were black but because their development as cricketers would lead to a stronger West Indian side. Beckles argues that 'Plum's social understanding was that white and black cricketers in the West Indies and those in England, for whom he was a conduit, were held together by ideological bonds, symbolized in the social and cultural practice of cricket. ${ }^{53}$ Such an attitude was not always welcome. Non-white players faced racist imagery from the British press when they first visited at the beginning of the twentieth century and were still treated poorly in the interwar years. ${ }^{54}$ McDevitt notes that when the West Indies side toured England in 1933, the black players were treated for the most part as children and that even the best players were considered 'something akin to idiot savants, whose great skills came not from hard work and intelligence but from some indefinable and innate trait. ${ }^{55}$

When the team arrived in Sydney after leaving Wellington in 1931 the white players were initially placed in a separate hotel from the rest of the team. This was quickly changed on request of the tourists, and the initial segregation appears to be a result of confusion about the make-up of the team and how the visitors should be processed in relation to the White Australia Policy. ${ }^{56}$ The tour went ahead apparently with several cultural misunderstandings because the Australian officials lacked the necessary knowledge of West Indian culture and society. ${ }^{57}$ Andrew Honey suggests that the West Indies, like other non-white sporting tourists, were exceptions to the policy of racial exclusion and often exceptions to the rationale for the policy itself.

\footnotetext{
${ }^{52}$ C. L. R. James, Beyond a Boundary, p. 88.

${ }^{53}$ Hilary Beckles, The Development of West Indies Cricket, p 39; For Warner, cricket provided an adhesive force to the Empire and is why he was such a proactive cricketing tourist and proponent of mixed West Indian sides. Derek Birley describes Warner as 'a travelling salesman of cricket', for not only did he represent England at Test level in overseas tours, but over his long cricketing career, he was a constant MCC tourist playing in Imperial tours to New Zealand, Argentina and South Africa. See Derek Birley, A Social History of English Cricket, p. 169.

${ }^{54}$ Hilary Beckles, The Development of West Indies. pp. 39-41.

${ }^{55}$ Patrick F. McDevitt, May the Best Man Win, p 117.

${ }^{56}$ Andrew Honey, Sports, 'Immigration Restriction and Race - The Operation of the White Australia Policy', pp. 41-44. Honey has sourced West Indies Board of Control to Australian Board of Control (cable), quoted in Chris Harte, A History of Australian Cricket, London, 1993, p. 328-329.

${ }^{57}$ Ibid. p. 42.
} 
They were affable and not an economic threat and therefore acceptable visitors for a short term visit that did not threaten Australian white homogeneity. ${ }^{58}$

The West Indies team was captained and administered by white cricketers, thus confirming the racial hierarchy was still in place. The social order may have been retained but this was at the cost of the integrity of the captaincy and harmony of the team. When George Copeland Grant brought his side to New Zealand he was only 23 years old and had little experience in the role. In The West Indies in Australia 1930-31, Brian Bassano and Rick Smith noted that 'although the West Indies Test history amounted to only seven games, Grant had played in none of them, and it could be argued that he had little real knowledge of West Indies Cricket and the players he was leading, as he had never taken part in top level cricket there. ${ }^{59}$ Both Grant and the team's assistant manager, Joe Scheult, were lay missionaries and encouraged the team to attend church every morning. ${ }^{60}$ Perhaps it was Grant's religious convictions and discipline that were considered more important to the team dynamic than his ability or experience at cricket. His selection along with other white senior players confirmed the continued divide and disenfranchisement apparent within West Indian cricket in the interwar years. Beckles concluded that the West Indian team of this period:

remained riddled with racism and class arrogance, and players from different social backgrounds did not feel each other's needs because no natural channels of communication existed between them. In general, whites did not socialize with non-whites off the field, and blacks were divided among themselves by the attitudes derived from their reading of how privilege operated within the colonial society. ${ }^{61}$

When the West Indies arrived in Wellington there appears no clear evidence of the press representatives picking up on this division; instead there was curiosity aroused by these exotic cricketers and people's eyes remained transfixed on Learie Constantine and the other non-white players, whose skills and abilities were noted. Furthermore, there is no clear evidence Constantine's colour adversely affected him

\footnotetext{
${ }^{58}$ Ibid. p. 46.

${ }^{59}$ Brian Bassano \& Rick Smith, The West Indies in Australia 1930-31, Prospect Vale, 1990, p. 1.

${ }^{60}$ Andrew Honey, Sports, 'Immigration Restriction and Race - The Operation of the White Australia Policy', p. 42

${ }^{61}$ Hilary Beckles, The Development of West Indies Cricket, p. 51.
} 
being considered one of the best, if not the best cricketer in the world. The Otago Witness provides example:

L. N. Constantine, a member of the West Indies cricket team is "Learey" [sic] to the Trinidad and other West Indian crowds, as this is his first Christian name. Just 28 years of age and right at his top in his cricket and athletic life, in his own country it is questioned if there is a better all-round cricketer in the world just now than Constantine, his fielding being ranked "on its own". ${ }^{62}$

The match itself, like so many games played by touring sides in New Zealand during the 1930s, was affected by rain. Wellington batted first and struggled to 195 all out. Unsurprisingly, Learie Constantine was the star, taking 6-24 including the prized wicket of Stewie Dempster. In the time left the West Indies reached 128 for 4 but the chance of seeing Constantine bat was lost due to the arrival of rain. Apart from Constantine's outstanding bowling display, it was the fielding skill of the West Indians as a whole that caught the eye of the local press. The New Zealand Free Lance enthused:

I place the West Indies cricket team, which spent an all too short few hours on the Basin Reserve, Wellington, last Wednesday and Thursday afternoons, on a very high plane in this respect. There is no denying the fact that these players are the finest fielding side that have ever visited New Zealand. Every one of them was a rare trier and every run scored by the Wellington batsmen was honestly earned... With L. M. Constantine as the outstanding figure, these darkskinned players gave a real object-lesson of what fielding really meant. ${ }^{63}$

The glow which seemed to surround Constantine was a constant in his remarkable life. Constantine's cricketing career started with the club side Shannon in the racially-stratified Trinidadian competition, described by C. L. R. James as the 'club of the black lower-middle class: the teachers, the law clerk, the worker in the printing office and here and there a clerk in a department store. ${ }^{64}$ His ascent was perhaps partially predictable since he was born into a family of cricketing royalty. His father scored the first century for the West Indies against a team led by W. G.

\footnotetext{
62 Otago Witness, 18 November 1930, p. 48.

${ }^{63}$ New Zealand Free Lance, 19 November 1930, p. 49.

${ }^{64}$ C. L. R. James, Beyond a Boundary, p. 67 Constantine himself was a law clerk.
} 
Grace at Lords. ${ }^{65}$ Constantine made his test debut in 1928 and was a professional in the Lancashire Leagues, mainly with the Nelson club where his numerous bowling, batting and fielding exploits are legendary. League matches were limited to one day and during one match in 1937 he scored 192 not out against East Lancashire of which the last 152 runs came in just 57 minutes. ${ }^{66}$ When asked by a New Zealand Free Lance reporter in Wellington about the English leagues, his reply confirms his passion for the game despite the weather that often seems to follow it:

I enjoy playing under the Lancashire League in England: the matches are taken seriously, both by the players and the public. The weather may be wet and cold, but the players have to hang on in the hopes of getting some play. The matches are all played on Saturday afternoons and are limited to the one afternoon. I have taken part in matches in which only twenty minutes of play possible because of rain, but we carried on all the same. ${ }^{67}$

It was Constantine's enthusiasm for cricket and his skill which made him so admired by the Nelson public, an admiration which followed him wherever he played. Despite the rarity of black cricketers in England, and the racism which was all too evident, Constantine was rarely abused. ${ }^{68}$ Perhaps, like Duleepsinhji before him, Constantine's success at cricket, accompanied by his abundant good nature, were considered a consequence of the successful transmission of English character traits through this most English of games, cricket. Perhaps it confirmed in some people's minds the capacity of the English to rule others well. Jack Williams noted that there were few instances of colour being mentioned in English newspapers, and although Constantine was referred to as 'the dusky terror' in an English paper, and the New Zealand Free Lance reporter who interviewed him after the game in Wellington referred to him as the 'dusky champion', this was hardly arrant racism. ${ }^{69}$ Angus Calder, in an article on Constantine, argues that 'the extrovert, exciting qualities of

\footnotetext{
65 Ibid. pp. 134-135.

${ }^{66}$ Angus Calder, 'A Man for All Cultures: The Careers of Learie Constantine', Culture, Sport, Society, Vol. 6, No. 1, Spring 2003, p. 33.

${ }^{67}$ New Zealand Free Lance, 19 November 1930, p. 43.

${ }^{68}$ Jack Williams does those raise several moments of racism towards Constantine. He was rejected a position in the Lancashire County team because of the upset in the team over a black man replacing a white man. Also famously in 1943 Constantine and his family were told they could not stay more than one night at the Imperial Hotel in Russell Square in London because his presence may offended Americans who were staying. Margaret O'Sullivan, the manageress, was quoted as saying ' "We won't have niggers in this hotel." Jack Williams, Cricket and Race, pp. 39-40; also Martin Williamson, 'We Won't Have Niggers in this Hotel', Cricinfo Magazine; available from http://www.espncricinfo.com/magazine/content/story/333401.html; accessed 26 June 2011

${ }^{69}$ Constantine referred as the dusky champion in New Zealand Free Lance, 19 November 1930, p. 43.
} 
his play both disarmed and appealed to the racism of the period. ${ }^{70}$ In a sense he was not a threatening presence because his delight and enthusiasm for the game arguably came across to white people as the stereotyped childlike innocence of the benign black. The British journalist Denzil Batchelor in Game of A Life Time, published in 1953, exemplifies the casual racism that was inherent in praise for the star allrounder:

Learie Constantine is the only Negro I know who makes it impossible for you to forget that he is a Negro and who makes you wish that you were fine enough to be a Negro too. $\mathrm{He}$ is a philosopher; but a negro philosopher. He wears through life, like a flamboyant tie, the natural merriment of a childlike race; but as an intelligent and sensitive man he bears also the marks with which experience has branded him. $^{71}$

Jack Williams in Cricket and Race states that 'no prominent figure from cricket or politics argued between the wars that England should not be playing cricket against non-whites and no first class cricketer appears to have made a public statement that he did not wish to play against the Indians or West Indians because of their colour. ${ }^{72}$ The evidence is that the same would appear to be the case in New Zealand, though clearly the opportunities to play non-white cricketers were far fewer in New Zealand. Interestingly though, the Dominion noted during the West Indies visit that the MCC had suggested 'a few years back' that New Zealand should invite the West Indies team to tour, but that the proposal was 'scornfully declined. ${ }^{73}$ Rather than reflective of any latent racism, this response was potentially because the financial consequences of such a tour, as well as the preponderance of MCC tours, were uppermost in the minds of New Zealand cricket's higher echelon. The NZCC was, before World War Two, heavily influenced by officials from Canterbury, notably Frederick Wilding, ${ }^{74}$ Dan Reese, ${ }^{75}$ Sir Arthur Donnelly and Sir Arthur Sims. ${ }^{76}$ This region is considered the most English-orientated part of New Zealand, and, when

\footnotetext{
${ }^{70}$ Angus Calder, 'A Man for All Cultures: The Careers of Learie Constantine', p. 24.

${ }^{71}$ Denzil Batchelor, Game of a Lifetime, London, 1953, p. 94.

72 Jack Williams, Cricket and Race, pp. 34-35.

${ }^{73}$ The Dominion, 5 November 1930, p. 15.

${ }^{74}$ Fiona Hall, 'Wilding, Frederick - Biography', DNZB, Te Ara; available from http://www.teara.govt.nz/en/biographies/2w19/1; updated 1 Sep 2010; accessed 6 May 2011.

${ }^{75}$ Fiona Hall, 'Reese, Daniel - Biography', DNZB, Te Ara; available from http://www.TeAra.govt.nz/en/biographies/3r9/1; updated 1 Sep 2010; accessed 6 May 2011.

${ }_{76}$ A. H. McLintock (ed.), 'Outstanding Players and Administrators', An Encyclopaedia of New Zealand, originally published in 1966. republished in Te Ara - the Encyclopedia of New Zealand; http://www.teara.govt.nz/en/1966/cricket-mens/6; updated 23 Apr 2009; accessed 6 May 2011.
} 
originally organised by the Canterbury Association, the aim was to create a hierarchical English society with the Anglican Church at its centre. ${ }^{77}$ Therefore, the 'Englishness' of Canterbury meant New Zealand cricket was more drawn to tours by the MCC. Even so, when the West Indies were in Australasia in 1930-31, the NZCC were keen for the team to return to New Zealand for more games after the Australian series. ${ }^{78}$ The Evening Post reported that there were hopes that the West Indies would come back for three weeks and therefore an extensive tour, but that this was not possible as some of the players were required back in England for League cricket, and the captain intended to visit India after the Australian tour. ${ }^{79}$ The West Indies team did briefly stop in Wellington in order to catch the ship Mataroa that would take them back to the Caribbean via the Panama Canal. During their very brief stay the WCA arranged for them to be driven round the city to see the sights. The West Indies' assistant manager, Mr Scheult, said before leaving, 'we are looking forward to knowing more of the people of New Zealand. Any tour however would be unlikely until after 1933'. ${ }^{80}$ Sadly for cricket enthusiasts, the West Indies did not visit New Zealand again until the 1951-52 season, which was also the next time the West Indies toured Australia. In the interim years, the West Indies would play England in five separate test series.

The West Indies visit in 1930 was too short to afford greater emphasis, but the interest in the team and the wish for their return constituted a clear desire for closer sporting ties with non-white cricketers by New Zealanders. The West Indies were welcomed on account of their ability and star appeal but also because their visit did not constitute an economic or social threat. To what degree the non-white players advanced the social standing of people of colour in the eyes of New Zealanders, or entrenched perceived racial stereotypes, is hard to ascertain. Andrew Honey argues that the West Indies' visit to Australia, as with others made by non-white sportsmen, 'probably strengthened, rather than weakened, the racial images that lay behind the White Australia Policy.' ${ }^{81}$ For Wellingtonians the short visit certainly was welcomed

\footnotetext{
${ }^{77}$ John Wilson, 'Canterbury region - Overview', Te Ara; available from http://www.TeAra.govt.nz/en/canterbury-region/1; updated 2 Mar 2009; accessed Jan-Feb 2011.

${ }_{78}^{78}$ New Zealand Cricket Council, Management Committee Meeting, 10 October 1930.

${ }^{79}$ The Evening Post, 14 November 1930, p. 11.

${ }^{80}$ The Evening Post, 10 March 1931, p. 11.

${ }^{81}$ Andrew Honey, Sports, 'Immigration Restriction and Race - The Operation of the White Australia Policy', p. 42.
} 
because of the curiosity of seeing this team. The visit despite its brevity gave a taste of the broader world of international cricket and the game's potential to be a cultural link between different people of Empire. The visit also gives further evidence of the capacity of cricket to raise non-white players to positions of relative on-field equality with their white team mates and opponents. 


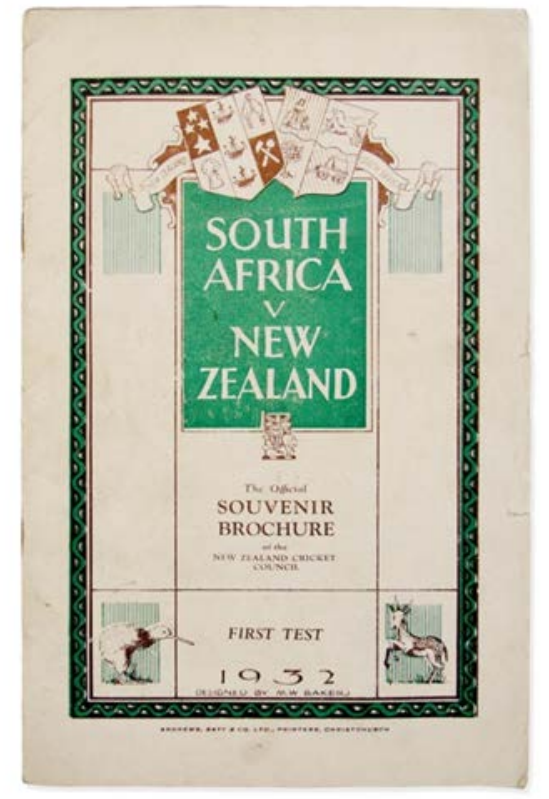

'South Africa v New Zealand 1932', Souvenir Brochure,

Printed Ephemera Collection, Courtesy of New Zealand Cricket Museum

\section{South Africa 1931-32}

One year after the West Indies visit to New Zealand, a South African Test team arrived following their inaugural tour of Australia. The South Africans' visit was the result of some intelligent opportunism by the NZCC and came as something of a surprise to the New Zealand cricketing public. Having concluded their tour of Australia, the South African team encountered 'inconvenient steamer sailings' for the return journey to their home country. Becoming aware of this, the eager NZCC immediately sent a telegram to the South African team, inviting them on a short tour to New Zealand. ${ }^{82}$ This was promptly accepted. Importantly, this tour would be the first visit by a South African cricket team to New Zealand. In contrast, a rugby team from South Africa had visited New Zealand in 1921 and a New Zealand selection had played in 1919 on return from the War. The All Blacks had toured in 1928. One advantage of the proposed games was that they would give the New Zealand team an opportunity to test itself against the third-ranked test nation. "Bragging rights"

\footnotetext{
${ }^{82}$ New Zealand Cricket Council, Management Committee Minutes, 5 November 1931.
} 
would also be in order for the victor. For the New Zealand public, the tour would give them a glimpse of a cricketing nation that was in many ways similar to their own, while in other ways, drastically different.

The South African team that had been selected for the tour was entirely white and predominantly of English ancestry, though it did include a player called Xenophon Belaskas of Greek parentage. He was referred to as the 'young Greek' by an excited New Zealand press. ${ }^{83}$ Balaskas aside, the make-up of the team reflected the nature of South African cricket in the period, where sporting segregation had snuffed out opportunities for all non-white players. Upon their arrival in New Zealand, the visitors were treated with great respect and admiration. South Africa's racially and ethnically charged cricketing history was certainly not an issue for discussion in the press.

Cricket had been played in South Africa since the arrival of the English military. The game was diffused through the country by the English during the first half of the nineteenth century. Following the discovery of mineral deposits in the period 18751885, many thousands of Europeans immigrated to South Africa. Their arrival coincided with the institutionalisation of sports in South Africa. ${ }^{84}$ When the first South African Test team was announced it included two players from the Dutch community, Arthur Ochse and Nicolaas Hendrik Theunissen. ${ }^{85}$ When the AngloSouth African war began, Dutch interest in the English game declined. It 'became associated with English cultural values and was thus despised by the Boers, who were fighting to maintain their own identity and independence. ${ }^{\prime 86}$ The game would not die out amongst the Afrikaner community but would only begin to reclaim prominence after World War Two. ${ }^{87}$ Even so, the team which came to New Zealand in 1932 included Ken Viljoen and Denijs Morkel, who were of Dutch ancestry.

\footnotetext{
${ }^{83}$ New Zealand Free Lance, 9 March 1932, p. 44 \& Otago Daily Times, 8 March 1932, p. 8.

${ }^{84}$ Dean Allen, 'South African Cricket, Imperial Cricketers and Imperial Expansion, 1850-1910', The International Journal of the History of Sport, Vol. 25, No 4, March 2008, pp. 451-452, Allen references the work of A. Odendaal, 'South Africa's Black Victorians: Sport and Society in South Africa in the Nineteenth Century', in J. A. Mangan (ed.), Pleasure, Profit, Proselytism, British Culture at Home and Abroad 1700-1914, London, 1988, pp. 193-214

${ }^{85}$ Dean Allen, p. 460.

${ }^{86}$ Ibid, p. 461.

${ }^{87}$ Bruce Murray and Christopher Merritt, Caught Behind - Race \& Politics in Springbok Cricket, pp. 30-31.
} 
The story of non-white cricket in South Africa mirrors the tragedy of South African race relations stretching back to the time of the first European contact and British settlement. Black South Africans are recorded as having played cricket from as early as the English arrival, and certainly since 1869 in Port Elizabeth. ${ }^{88}$ Black cricket teams in the nineteenth century took up English names such as 'Kimberly', which Merrett and Nauright, in The Imperial Game, argue was not mimicry but clearly an attempt to show their respectability and middle-class credentials. ${ }^{89}$ Unfortunately for such aspirations, cricket in South Africa from the 1880s was clearly a tool of British imperialist ideology. Racial exclusion of non-whites in cricket was encouraged in order to affirm white solidarity in response to the larger and seemingly threatening indigenous population. ${ }^{90}$ Black South African involvement in first-class cricket in the nineteenth (and most of the twentieth century) was never seriously considered, since black disenfranchisement from sport and other aspects of society was considered an important means of maintaining white cohesion. As a result, players of colour of Test ability were ostracised or simply ignored. ${ }^{91}$

Despite the brevity of the tour, the NZCC certainly made the most of their visitors' time by scheduling three first class fixtures in two weeks, including two tests which were both won by South Africa. ${ }^{92}$ The first match of the tour, a three-day warm-up game hosted by Auckland, began on the same day the South Africans arrived in New Zealand. Immediately after this game, the South Africans travelled to Christchurch where, just two days later they played New Zealand in the First Test. Next they headed to Wellington and three days later played the second test in a frenetic fortnight.

\footnotetext{
${ }^{88}$ Ibid. p. 10.

${ }^{89}$ Christopher Merrett and John Nauright, 'South Africa', The Imperial Game, pp. 55-56.

${ }^{90}$ Christopher Merrett and John Nauright, 'South Africa', p. 56, Dean Allen, 'South African Cricket, Imperial Cricketers and Imperial Expansion, 1850-1910, p. 460.

${ }^{91}$ The two most documented examples were Charles Llewellyn a player from the late Victorian/Edwardian age and Basil D'Oliveira who played in the 1950s and 60s. Llewellyn, whose mother was born in St. Helena played 15 Tests for South Africa but eventually moved to England due to the abuse and 'rampant' provincialism he encountered. Basil D'Oliveira left South Africa to further his cricketing opportunities, represented England, but whose selection - or non selection for the side to face South Africa led to major international intrigue that helped speed the end of sporting ties between the two countries

See Bruce Murray and Christopher Merritt, Caught Behind - Race \& Politics in Springbok Cricket, pp. 4, 14-24 and Martin Williamson, 'The D'Oliveira Affair', Cricinfo Magazine; available from

http://www.cricinfo.com/magazine/content/story/356092.html; accessed 20 October 2010.

${ }^{92}$ For match details see D. O. Neely et. al., Men in White, pp. 131-132.
} 
The New Zealand Free Lance remarked that the South African team's 'stay in New Zealand is such a short one and an expensive one, that the Cricket Council cannot be censured for making as much use of them as is possible under the circumstances. ${ }^{93}$ As with previous Test matches, the games were scheduled for three days, which, if the wicket is true, is generally not long enough for a result. An article in the Dominion echoed the frustrations of previous tours:

It is a great pity that the visit is to be such a hurried one, as there can be little hope of reaching finality in Test matches which are restricted to three days. But I suppose we should be grateful for even this fleeting glimpse of the South Africans. $^{94}$

The writer for the Dominion need not have worried, for the South Africans overwhelmed New Zealand as easily as Australia had defeated South Africa. Prior to the series, New Zealand had reason to feel bullish. Firstly, because the national team had gained more experience from the long tour of England in 1931, and secondly, the South Africans had clearly been rattled by the Australians, and in particular Bradman. Nevertheless, in the first test, the New Zealand bowlers simply could not contain the free-flowing South African batsmen who scored 451. New Zealand in reply only managed scores of 293 and 146 on what was considered a good batting wicket. The star South African bowler was McMillan, whose leg spinners and googlies accounted for nine wickets in the match and showed up the poor technique of the New Zealand players. ${ }^{95}$ The South Africans won the second test by eight wickets despite spirited batting from the home side, in particular Giff Vivian who scored 100 and $73 .{ }^{96}$ For South Africa, Balaskas the 'brilliant young Greek from Kimberly' scored a century in the South African first innings total of $410 .{ }^{97}$

The result of the matches clearly placed New Zealand behind South African on the cricketing ladder and the results were a shock to the country. With opportunities to play a full-strength Australia unlikely, the only way to gauge New Zealand's ability in relation to their Australian cousins was through measuring the relative success of tourists to both countries. The Otago Daily Times reflected, after the first Test defeat,

\footnotetext{
${ }^{93}$ New Zealand Free Lance, 3 February 1932, p. 41.

${ }^{94}$ The Dominion, 10 February 1932, p. 15.

${ }^{95}$ D. O. Neely, et. al., Men In White, p. 131.

${ }^{96}$ Ibid. p. 132.

97 The Dominion, 7 March 1932, p. 11.
} 
that 'the South Africans, though decisively beaten by Australia, were able to win just as decidedly over New Zealand would appear to indicate that there is a tremendous gap between New Zealand and Australian cricket. There seems to be a general feeling that the South Africans did not do themselves justice in the Australia tests in which the amazing consistency of Bradman proved too great an obstacle.... ${ }^{98}$ Apart from simple "bragging rights", such a defeat clearly strengthened Australian beliefs that there was little reason to waste time and cricketing resources on full-length tours of New Zealand. Quite simply, the smaller nation was too weak to invite on tours because they failed to provide a challenge and the potential to become a strong Test nation.

The frustrations of the local media following New Zealand's loss to South Africa were aimed at the usual suspects: poor fielding, poor selection and a lack of quality bowling. H. B. Cameron, the South African captain, when interviewed on 2YA radio shortly before leaving the country, addressed the local criticism, 'there is one matter I wish to refer to especially, and that is do not indulge in or encourage drastic criticism of your Test cricketers, but always remember that they are doing the best for their country.' ${ }^{99}$ Cameron's words appear almost head-masterly, and certainly chiding in their tone towards New Zealand press frustrations at the home team's performance. Although probably a fair statement on the unrealistic expectations of New Zealanders, the fact that a South African captain was essentially fulfilling the role of a wise MCC captain only further confirmed South African cricketing hegemony by the end of the visit.

Radio interviews and newspaper reports were not the only means of communication and connection between the South Africans and the New Zealand public. The imperial ties and casual civility of such a tour were displayed through an evening dance organised for the South Africans and also a concert at the Town Hall in Wellington after the end of the second Test. This concert, in which members of both teams were present, included humorous verses, community singing and also a film of the Australian cricket team in action. ${ }^{100}$ Such events confirmed that these cricket

\footnotetext{
${ }^{98}$ Otago Daily Times, 3 March 1932, p. 4.

${ }^{99}$ The Dominion, 14 March 1932, p. 11.

${ }^{100}$ The Dominion, 7 March 1932, p. 11.
} 
tours, though hopefully competitive, were also importantly about the sociability and conviviality of hosts and guests alike. It was not by accident that cricket was seen as the sport of Empire.

When the South African team arrived in New Zealand in 1932, the racial order of sport in South Africa was already clearly defined. Although the apartheid system which would, from 1948 onwards, make the separation of ethnic groups legally enforceable was not yet in place, the period during which this first tour was undertaken already possessed many of the hallmarks of apartheid. The period 1910 to 1948 is referred to as the 'segregation era': a title which records the fact that during this period the division of land, workplaces and government was not decided simply along black and white lines, but included the division of all ethnic groups within South Africa, including Malays and Indians. ${ }^{101}$ When one considers this division along ethnic lines, and the clear racial exclusion in national sports and society, South Africa's negativity regarding Duleepsinhji's selection for England in a series against South Africa is clearly understood. His selection would undermine the perceived racial superiority and hierarchical assumptions built into sport in South Africa. The fact that the MCC dropped Duleepsinhji confirms white South African unease at this player's inclusion, and also the 'white solidarity' between these two cricketing and imperial nations at this time.

Race and sport became an issue of debate in New Zealand during the interwar years, but was focussed more evidently on rugby in regards to sporting ties with South Africa. In the aftermath of the First World War a New Zealand forces team toured South Africa. The team included the ten times capped All Black, Sergeant Nathaniel Wilson, whose parentage was not Maori, but English and West Indian. He had to remain on the boat when it docked at Durban for the match because of South African concerns that the inclusion of a 'Maori' would cause political harm. ${ }^{102}$ Later, George Nepia recalled with understandable pain the scandalous dispatch sent by the South African journalist Blackett to a South African newspaper after South Africa played against the New Zealand Maori in Napier in 1921:

\footnotetext{
${ }^{101}$ Bruce Murray \& Christopher Merrett, Caught Behind - Race \& Politics in Springbok Cricket, pp. 29-30. ${ }^{102}$ Malcolm Mulholland, Beneath the Māori Moon, An Illustrated History of Māori Rugby, Wellington, 2009, pp. 32-3.
} 
Bad enough having to play team officially designated New Zealand natives but spectacle thousands Europeans frantically cheering on band of coloured men to defeat members of own race was too much for Springboks who frankly disgusted. ${ }^{103}$

This incident, and the disrespect the Springboks showed to Te Arawa in Rotorua when they accepted the tribe's formal welcome, but then turned their backs in disgust at having to play a native team while the Maori side was performing a Haka showed the racial animosity. ${ }^{104}$ This episode was followed by the decision to omit Nepia, and fellow Maori, Jimmy Mill from the All Black side to tour South Africa in 1928. This was considered a conciliatory act on behalf of the New Zealand Rugby Football Union towards the South Africa Rugby Union. ${ }^{105}$ The incident would continue to have ramifications including a suggested withdrawal of Maori players from the 1937 South African tour and the growing appeal of rugby league to Maori as the NZRFU continued to ignore their concerns. ${ }^{106}$

The question of whether black boxers should be allowed to compete against white opponents was one of the most visible and published debates regarding race and sport during the late-Victorian era and into the twentieth century. When Jack Johnson defeated Jim Jeffries in 1910, riots in America led to 18 deaths and at least a hundred injured, most of whom were black men who were attacked for celebrating the victory. ${ }^{107}$ At the same time that the South Africans were touring New Zealand, an interesting article was published in the New Zealand Observer titled, 'Should Black fight White?' The article argues that Heine Muller, the German heavy-weight boxer, should fight the best opponent, the black boxer Larry Gains. The author, probably English, argues that 'Coloured men are allowed in our trams and buses and we accord the perfect equality of opportunity save only in boxing. ${ }^{108}$

\footnotetext{
${ }^{103}$ George Nepia \& Terry Mclean, I, George Nepia, London, 1963 (2002), p. 107.

${ }^{104}$ Philippa Mein Smith, A Concise History of New Zealand, p. 230; Malcolm Mulholland, Beneath the Māori Moon, An Illustrated History of Mãori Rugby, pp. 37-39, Charlotte Macdonald, 'Ways of Belonging: Sporting Spaces in New Zealand History', p 284; Greg Ryan, 'Anthropological Football', New Zealand Journal of History, Vol. 34, No. 2, October 2000, pp. 60-80.

105 George Nepia \& Terry Mclean, I, George Nepia.

${ }^{106}$ Greg Ryan, 'Anthropological Football', New Zealand Journal of History, Vol. 34, No. 2, October 2000, pp. 60-80.

${ }^{107}$ Patrick F. McDevitt, May the Best Man Win, p. 66.

${ }^{108}$ New Zealand Observer, 3 March 1932, p. 18.
} 
It is interesting that debates such as this one never transferred to the South Africans cricketers whilst visiting New Zealand. The importance placed on cricket as a contributor to imperial unity, plus the probable lack of knowledge or interest about the barring of coloured cricket within South Africa at the time perhaps account for this. Another factor was the brevity of the 1932 tour. There was little time for the introspection and interpretation that characterized the longer MCC tours. Furthermore, any discussion about race might simply have been seen as an unsavoury distraction from the unique opportunity that the South African visit offered. The fairly typical view of cricket at the time was expressed by 'Matanga' in an opinion piece in the New Zealand Herald, written during the time of the South African visit:

It cannot escape them (foreigners) that cricket is part of the British Empire as a going concern, not merely serving to train typically English youth and to keep its manhood toned for work, but helping also to link the various British units in comradeship. They cannot fail to see that these tours of great exponents of the national game do more than set new standards of play - that they serve a missionary purpose in what to most clean-blooded Englishman is virtually a part of their religion. ${ }^{109}$

At this stage in New Zealand cricket history, there are very few references to Maori and cricket, and certainly few reaching higher honours, although Wiri Aurunui Baker did play for New Zealand against New South Wales in 1923/24. ${ }^{110}$ It is therefore unclear whether the NZCC would have acquiesced to South African demands to drop a player if such demands had been made. Greg Ryan concludes that 'cricket had only a minute impact on New Zealand's indigenous population. Although constituting more or less 10 percent of the population, Maori contributed no more than ten first-class cricketers prior to the 1990s. Of those who appeared before 1914, almost all can be traced to elite New Zealand schools and greater integration within the mainstream of European society. ${ }^{111}$

\footnotetext{
${ }^{109}$ New Zealand Herald, 5 March 1932, supplement, p. 1.

110 There are limited references to cricket being played at Te Aute College from the late $19^{\text {th }}$ Century who produced several first class cricketers; Ryan notes that the first six first-class players who appeared prior to 1920 were all part of urban European society, Greg Ryan, The Making of New Zealand Cricket, p. 92. Wiri Arunui Baker played for Wellington from 1911-1930 for his career details see Lynn McConnell \& Ian Smith, The Shell New Zealand Cricket Encyclopaedia, pp. 15-16. Adam Parore was the first Test cricketer of Maori ancestry in 1990.

${ }^{111}$ Greg Ryan, 'New Zealand', p. 110, see also Greg Ryan, 'Few and Far Between: Maori and Pacific Contributions to New Zealand Cricket, Sport in Society, Vol. 10, No. 1, 2007, pp. 71-87.
} 
James Bennett's research on Maori as 'honorary whites' suggests a drive to promote Maori to this status by both Pakeha and prominent Maori, notably Peter Buck and Apirana Ngata. This was in order to attain equality for Maori not only in New Zealand but also within the Empire. He suggests that Maori achieved a place as 'honorary whites' but such 'enlightenment' certainly did not extend to other nonwhite groups. ${ }^{112}$ Certainly, the South African rugby tour of 1921, and the furore surrounding the telegram sent to South Africa, provide examples of both Pakeha and Maori asserting Maori equality with Pakeha, and indeed superiority to other people of colour. Sir Peter Buck's response was to state that Maori were 'not of negroid extraction, but of Caucasian descent'. The Hawke’s Bay Rugby union declared, 'whoever was responsible for [this telegram] does not know or understand how highly the Maori race is regarded by his Pakeha fellow citizens. ${ }^{, 113}$ Diffusionist anthropology and the notion of Aryan Maori which promoted the indigenous population as a people above other non-white people of the Empire was popular between the 1880s and 1930s - a fact which fuelled anger and much debate within Maoridom regarding their selection, or non-selection, for rugby matches versus South African sides. ${ }^{114}$

The image of Maori by Pakeha was often sentimentalised in the interwar years, with James Cowan and Charles Goldie providing popular yet nostalgic images of Maori, but by the 1930s more realistic and credible images were being created by writers such as Frank Sargeson, A. P. Gaskell, John Mulgan and Roderick Finlayson. ${ }^{115}$ The interest and indeed belief in Maori as an equal partner with Pakeha in the interwar years was apparent in Savage's Labour Party policy, and acted upon when the party swept to power in $1935 .{ }^{116}$ Savage's personal promise to Maori in 1936 was for

\footnotetext{
112 James Bennett, 'Maori as Honorary members of the white tribe’, pp. 33-54.

${ }^{113}$ Malcolm Mulholland, Beneath the Māori Moon, An Illustrated History of Māori Rugby. p. 39, Peter Buck quote originally sourced from New Zealand Herald, 14 Sept 1921, Hawkes Bay Rugby union quote sourced originally from Paul Dobson, Rugby's Great Rivalry: South Africa vs New Zealand, 1921-1995, Cape Town, 1996, p. 49.

${ }^{114}$ Greg Ryan, 'Anthropological Football', pp. 60-80.

${ }^{115}$ Michael King, The Penguin History of New Zealand, Auckland, 2003, pp. 371-373.

${ }^{116}$ Michael Bassett and Michael King, Tomorrow Comes the Song, A Life of Peter Fraser, Auckland, 2000, p. 107, 250, 259; Michael King, The Penguin History of New Zealand, pp. 359-360.
} 
'economic equality with racial individuality', which emphasised the collaborative notion of two races within one people. ${ }^{117}$

Although the South African visit was short, it was an important one for the global cricketing fraternity. The South African visit to Australia and New Zealand was clearly to further sporting ties, but it also was about expanding the communal associations within the Empire. When the MCC sent teams around the globe, the intention was partly to promote English values inherent in the game and to confirm imperial bonds. When the South Africans visited New Zealand it confirmed a shared sporting pastime and gave an opportunity for warm relations. Questions of racial exclusion, whether it be within the South African team or teams playing South Africa, were simply not a matter for discussion; doing so would conflict with the tours' objectives and cause embarrassment for South Africa, in turn undermining the prospect of future tours. That the South African team easily won the matches confirmed their superiority as cricketers, but the tour provided for New Zealand a sporting challenge and a rare glimpse into the expanding sporting horizons of the 1930s. Despite the hope of further tours, the financial cost of bringing a team from such a distance, as well as the advent of the Second World War, meant that South Africa did not visit New Zealand again until 1952-53.

What these tours show us is the malleable nature of attitudes to ethnicity in relation to cricket and Empire. New Zealanders were perfectly happy to accept West Indians and Indians as guests and equals while they were playing cricket. This is because sport was a space where the normal social rules and norms were secondary to the ability to play the game with skill, to the rules and in the correct spirit. When the South African side visited the tour was a celebration of imperial solidarity and the power of the global British identity. Britishness in the context of these cricket tours was a kind of cultural umbrella that could be enlarged to accept non-white people who adhered to the sporting expectations along with white people who shared a British imperial legacy and belief in Empire.

\footnotetext{
${ }^{117}$ Barry Gustafson, From the Cradle to the Grave, A Biography of Michael Joseph Savage, Auckland, 1986, pp. 188-192.
} 


\section{Chapter Two: Following Tradition, Confirming Change - Jardine and Archdale and their teams in New Zealand, 1932- 1935.}

The MCC tour of 1932-33 and the England Women's visit of 1934-35 were tours that held much interest in New Zealand. They were the strongest men's and women's cricket sides in the world both having just conquered their Australian opponents. In New Zealand both teams were praised by the local press for their technique and for their off-field diplomacy. Both teams were also led by strong characters in Douglas Jardine and Betty Archdale, though these two represented differing paths of cricket over the decade. Whereas Jardine's vision involved a scientific and highly calculated approach aimed to crush the opposition, while still retaining the amateur-professional division, Archdale's team meshed the amateur ethos with technical proficiency in order to confirm the worth of women's cricket. This chapter argues that these two tours were cherished by the press as special events because the standing and ability of the players overcame any potential negatives that might have arisen during the tours. The MCC's brand of cricket under Jardine was decreed unsportsmanlike in Australia, though Jardine was unrepentant. The women's side by contrast was playing a game that had been deemed a male domain and therefore risked being masculinised and ridiculed in the press. In both cases the championing of the tourists was at the expense of regard for the local teams who were roundly criticised. This can, in part, be put down to a press that included former players and critics who generally viewed English cricket as the ideal and their own game as a disappointment. 


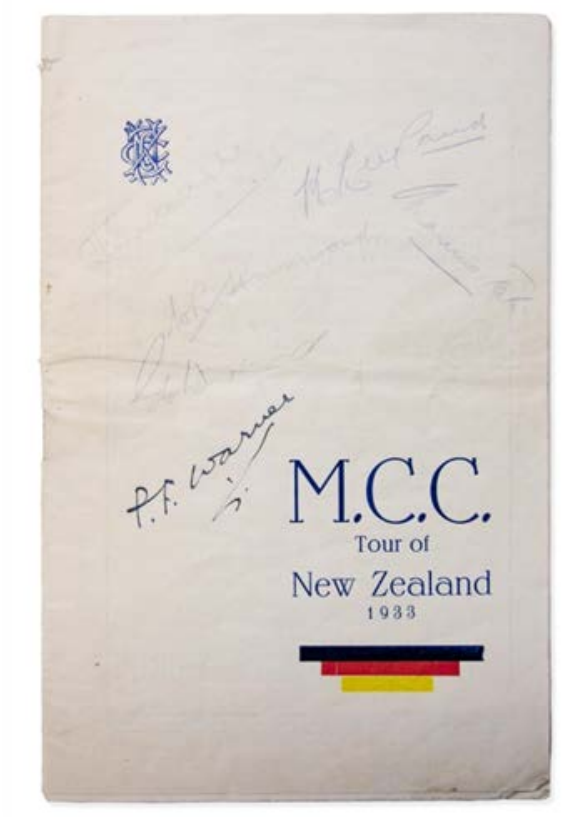

'MCC Tour of New Zealand 1933',

Printed Ephemera Collection, Courtesy of New Zealand Cricket Museum

\section{1932-33}

The MCC arrived in New Zealand having fulfilled their aim of winning back the Ashes in Australia. Although the team was hailed in New Zealand, the storm of controversy over the violent and sustained assault by the English bowlers in Australia was to cast a long shadow over Anglo-Australian relations. ${ }^{1}$ The MCC side could have experienced a much harsher reception in New Zealand - they had infuriated New Zealand's near neighbours with the use of Bodyline bowling and, arguably, even used the tactic briefly in New Zealand. Furthermore, Jardine had developed a reputation for being a difficult and cold personality during his cricket career. The matches were so one-sided that they could easily have been seen as pointless or unfair, particularly as English county and league sides were poaching the best New Zealand talent at the time. Instead the tour was well-received and the matches celebrated by the New Zealand press. The ability of the English players, combined with their star appeal and the perceived educative experience they offered,

\footnotetext{
${ }^{1}$ The Bodyline series saw 25 instances of Australians being hit by the ball, most dramatically when Bill Woodfull, the Australian captain, was hit over the heart in the Adelaide test. This incident and Jardine's apparent lack of concern for Woodfull was the catalyst for a near riot. Ken Piesse, The Ashes, An Illustrated History of Cricket's Greatest Rivalry, Camberwell, 2007, pp. 109-123.
} 
sustained their eminence. Rather than rage against Bodyline tactics, the New Zealand press questioned Australian objections and looked at the tactic with curiosity. Finally, Jardine, rather than appear a sneering arrogant patrician, delivered a series of tactful off-field pieces of diplomacy and generosity in New Zealand. The tour was both intended and seen as an opportunity to celebrate, a shared sporting tradition between 'Home' and New Zealand, while both were distanced from Australia.

New Zealand's understanding of the Bodyline tour as it unfolded was heavily influenced by reports from both the English and Australian press. Coverage and interest was intense. Greg Ryan, examining New Zealand's response to the Bodyline tour, found that editorial comment was broadly pro-British, if not anti-Australian. ${ }^{2}$ Ryan's study showed that the local press accused the Australian press of adopting a 'sensationalist focus' in order to inflame anti-English and anti-MCC feeling. The reports emphasised the belief that the 'incidents' in Australia were a threat to the very fabric of cricket. The New Zealand press also made direct and virulent attacks on Australia and its sporting traditions - focusing especially on the protests raised by $\mathrm{ABC}$ regarding the use of Bodyline tactics. ${ }^{3}$ The sustained nature of New Zealand's anti-Australian responses was, Ryan argues, in contrast to the relative closeness of the two countries, but representative of the strong links with England and deference to the MCC. ${ }^{4}$ When the news broke that the MCC had received a complaint from the ABC about Jardine's tactics, and that the MCC had responded by declaring full confidence in their chosen captain, asserting that no laws had been broken, 'Touchline' for the New Zealand Free Lance wrote:

That is just the position one would expect a body like the Marylebone Cricket Club to take up. They had appointed managers, the captain, and had selected a team in whom they had full confidence, and the protest from the Board of Control got the short shrift it deserved. ${ }^{5}$

\footnotetext{
${ }^{2}$ Greg Ryan, 'Extravagance of Thought and Feeling': New Zealand Reactions to the 1932/33 Bodyline Controversy' in Sporting Traditions, The Journal of Australian Society for Sports History, Volume 13, Number 2, May 1997, p. 41.

${ }^{3}$ Ibid. pp. 41-42.

${ }^{4}$ Greg Ryan, 'Extravagance of Thought and Feeling' pp. 41-58, see Ryan's position on NZ - English relations in Greg Ryan, 'Britishers Anxious to Appear on the Cricket Map', International Journal of the History of Sport, Vol. 25, No. 1, January 2008, pp. 18-40. Also see J. P. Carr, Chapter Six 'The Imperial Connection: International Cricket Relations with England and Australia 1914-1939', pp.123-163 from 'The First Golden Age?'.

${ }^{5}$ New Zealand Free Lance, 1 February 1933, p. 47.
} 
The position of the MCC as international arbiter was indisputable in New Zealand at this time and the $\mathrm{ABC}$ was seen as grossly stepping beyond its brief by a press corps which was clearly pro-MCC.

The New Zealand press and public were curious about the new Bodyline tactic rather than indignant over its use by the MCC. In part, it was seen as a development in the game, and one to which batsmen would have to adapt. The New Zealand batsman C. S. Dempster, in a special article for the New Zealand Free Lance, considered leg theory to be fair, within the laws of the game, and quite playable. He did acknowledge that when he faced what he believed was Bodyline, in a Test match at Lords in 1931, he was hit at least a dozen times on his way to 53. For Dempster, New Zealand's premier batsman of the early 1930s, the English were not trying to deliberately hit Australians; the main problem was that too much attention was being paid to the men fielding on the leg side and not enough to the shot the batsman should play. ${ }^{6}$

The New Zealand response to Australian attitudes to Bodyline can in part be put down to the deference that Ryan rightly suggests was felt for the MCC, but the response was also arguably a retort to the perceived snubbing that New Zealand cricket had received at the hands of Australia. The relationship between the two Dominions had been strained for some time on account of the perceived lack of support from Australia towards New Zealand's cricket development. W. H. Windsor, the Honorary Secretary for the NZCC had travelled to Australia in December 1931 and met with the ABC to thrash out a deal for the MCC tour and for future Australian matches with New Zealand. He argued several points including that it had been forty-five years since an English team visiting Australia had continued on to New Zealand, and that 'Australia had used New Zealand as a training ground for their players as ground and weather conditions closely resemble English conditions. $^{7}$ He was asking for greater solidarity in the approach of visiting teams. The $A B C$ refused to acquiesce and Windsor's angry response was recorded in the NZCC minutes:

\footnotetext{
${ }^{6}$ New Zealand Free Lance, 25 January 1933, p. 46.

${ }^{7}$ Report of W. H. Windsor on interview with Australian Board of Control, included in NZCC Management Committee Book 1922-1934, pp. 282-83, New Zealand Cricket, Christchurch.
} 
I wound up by reluctantly confessing that the Board's decision might probably have the effect of creating a rift in the otherwise good relations that existed between the Council and the Board, and that we would probably have to go further afield for our cricket which would naturally cost us more and deplored the fact that although it was fairly obvious that as far as cricket tours were concerned we should have two if not three visits from Australian teams to one by other sides owing to our proximity and the intimate relationship of the two countries, it would be necessary now for us to carry on without them.

I then finished up with the words referred to in my cable to you on December 30th.

"Board refused cancel any portion Australian programme STOP Informed them we would continue negotiations Marylebone concluded expressing difficulty me [sic] persuade council boards decision both unreasonable and unfriendly." 8

The tour was eventually finalised when space was made by the ABC who rescheduled the end of their leg of the MCC tour itinerary for mid-March and the English County Committees allowed the New Zealand leg to extend into May (including the trip home), despite this meaning their players would miss some matches in England. ${ }^{9}$ Such an act by the Committee and the determination of New Zealand officials to guarantee a visit shows the importance placed on cricket tours between England and New Zealand at this time. Had relations with the Australians been closer, the MCC's performance in Australia and stay in New Zealand may have received more scrutiny and less fanfare.

There is evidence that Bodyline bowling was attempted in the Test match in Christchurch. When Jardine was asked about his tactics on arrival, he announced that 'we will be playing as we played in Australia, but we have lost the spearhead of our attack. ${ }^{10}$ Larwood, the fastest, most accurate and dangerous of the MCC bowlers was over-bowled by Jardine in the final Test of the Ashes series and thus injured. Larwood's best friend, Nottingham teammate and leader of the attack in New

\footnotetext{
${ }^{8}$ Ibid.

${ }^{9}$ NZCC, Annual Report 1933, p. 4.

${ }^{10}$ Auckland Weekly News, 22 March 1933, p. 26.
} 
Zealand, Bill Voce, certainly had the ability to bowl Bodyline or a good-length. As the Otago Daily Times noted, Voce was:

a left-hander with an extraordinary ability to bump the ball. Pitching the ball halfway down the wicket, he made it fly a foot over the batsman's head. He could pitch the ball where he wanted to, and usually he kept it a perfect length. ${ }^{11}$

Greg Ryan argues that New Zealand was not given an opportunity to view Bodyline because the tactic was never actually deployed in New Zealand. ${ }^{12}$ According to Ryan, the New Zealand press failed to 'distinguish between 'leg theory', an attack directed at, or outside, the batsman's leg stump, and Bodyline, an attack directed at the body. ${ }^{13}$ However, the distinction between the two variations was not that great as the remaining fast bowlers lacked Larwood's accuracy, and were bowling on wickets without the responsive bounce required. Therefore, attempts to bowl at the body potentially resulted in more leg side negative bowling than in bowling as intimidating as Bodyline. Even so, the New Zealand opening batsman in the first Test, Paul Whitelaw, in a letter written more than 50 years after the series, remembered vividly Voce bowling leg theory at him:

In Christchurch Voce bowled to me using many more short leg fieldsman - 6 I think - than I had been used to. I batted about an hour and do not remember being hit or the bowling being unduly fast but still it was leg theory and I knew what was coming. Slow bowler Verity gave me more trouble. ${ }^{14}$

Whether or not the MCC did bowl 'pure' Bodyline while in New Zealand is a point of debate. Clearly some intent existed despite New Zealand lacking a batsman like Bradman, whose dominance was the reason for Bodyline's invention, nor was the wicket conducive to the bowling approach. The tactic was employed and continued to be employed because of the English captain's preferences. When Jardine led the MCC to India later the same year he again resorted to brief bursts of Bodyline bowling at unsuspecting Indian batsmen. ${ }^{15}$ Jardine's continued deployment of Bodyline eventually led to his downfall, but while he was captain of England he

\footnotetext{
${ }^{11}$ Otago Daily Times, 27 March 1933, p. 8.

${ }^{12}$ Greg Ryan, 'Extravagance of Thought and Feeling', p 55, also there is no mention of leg theory/Bodyline bowling in NZ in D. Neely et al., Men in White, pp. 133-134.

${ }^{13}$ Ibid. p. 43.

${ }^{14}$ Paul Whitelaw to Lesley Barden, 10/08/1987, Barden, Ledley, fl 1987-1989 letters from cricketers, MS-6778,

Alexander Turnbull Library, Wellington.

${ }^{15}$ Larwood's tour of India reported in Ramachandra Guha, A Corner of a Foreign Field, pp. 199-221.
} 
continued the tactic - to back down would have been perceived as an admission of wrong. He was not confronted about it in New Zealand because of his standing but there was great debate over, and interest in, Bodyline, as it had brought about such a shift in the mindset of cricket players, spectators and officials.

Probably inspired by Jardine's tactics, a rare example of a New Zealander attempting Bodyline came when Don Cleverley, bowling for Ponsonby against Grafton at Eden Park, set a leg side field for the batsman Kerr in March 1933. This happened while the MCC were in Australasia. As reported by The Dominion, his actions clearly earned the ire of the public who in this case were unhappy to see a New Zealander adopt the tactic:

Cleverley's action resulted in an immediate outburst from a section of the spectators from the hill. Although Cleverely was by no means accurate in his leg theory bowling there is no doubt he intimidated some of the batsmen, especially when he bumped the ball occasionally or made it fly over their heads. Cleverley was eventually spelled and when he came on again it was noted he did not bowl to leg field. ${ }^{16}$

It is important not to overplay such an isolated incident but it indicates friction in cricket at this period where notions of fair play were challenged by an aggressive (and potentially dangerous) approach to the game. The outcry by spectators and the short duration of Cleverley's spell highlighted the importance of cricket's established order and the dominance of batsmen as the premier spectacle. That the MCC and Jardine received an overwhelmingly warm response in New Zealand despite their actions in Australia, and the short-lived attempt at Bodyline in the Christchurch Test, indicates the power of the MCC as an image of Englishness and imperial solidarity in New Zealand. It would appear that Bodyline was acceptable or at least tolerated when sanctioned by a captain of England, but not when replicated by a New Zealand contemporary. ${ }^{17}$

Clearly the chief villain for the Australians was Jardine. Bodyline was his invention and legacy and has ensured his name is still linked with infamy. Although a

\footnotetext{
${ }^{16}$ The Dominion, 6 March 1933, p. 11.

${ }^{17}$ Don Cleverley played two tests for New Zealand and was until his death the oldest test cricketer in the world. 'New Zealand/Players/Don Cleverley', Cricinfo; available from http://www.espncricinfo.com/newzealand/content/player/36604.html; accessed 23 May 2011.
} 
representative of the MCC and therefore a distinguished guest of New Zealand, this may not have saved him from taunts had the visit to the Dominion soured. He was a complicated figure, representative of the conservative and traditional values of cricket, yet also forever associated with Bodyline bowling, which heralded a more ruthless, scientific and sustained approach to winning than had been seen before. He was both an establishment figure and a child of the British Empire. Born in Mumbai (Bombay), India, in 1900 he was the son of Malcolm Jardine, a prominent official of the Raj, who became the Advocate-General of Bombay. Douglas was schooled in England at Winchester and then New College Oxford, playing against Cambridge before joining Surrey. ${ }^{18} \mathrm{He}$ was of the correct class and background to be the English captain, but, unlike some first-class amateur captains, he could also bat. In first-class cricket he averaged 46.83 runs and in his Test career 48.00. ${ }^{19}$ Jardine's image in Australia is of an awkward yet determined character and opinion regarding him was divided before the Bodyline series. An article published in the New Zealand Observer a year before the New Zealand tour reported that, 'according to New Zealand players who know him, Jardine is a thoroughly decent chap when one gets to know him but he hides himself behind an aloof reserve that is hard to pierce. ${ }^{20}$

On the journey to Australia for the Ashes series, such was his determination to beat Australia that Jardine began to control the team obsessively. He restricted the time players could sunbathe on the deck, refused to allow them to carry scotch in case they got a taste for it, confiscated golf clubs and checked up on players to find out what time they were going to bed and waking up. ${ }^{21}$ This approach resembles that of a modern professional coach, and sits in contrast to the perception that amateur captains were somewhat genteel and fatherly figures. Jardine may have been an amateur cricketer with a traditional upbringing, but he was also a figure who illustrated the hard-nosed, victory-focussed nature of modern sport - more or less the antithesis of the New Zealand cricket hierarchy of the time.

\footnotetext{
${ }^{18}$ Benny Green (ed.), 'Obituaries' Wisden Anthology 1940-1963, London, 1985, pp. 961-962.

19 'England/Players/Douglas Jardine', Cricinfo; available from http://www.espncricinfo.com/england/content/player/15481.html; accessed 12 July 2010.

${ }^{20}$ New Zealand Observer, 18 February 1932, p. 19.

${ }^{21}$ Duncan Hamilton, Harold Larwood, pp. 136-137.
} 
Upon arrival in New Zealand he spoke at a parliamentary function in the team's honour. He gave this eloquent and diplomatic - rather than strictly honest - appraisal of his relationship with his team after the Australian ordeal:

In the somewhat troublous [sic] time we have had in Australia (laughter) this side has not only been a magnificent machine in the field; it has been a great band off the field. They gave me, their rather sorely tried leader, sympathy and loyalty, without which, frankly I could not have continued. ${ }^{22}$

Jardine, a difficult and prickly figure in Australia, rapidly assumed the role of cricketing diplomat and colonial friend in the more receptive surroundings of New Zealand. He even had time for light banter; when Prime Minister Forbes described the MCC as a British team in a speech at Parliament, Jardine quipped that, 'it is a great pleasure to me, speaking as the only Scotsman in the team, to hear the Prime Minister speak of Great Britain... for months past we have been spoken of in Australia as Englishmen, and I still wince. ${ }^{23}$ The line was clearly meant humorously. In part, his positioning as a Scotsman shows the elasticity of British cultural identity as Jardine was of Scottish heritage, but educated in England and like his father born in India. To a New Zealand audience Jardine was not only eliciting humour but also providing a more human and populist version of his character. When captaining the MCC in India later the same year, he visited the city of his birth, Bombay, and said he was delighted to count himself a citizen by birth of a great city in another crowd-pleasing and Empire-wide gesture of goodwill. ${ }^{24}$

The gathering at Parliament for the MCC's reception in 1933 reveals the intricate off-field machinations which accompanied an Imperial tour to New Zealand. These events provided an official context to the visit and an opportunity for platitudes to be said, recorded and distributed to the Dominion via print and word of mouth. Forbes delivered a speech utterly in line with the expected position regarding New ZealandBritish relations, even if in retrospect it could have left some in the Parliament Building casting sideways looks:

\footnotetext{
${ }^{22}$ Otago Daily Times, 21 March 1933, p. 8.

${ }^{23}$ Auckland Weekly News, 22 March 1933, p. 26.

${ }^{24}$ Ramachandra Guha, A Corner of a Foreign Field, p. 200.
} 
In Australia you met foemen worthy of your steel. After all, however, it is not the winning of the game, but the spirit in which it is played that counts. We in New Zealand want to follow the British tradition that the spirit of the game counts more than the game itself. ${ }^{25}$

Forbes indicated the clear belief in the idealised English/British sporting tradition which he and many New Zealanders felt because of their own identification with English culture and belief in Imperial ties. ${ }^{26}$ Jardine, with impeccable manners, returned the imperial overtures:

Believe me, neither the MCC team nor myself is foolish enough to take this extraordinary kind act of yours in receiving us so soon after our landing as a compliment to us... really, it is a gesture to the Old Country, we take it as such, and when we get home we shall pass it on as such. It is a rare honour and one which will be appreciated by those at home. $^{27}$

Apart from the good-natured official speeches, Jardine and the manager Pelham Warner also visited schools and gave speeches to children about the values inherent in cricket. When Jardine visited St Andrew's College in Christchurch, the school bag-pipe band played as he arrived and the headmaster, A. K. Anderson, delivered a speech which would not have been out of place in a late Victorian school. He stated 'cricket and football in schools are much more than mere games, for they inculcate a spirit of manliness and fair play... and it is a fine thing that the countries of the British Empire are all keen on the game of cricket. Our welcome to Mr Jardine is doubly enthusiastic for the reason that he is an English public school boy and a Scotsman. ${ }^{28}$ J. A. Mangan, best known for his work on the Victorian sports cult argues that 'cricket became the symbol 'par excellence' of imperial solidarity and superiority epitomising a set of consolidatory moral imperatives that both exemplified and explained imperial ambition and achievement. ${ }^{29}$ Such visits to schools further solidified the ideal of Empire in the next generation, dispensed

\footnotetext{
${ }^{25}$ Auckland Weekly News, 22 March 1933, p. 26.

${ }^{26}$ For more on New Zealand identification with England and Englishness see Terry Hearn, www.TeAra.govt.nz/en/english, (accessed 20/3/2010).

${ }^{27}$ Auckland Weekly News, 22 March 1933, p. 26.

${ }^{28}$ The Press, 25 March 1933, p. 12.

${ }^{29}$ J. A. Mangan, ‘Britain’s Chief Spiritual Export: Imperial Sport as Moral Metaphor, Political Symbol and Cultural Bond', The Cultural Bond: Sports, Empire, Society, London, 1992, quoted in Owen Mann, 'The Cultural Bond? Cricket and the Imperial Mission', p. 2201.
} 
English/British values and served to further soften Jardine's image to the New Zealand public.

As well as Jardine, the MCC side was a 'who's who' of England cricketers of the period and therefore a team of considerable gravitas in New Zealand. The indisputable star of the team was Walter Hammond, a prolific scorer of runs throughout his career. During the second Test match of the series in New Zealand he scored 336 in an innings which claimed the record as the highest individual score in a Test match at that time, eclipsing Bradman's previous best. This mammoth effort went with the 227 which he scored in the first Test of the series, leaving the New Zealand bowlers bewildered. Along with Hammond there was the Yorkshire star opening batsman Herbert Sutcliffe who averaged over 60 runs per innings during his Test career, as well as Eddie Paynter and Les Ames, both high class batsmen in their own right. ${ }^{30}$ The team's undeniable star quality drew enormous crowds to the matches. For the warm-up match alone, which was played against Wellington, 17,000 people turned up for a glimpse of Bradman's conquerors. ${ }^{31}$

It is therefore surprising that the Test series was drawn 0-0. As so often transpires, late summer wet weather was a factor and only three days were allotted to each match. Also, although the English batted rapidly, they seemed intent on making huge scores, even if it reduced the time available to bowl out the New Zealand team. The MCC scored 560 for eight in the first Test match and 547 for seven in the second. The inferior, though stubborn, New Zealand batting could never hope to challenge such scores and therefore their only option was to bat to save the match. After the MCC's innings in the first Test the New Zealand Herald reported cheerily:

This was cricket indeed, even if it looked a little one sided. But the English captain was taking no chances of endangering victory: he let his men bat merrily on until nearly a day and a half of the three days' play had passed... to go to that total, in the circumstances, was a compliment to the New Zealanders, even from so grimly determined a leader as Jardine. ${ }^{32}$

\footnotetext{
${ }^{30}$ Herbert Sutcliff's career statistics sourced from www.cricketarchive.com (accessed 15/07/2010).

${ }^{31}$ The Dominion, 23 March 1933, p. 11.

${ }^{32}$ New Zealand Herald, 28 March 1933, p. 8.
} 
Potentially, the English team chose to bat both games into positions where draws were likely because these results would have been more beneficial to New Zealand cricket. From a purely financial point of view, the MCC guaranteed the games went the distance, therefore maximising the gate takings available. Furthermore, this tour, like other MCC tours to New Zealand, was seen as an educative experience, where the main focus was on the star batsmen, and their technique and style.

The short visit of the English team in 1932-33 brought a reasonable financial return for the NZCC. There was a net profit of $£ 1,422$, 3s, $4 \mathrm{~d}$ from the three games, much of which was distributed amongst the affiliated associations. The largest gate receipt was for the first Test in Christchurch where £2,233, 15s, 6d was collected from a crowd estimated to have reached 20,000 when the English were batting. ${ }^{33}$ The large number of patrons and the financial results provided a good stimulus for the game and also an indication of the English cricketers' pulling power despite the tour occurring at the height of economic despair. The Depression should be placed in context. Erik Olssen suggests that as severe as the crisis was, with some 80,000 people unemployed by October 1933, for large numbers of people, 'who had jobs or lived on fixed incomes, life was certainly no worse than it had been in the 1920s and for many it was better. ${ }^{34}$ Additionally, cricket provided a distraction from the more troubling issues of the day.

The New Zealand public who came to the games in their thousands were fairly philosophical about these matches, but they still felt great frustration at their home team's failure to take advantage of the opportunity to test the English team and raise the games above mere exhibition. Cricket for other Test playing nations, notably Australia and increasingly the West Indies, in the 1930s, was an opportunity to not only celebrate imperial unity but also express a sense of national identity through victory over the England side, something which was never achieved by New Zealand. The failure of this team was due to the systemic problems that dogged New Zealand cricket throughout the interwar years. The team lacked a professional base, and the opportunity to develop skills was limited due to the lack of matches. The

\footnotetext{
${ }^{33}$ NZCC, Annual Report 1933, p. 8; NZ Free Lance, March 29, 1933, p. 45.

${ }^{34}$ Erik Olssen, 'Depression and War' in Keith Sinclair (ed.), The Oxford History of New Zealand, Auckland, 1990, pp. 211-216, quote on page 216.
} 
majority of New Zealand players were strictly amateur cricketers with full-time jobs which meant training and matches had to be fitted in around making a living. The inevitable result of this was that the New Zealand players were technically no match for the English. One letter to the editor was hardly complimentary about the New Zealand players' efforts:

What a farce it is at present - ten minutes on each of two nights a week and then we presume to invite overseas teams to try conclusions with us. Of what use are the visits of overseas teams to us if our young men refuse to be stimulated to better efforts. Young men, you may not all be Bradmans, Hammonds, Tates, Oldfields or Duckworths, but it is absolutely certain you never will be unless you practise, practise and MORE practise. $^{35}$

In the Otago Daily Times the frustration of the limited nature of New Zealand cricket in comparison with the English game was articulated after the second Test:

Cricketers who play the merry type of game that our batsmen are forced to adopt in club cricket and who have only three representative engagements in a season can never hope to equal those who devote the entire summer to play first-class matches. Nevertheless, regular visits by English sides can do an immense amount of good for the game in this country. ${ }^{36}$

The English waded into the debate at the end of the tour. Jardine, in the role of cricketing ambassador, attempted to give some balance to the issue of New Zealand's performance:

If I may presume to break a lance with some New Zealanders who appear to me unreasonably critical of their own team's performance, I should remind them that pitted against a side which has toured for five months the home side must necessarily labour under the disadvantage of lacking some of the machine-like efficiency and anticipation which can only come from constant practice and association together. A far fairer and truer index of the real strength of New Zealand cricket would be obtained by excusing the exceptional performances of one very exceptional cricketer. ${ }^{37}$

\footnotetext{
${ }^{35}$ Auckland Star, 6 April 1933, p. 6.

${ }^{36}$ Otago Daily Times, 6 April 1933, p. 4.

${ }^{37}$ Otago Daily Times, 5 April 1933, p. 4.
} 
The New Zealand press never criticised the MCC for batting too long or killing the game but they did criticise their own team for its lack of ability. The frustration with the performances could have ignited another linked frustration: the best New Zealand talent was constantly lost to England, often as a result of playing well against the MCC. For New Zealand cricket there was the very real threat of their best players moving to England to play in the Lancashire professional leagues, County cricket or Julien Cahn's cricketing XI. When the MCC arrived for the 193233 tour of New Zealand the hosts had already lost the recent Test players Ian Cromb, William Merritt, Alby Roberts and Roger Blunt, joined after the series by Stewie Dempster. $^{38}$ The reality was that any New Zealander who performed well was a target to be lured to the Lancashire leagues, which had the money to do so because of the large crowds drawn to games by stars such as Learie Constantine. Frustration at losing the best players was clearly felt by a public who, though not expecting victory, wanted the opportunity for the Test team to represent the total strength of the nation. A letter to the editor in the Auckland Star noted during the Second Test that:

When New Zealanders read the performance put up by the present New Zealand eleven against such a brilliant team, now touring the Dominion, they wonder what would have happened if numerous players who have been poached by English counties and clubs could have been placed in the field. For proof of this we could look at the records of these players on recent tours of England. I wonder how many of the present New Zealand players will soon receive offers of positions in England. Is there nothing that can stop the poaching? It makes me and many others wonder whether tours are of advantage or disadvantage to New Zealand. ${ }^{39}$

The NZCC were unhappy that their best players were being lost to England, and, in Merritt's case, actually suspended him after he broke an agreement signed by the New Zealand tourists to England in 1931 which stipulated he was not to accept English contracts for two years after the tour. ${ }^{40}$ He was reinstated in 1933 , which Greg Ryan argues 'clearly reflected the NZCC's growing awareness of the

\footnotetext{
${ }^{38}$ Only Alby Roberts was to play a test again for New Zealand, (1937 versus England).

${ }^{39}$ Auckland Star, 31 March 1933, p. 6.

${ }^{40}$ Greg Ryan, 'Britishers Anxious To Appear on the Cricketing Map', p. 32. For details of the NZCC resolution regarding Merritt see NZCC MGMT Committee Minutes, December 181931 in New Zealand Cricket Council Management Committee Minute Book 1922-1934, Cricket New Zealand, Christchurch, p. 277.
} 
exceptional economic circumstances of the Depression. ${ }^{41}$ In late 1933 the Chairman of NZCC, A. T. Donnelly, recorded at the Council's annual meeting that it was very hard to stop the best players from furthering themselves:

We could not say to a man whose prospects in life might be limited to some unskilled position; you shall not accept, or become a professional cricketer in this or any other country. That in our opinion would be too great an interference with the liberty of the subject, particularly in times like these. The attitude of the Council always has been to keep our cricket as good as we can get it on an amateur basis, and we tried to keep it on that basis, but we cannot evade the possibilities of some of our players becoming professionals. ${ }^{42}$

The loss of New Zealand players to the English leagues formed part of a larger battle for control of player resources and survival on the fledgling international cricket scene. Lord Hawke, never far from controversy, criticised the English league clubs during the annual meeting of the Yorkshire County Cricket Club:

What is the necessity for the importation of colonial players to the detriment of international cricket? Has the league no pride in birth qualification, and is the cricket success of a club to be dependent on each vying with other as to who can buy the greatest staff? ... No sooner had New Zealand placed herself in the test match arena than three of her most prominent players - Blunt, Merritt and Cromb were taken from her. ${ }^{43}$

In a rather blunt reply $\mathrm{Mr} \mathrm{T}$. E. Morgan, Chairman of the Nelson Cricket Club, one of the most powerful cricket clubs in England and employer of Learie Constantine said:

Lancashire League clubs are out to provide the most attractive professionalism and if economic conditions are such on other countries that a first class cricketer cannot put his gifts to commercial advantage then there should be no complaint if some club offers financial stability. Lancashire League Clubs will continue to conduct the affairs in their own way. ${ }^{44}$

\footnotetext{
${ }^{41}$ Greg Ryan, Ibid.

${ }^{42}$ NZCC, Annual Meeting, 9 November 1933.

${ }^{43}$ The Auckland Weekly News, 15 March 1933, p. 56.

${ }^{44}$ Ibid.
} 
Therefore New Zealand cricket was caught in an unenviable bind. By actively encouraging international cricket through tours, and expressing its commitment to both cricket and the cultural bond with England, New Zealand cricket opened itself to the realities of the international sporting market. Neither financially able to retain its players, nor willing to professionalise its player stock, the NZCC appeared powerless to control the loss of player stock throughout the interwar years. The irony of New Zealand becoming a Test nation and gaining the opportunity of playing test strength sides like Jardine's, is that the exposure and subsequent loss of players actually made these games as much exhibition matches as was previously the case. The performance of Hammond against an underwhelming New Zealand attack simply confirmed the imperial and sporting supremacy of Britain over its former colony rather than ushering a new era for New Zealand cricket. 
NEW ZEALAND WOMENS' CRICKET

COUNCIL

$\rightarrow$

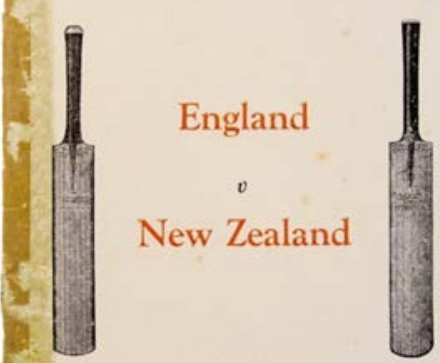

Lancaster Park,

Saturday, February 16th,

and

Monday, February 18th, 1935.

'England v New Zealand 1935',

Printed Ephemera Collection, Courtesy of New Zealand Cricket Museum

\section{The England Women XI}

In late January 1935 an England Women's XI representing the English Women's Cricket Association arrived in New Zealand. The team had toured Australia with success and was infinitely superior to the hastily prepared regional teams and national selection that they faced in New Zealand. Once again for New Zealand, the tour was primarily an educational visit, providing the fledgling New Zealand women's cricket scene with an exemplar of how to play the game and also how to behave as women cricketers. For the New Zealand public the tour was a unique respite from the headlines and gloom that surrounded men's cricket in the aftermath of the Bodyline series. ${ }^{45}$ The tour also represented the continued evolution of world cricket in the 1930s; this was the first ever visit by a women's selection to Australasia. The matches the team played were well patronised and the quality of the cricket played by the English women was of a high standard. The New Zealand press response was positive, though it placed more emphasis on the team's fashion sense and marital status than was the norm for men's teams. The tour exemplified the

\footnotetext{
${ }^{45}$ Rick Eyre, 'Betty Archdale dies aged 92', Wisden, 2001; available from http://www.espncricinfo.com/ci/content/story/88177.html; accessed 29 June 2011.
} 
growing publicity, interest and participation in women's sport in the twentieth century yet also represented the values, beliefs and hierarchical assumptions that characterised the English men's teams' visits to New Zealand during the same period.

The England Women's short visit to New Zealand consisted of seven games, including a solitary test played in Christchurch. The provincial matches were a formality for the England team who beat Auckland by 167 runs, Wanganui by 123 runs and Wellington by an innings and 75 runs. ${ }^{46}$ The Test match was also a severe defeat for New Zealand. The local team scored 44 and 122 in response to England's mammoth 503-5. The England captain, Betty Archdale, somewhat diplomatically and in words similar to Jardine's previously noted, 'we are so much older and a lot more experienced. We have been touring for two months now. We're a hard proposition - much harder than when we arrived in Australia. ${ }^{47}$ Throughout the tour the New Zealand press were phlegmatic about their local teams' chances against such a strong opposition, understanding that there was no shame in losing to such an accomplished side. What criticism there was was directed at the obvious technical shortcomings of the local players. After the Auckland match, the Auckland Star noted that 'the trouble with the batting side of the local team was that few of them had any idea of attacking the bowling and waited for the ball to hit the bat rather than going to meet it. ${ }^{48}$ The writer "Slip" for the Otago Daily Times was rather less diplomatic about the Otago team's efforts and abilities:

The Dunedin women cricketers can never hope to become proficient with the bat until they learn to use their feet at the wickets. The manner in which the Dunedin batswomen reached forward with their bodies, the reaching still farther forward with the bat, to balls well pitched or a little overpitched showed that they had not learnt much about this art of the game. It was not graceful and it was not good cricket. It was very noticeable on the other hand how Miss Hide, of the English team, stepped out to the bowling when necessary and controlled it. The Dunedin girls lost balance by reaching forward as they did, and as a consequence they had to be

\footnotetext{
46 Janet L. Hawes, Women's Test Cricket - The Golden Triangle 1934-84, Lewes, 1987, p. 21.

${ }^{47}$ The Weekly News, 27 February 1935, p. 56.

${ }^{48}$ The Auckland Star, 30 January 1935, p. 16.
} 
satisfied with simply stopping the balls. On more than one occasion they could not even do that. ${ }^{49}$

This inaugural women's tour was representative of a general upswing in the organisation and structure of women's cricket in England during the interwar years. The WCA was founded in 1926 by a group of hockey and lacrosse players who met at the elite Malvern College in Worcestershire. Their purpose was to organise fixtures between the various women's colleges and schools that already played cricket. ${ }^{50}$ According to Archdale, by 1935 the WCA was affiliated with 80 clubs and 80 schools across England. ${ }^{51}$

The WCA was run by women from economically privileged backgrounds. ${ }^{52}$ This is evident in the membership of the team that came to New Zealand and the fact that each member of the team had to raise $£ 80$ to fund the trip to Australasia. ${ }^{53}$ Although the economic downturn impacted on women's participation in sport, there were still opportunities for segments of society to engage in sporting endeavours. Jennifer Hargreaves comments that 'the uneven pattern of poverty and prosperity left by the Depression made it easier for middle-class women and working class women who were relatively affluent or young and single, to participate in sports, than for the masses of poorer working-class women. ${ }^{54}$ The origin of women's cricket dates back to the 1750 s and was initially played by rural women. ${ }^{55}$ The game spread to the aristocratic classes quite quickly with the first recorded game played in 1777 by the Countess of Derby in Surrey. ${ }^{56}$ Women's cricket declined in the nineteenth century as the game was re-defined by the Victorians as an educative component in the exclusive development of young men for service in the Empire. Even so, women cricket enthusiasts clearly persevered, hence the foundation of organisations such as the WCA.

\footnotetext{
${ }^{49}$ Otago Daily Times, 14 February 1935, p. 4.

50 Jennifer Hargreaves, Sporting Females, p. 123.

${ }^{51}$ The Press, 7 February 1935, p. 17.

52 Jack Williams, Cricket and England, pp. 95-96 and 100-101.

53 Adrienne Simpson, 'New Zealand's Wicket Women' in Brad Patterson, (ed.) Sport, Society and Culture in New Zealand, Palmerston North, 1999, p. 66.

54 Jennifer Hargreaves, Sporting Females, p. 113.

${ }^{55}$ Allen Guttmann, Women's Sport - A History, New York, 1991, pp. 77-80.

${ }^{56}$ Ibid.
} 
The WCA was the leading body of women's cricket in the South and Midlands of England, but there were rival bodies with strong working class roots in the north. The Yorkshire Women's Cricket Federation, and other equivalents, had organised leagues consisting of teams entered from the various industrial towns, thereby providing a sharp competitive edge. The notion of leagues and winning trophies was at odds with the ethos of the WCA ${ }^{57}$ Competition was acceptable but playing for the sake of the game was encouraged over professional style competition.

The WCA was an organisation run by women for the development of women's cricket and promoted the finer aspects of the amateur ethos celebrated by the gentlemen cricketers. When the WCA arrived in New Zealand, Archdale outlined the WCA's position regarding the difference between men's cricket and women's cricket and the nature of competition: 'We do not play with men or strive in any way to emulate them, but they have helped us wonderfully in every possible way. We are not touring for the Ashes but to play test cricket. It is very much against the principles of the association to play for trophies of any sort. ${ }^{158}$ Despite such talk from such a refined party, clearly they did not wish to lose to Australia, let alone the minnows from New Zealand. England defeated Australia 2-0 in the three test series before triumphantly arriving in New Zealand on the Wanganella. ${ }^{59}$ The mixture of non-threatening language and measured competitiveness arguably deflected potentially negative attitudes from men towards women's cricket following the crisis in international men's cricket caused by Bodyline.

Betty Archdale (1907-2000) was the most interesting of the players to the New Zealand public. She was born in London educated at McGill University in Montreal, where she graduated in economics, and in political science at London University, having read law and specialised in international law, with studies that involved time in the Soviet Union. Her mother, Helen Alexander (1876-1949) was a leading

\footnotetext{
${ }^{57}$ Jack Williams, Cricket and England, pp. 96-111, see Peter J.Davies, 'Bowling Maiden Over: 1931 and the Beginnings of Women's Cricket in A Yorkshire Town' in Sports in History, 28: 2, pp. 280-298 for further detail on of northern women's league cricket in the 1930s.

${ }^{58}$ The Press, 30 Jan 1935, p. 15.

${ }^{59}$ For analysis of Australian tour see Joan L. Hawes, Women's Test Cricket, The Golden Triangle, 1934-84, pp. 1-20; Deidre Macpherson, The Suffragette's Daughter, Betty Archdale, Her life of Feminism, Cricket, War and Education, Dural, 2002, pp. 96-114.
} 
suffragette who was imprisoned in 1912. Her godmother was Emmeline Pankhurst. ${ }^{60}$ Archdale, emboldened by her mother's experience, epitomised the growing confidence and energy of women across political, professional and public realms.

Archdale, like Jardine, was a strong personality and a disciplinarian with her team and was even jokingly referred to as 'Hitler' within the team circle because of her somewhat dictatorial manner. On tour she didn't set rules per se but made it very clear that if her players misbehaved then they would not be picked for games. ${ }^{61}$ Apart from the fact that the average age of the women's team was 24 and for many of the team this was the first trip away from England, with all the excitement that comes from this, there was the potential for the image of women's cricket to be tarnished by a press eager for gossip and intrigue. Although their time in New Zealand was generally free from incident and the team met with positive responses from New Zealand press, Archdale's qualities as captain were required in Australia when Brian Penton, in his column 'The Sydney Spy' attempted to lampoon her feminist background and the notion of women playing cricket. Clearly attempting to goad her, Penton in his interview was abrasive:

'One has to admit though - you English women are wonderful. Twice as manly - I mean twice as much alive as the men. Don't you think?'

'Do you think so?'

'Don't you?'

'I haven't thought about it.'

Another cold - oh, very cold silence. I thought something might be done with the toreadorical method.

'Anyway', I said, 'I think a women's place is in the home.'

No response.

I observed that in my opinion a women is much better occupied tatting and sewing on buttons than in chasing a ball round the cricket field.

\footnotetext{
${ }^{60}$ Philip Jones, 'Betty Archdale Obituary', Guardian; available from http://www.guardian.co.uk/news/2000/feb/16/guardianobituaries3; 16 Feb 2000; accessed 10/01/2011; see also David Doughan, 'Archdale , Helen Alexander (1876-1949)', ODNB; http://www.oxforddnb.com/index/101058331/Helen-Archdale; first published 2004; accessed Jan 2011; and Deidre Macpherson, The Suffragette's Daughter, Betty Archdale, Her life of Feminism, Cricket, War and Education, Kenthurst, 2003.

${ }^{61}$ Deirdre Macpherson, The Suffragette's Daughter, Betty Archdale, pp. 96-97.
} 
'How very interesting', Miss Archdale remarked, though for a moment, as her eye lighted with a kind of incredulous outrage I thought I was going to get a run out of it. But, no, she tossed her head and simmered out into the garden. In fact we both simmered, for this kind of thing is very irritating to an interviewer. ${ }^{62}$

Archdale and the rest of the England team had their formative years around the end of World War One, a period of political and legal enfranchisement for British women, culminating in achieving the right to vote for women over the age of 30 in 1919 and over 18 in $1928 .{ }^{63}$ Women, particularly those from economically comfortable backgrounds could begin to exert greater influence and take part in a wider range of activities. Nevertheless there was opposition to female encroachment upon male domains such as cricket. When the England team left for Australia and New Zealand The Times noted rather uncharitably:

It does not seem nice to think that they are future mothers charged with the responsibility of setting an example of gentleness, refinement and restraint to the coming generation. $^{64}$

Perhaps emboldened by The Times the team was undefeated on their tour of Australasia. The team itself consisted of seven teachers, two secretaries, two art students, a lawyer and army auxiliary and two women classed as ladies of leisure. ${ }^{65}$ Archdale's team was, according to the team manager, Miss H. E. Green, not a very strong side, in which 'probably only three would find a place in an English XI. ${ }^{66}$ The relative strength of the team had been determined by the fact that the team was only chosen from Association members who could afford to pay their way on the tour. The squad was chosen from the fifty members who had listed their interest in touring. ${ }^{67}$ Betty Archdale was herself a useful batsman as well as a leader who scored runs during the Australasian tour, but she was overshadowed on the field by

\footnotetext{
${ }^{62}$ Ibid. pp. 103-104. Originally sourced from Betty Archdale, 'When Cricket Was Fun!', Chapter IV, p. 10. Brian Penton at the time was a columnist with the Daily Telegraph, of which he became editor. See also Patrick Buckridge, 'Penton, Brian Con (1904 - 1951)', Australian Dictionary of Biography; available from http://adbonline.anu.edu.au/biogs/A150688b.htm; accessed 9 June 2011.

${ }_{63}$ The Representation of the People Act 1918; the Sex Disqualification (Removal) Act of 1919; the Matrimonial Causes Act in 1923; and the Criminal Justice Act in 1925 - info sourced from Robert Graves \& Alan Hodge, The Long Weekend - A Social History of Great Britain 1918-1939, London, 1940, (1995), pp. 46-48.

${ }^{64}$ The Times quote sourced from Jenny Thompson, 'No smoking, drinking, gambling...or men', Cricinfo Magazine; available from, http://www.espncricinfo.com/magazine/content/story/331397.html; 19 January 2008; accessed 10 January 2011.

65 Jenny Thompson, 'No smoking, drinking, gambling...or men'.

${ }^{66}$ The Press, 7 February 1935, p. 17.

${ }^{67}$ Ibid.
} 
the dominant wicket-keeper batsman, Betty Snowball, and the opening batsman and right-arm off-break bowler, Myrtle Maclagan. Snowball hit 189 against New Zealand in the Test match. This remained a world record until 1986. She also achieved several other high scores during the series and formed a formidable opening partnership with Myrtle Maclagan, who, for her part scored 279 runs in the four Tests of the Australasian series (three versus Australia and one versus New Zealand) at an average of 46.50. She was equally impressive as a bowler, claiming 26 wickets at 8.69 runs per wicket. ${ }^{68}$ The performances of these two leading players, and the attitude of the rest of the team, won over the New Zealand spectators and press. They had been initially sceptical about women's cricket because of the poor standard of the local game and the perceived lower skills and physicality in women's cricket. ${ }^{69}$ After the match against Canterbury, The Press noted:

The 2000 odd spectators who saw the match between the touring England women's cricket team and the Canterbury women's team at Lancaster Park yesterday must have left the ground feeling the gap between the standards of men's and women's cricket need be only a small one. ${ }^{70}$

After the Wellington game 'Touchline' writing in the New Zealand Free Lance exclaimed 'They came to sneer, and remained to cheer' and noted that:

Spectators came away with the conviction that cricket was a game that given efficient coaching and good playing conditions, there is no reason why cricket should not improve and become a regular summer pastime for girls. ${ }^{71}$

Their ability and the curiosity of the public meant the matches were very well patronised - 2000 spectators observed the match in Wanganui in which Snowball scored a century. ${ }^{72}$

The scores in the matches showed the disparity between the teams but the majority of matches were drawn with insufficient time for a result. The highest score

\footnotetext{
${ }^{68}$ Statistics sourced from Cricket Archive website www.cricketarchive.com

${ }^{69}$ The Women's Cricket Association believed that cricket must be played from the standpoint of women. With this in view [in England] the boundary was reduced to 60 yards, Harrow style bats used which were lighter and narrower and a five ounce ball was used instead of a standard ball. All were to take into account female physical difference to men. Information sourced from Otago Daily Times, 26 January 1936, p. 23.

${ }^{70}$ The Press, 8 February 1935, p. 21.

${ }^{71}$ New Zealand Free Lance, 13 February 1935, p. 44.

${ }^{72}$ The Weekly News, 6 February 1935, p. 59.
} 
achieved by a home team was by the New Zealand XI when they reached 122 with none of the provincial selections reaching a collective century in an innings. The England team by contrast regularly scored over 200 declared and even 300 on a couple of occasions, plus the 503 scored in the Test match. ${ }^{73}$ The one-sided nature of the contests led 'Old Cricketer' in a letter to the editor to ponder the educative advantage of such tours:

If the present tour is an education one, I am afraid it has not served its purpose, but rather the reverse, for it seems to me the idea of the English team is to beat the local teams by as large a margin as possible, which is not only discouraging and humiliating, but is going to make the local players ask themselves "what's the use". ${ }^{74}$

'Old Cricketer' makes a reasonable argument as the England team did score far more than they would ever need to win, particularly given the length of the games played. So what was the motivation for batting so long? The England Women's approach was to provide an example of how to bat with good technique and to make sure the games went the distance and the public saw a good show. Furthermore, the England team was not, as it said, driven by winning cups, but instead by a desire to play the game itself and was therefore not concentrating on the result as much as the process. The side could have won each game with time to spare but this was an educational venture and was treated as such. An interesting point to note is that 'Old Cricketer' a (presumably male) cricket fan was impassioned enough to write in about the women's match rather than simply ignore the tour.

The failure of the local teams is understandable: they lacked an infrastructure, experience and competition in the local game. Sandra Coney remarks that women had tried organising cricket teams in the 1880s but were met by disapproval because the game was, in people's perceptions, strongly associated with the sports culture of the English public school championing masculinity, competitiveness and gentlemanly conduct. More success was had with hockey. ${ }^{75}$ Greg Ryan notes that women's cricket made its best progress at girls' schools where the game was played

\footnotetext{
${ }^{73}$ For scorecards of tour and averages see 'England Women in Australia and New Zealand', Cricket Archive; available from http://cricketarchive.com/Archive/Seasons/NZ/1934-

35 NZ England Women in Australia and New Zealand 1934-35.html; accessed 10 January 2011.

${ }^{74}$ The Press, 16 February 1935, p. 9.

${ }^{75}$ Sandra Coney, Standing in the Sunshine, Auckland, 1993, p. 248.
} 
before 1900, and was particularly strong in Auckland. ${ }^{76}$ Despite the growth in the youth game, it was not until 1928 that the first provincial association was founded. Auckland took the step forward, quickly followed by Otago (1928), Canterbury (1931), Wellington (1932), and Wanganui and Southland (1933). ${ }^{77}$ Interprovincial cricket soon followed the development of associations with the first representative match played in 1932 when Canterbury met Otago in Dunedin. ${ }^{78}$ The upswing of higher level cricket would suggest a broader uptake in the game. Sue Wightman suggests that women's fitness became a major point of importance in the discourse surrounding motherhood. Wightman discusses a notion of scientific motherhood in which a belief in the improvement of the social body could be developed by improvements in the physical body. ${ }^{79}$ Such attitudes grew in popularity in the 1920s spurred on greater interest in physical activity in general, including sport, and possibly cricket as a means of keeping fit for future mothers.

However, despite this interest the NZWCC itself was only formed with the announcement of the English tour to Australia in 1934-35. The short lead-up period meant there was not enough time to assess the individual players or prepare for the match. This resulted in the near farcical outcome on the morning of the Test match when the New Zealand captain, Ruth Symons, actually had to walk around her team and introduce herself and then ask the players whether they batted or bowled. ${ }^{80}$ The defeat, though impressive, has been contextualised as part of the growing pains in the development of the local game. Adrienne Simpson notes that 'in the aftermath of the 1935 tour there was a huge upsurge of interest in the game. Women flocked to join clubs and many new teams were formed. ${ }^{81}$ The NZWCC strengthened its authority and inclusiveness which had been questioned during the tour. ${ }^{82}$

Canterbury was the initial headquarters for the Council and had the honour of hosting the only Test match. The region was the stronghold of the game and the

\footnotetext{
${ }^{76}$ Greg Ryan, The Making of New Zealand Cricket 1832-1914, pp. 96-98.

${ }^{77}$ Prue Hyman, 'New Zealand Women's Cricket Council 1933-1992', Anne Else (ed.), Women Together, Daphne Brasell Associates Press \& Historical Branch of Internal Affairs, Wellington, 1993, p. 434.

${ }^{78}$ Adrienne Simpson, ‘New Zealand's Wicket Women’ p. 65.

79 Sue Wightman, 'Problem Men' to 'Problem Women': a study of gender in New Zealand, c. 1890 to c. 1930',

MA thesis, Victoria University of Wellington, VUW, 1999.

${ }^{80}$ Ruth Martin (nee Symonds) memory in 'Ruth Martin', Boundary, December 1994, pp. 10-11 referenced in

Adrienne Simpson, ‘New Zealand's Wicket Women’, p. 67.

${ }^{81}$ Adrienne Simpson, , ‘New Zealand's Wicket Women', p. 68.

${ }^{82}$ Ibid.
} 
home of the NZCC. The close Canterbury ties were confirmed by the fact that Dan Reese's wife Esther Parsonson was the inaugural President of the NZWCC. ${ }^{83}$ Not everybody was happy with the way in which the Canterbury Ladies Cricket Association controlled the new national body. A letter from the secretary of the Wellington Association, Miss C. O. G. Robertson, was distributed in response to the NZWCC, demanding 25 percent of the take from the Wellington match (and requiring proof of actual takings):

In regard to your demand for an audited balance sheet of the visit of the English team, your Canterbury Council or Canterbury Association will not receive any such statement from the Wellington Association. I would like to inform your council that the rest of our Management Committee are not so insignificant as I apparently appeared to be to the members of your committee when I was at your last meeting and that they are capable of deciding what percentage the English women's touring team will receive of the Wellington gate. There will be no representative from the Wellington Association at the meeting, and we do not wish anyone to act on our behalf. Thus everything will be just right. ${ }^{84}$

Apart from the sense of being patronised, there was a very real concern that the selection of the New Zealand team would be dominated by Canterbury, unfairly and at the expense of fielding a team truly representative of the country. ${ }^{85}$ In one heated article in the Wellington newspaper, The Dominion, it was suggested that a North Island Women's Association should be formed, leaving the NZWCC to administer the South Island. ${ }^{86}$ Despite bad feelings, the side which took to the field against England was not the Canterbury XI but a team more catholic in selection. The playing eleven consisted of three players from Canterbury, three from Wellington, one from Wanganui, two from Auckland and two from Dunedin. Ruth Symonds from Canterbury captained and, perhaps in an act of reconciliation, the vice-captain was the Wellingtonian, Ina Pickering, though she was injured in the Wellington match and did not play. ${ }^{87}$ Although the team was more inclusive, it had little time to

\footnotetext{
${ }^{83}$ Her husband, Dan Reese, was a member of the NZCC Executive 1908-1929 and president 1929-31, 1935-36) Bernard John Foster, 'Daniel Reese', An Encyclopaedia of New Zealand; available from, http://www.teara.govt.nz/en/1966/reese-daniel/1; accessed 26 September 2010.

${ }_{84}$ Otago Daily Times, 6 February 1935, p. 8.

${ }^{85}$ See The Dominion, 25 January 1935, p. 18 \& Otago Daily Times, 26 January 1936, p. 23.

${ }^{86}$ The Dominion, 7 February 1935, p. 11.

${ }^{87}$ For team listing and cricketing exploits see The Press, 14 February 1935, p. 3. Injury to Ina Pickering see Evening Post, 13 February 1935, p. 6. Ina Pickering married first class cricketer Jack Lamason. She made her Test debut in 1948 which was the next time New Zealand played a Test.
} 
gel on the field and the New Zealanders were crushed in the game. Simpson notes that following the tour, in response to the criticism received, the NZWCC included delegates from all the provincial associations and moved the council around the four main centres to make travel an equal burden. This process ended in 1954 when the Council headquarters moved permanently to Wellington. ${ }^{88}$ The regional differences were in ways similar to the squabbles within New Zealand men's cricket where Otago felt increasingly isolated by the rationalised nature of tours in the 1930s. Perhaps the fear for the North Island associations was not only a loss of representation but also of control of itinerary and therefore future Test matches.

The press coverage of the tour did produce examples of sexist and condescending writing about women's cricket. This reflects the discomfort some men felt about women who were engaging in activities deemed to be traditionally masculine. Most examples are simply patronising rather than abusive or negative. Following the England team's match against Auckland, a writer in the Otago Daily Times noted that:
Even in these enlightened days one is apt to think of women athletes as a rather "Amazon" type, but the match did much to dispel the impression. Even in the task of bowling there was something instinctively graceful about the girls, whose good physique and rhythm of movement were charming to watch. ${ }^{89}$

This style of writing about women's cricket was not confined to New Zealand. Both Peter Davies and Jack Williams refer to the condescension apparent in some of the English press towards the women's game at the same time. ${ }^{90}$ Davies notes the use of the words 'enthusiastic' and 'fair cricketers' in the Brighouse and Elland Echo to refer to women's cricket players in Brighouse, West Yorkshire, when such terms were unlikely to be used to describe the male equivalents in the town. ${ }^{91}$ Jack Williams's view on the English press at the time was that:

Most newspapers gave little coverage to the women's game, and as the press was in the main controlled by men, this

\footnotetext{
${ }^{88}$ Adrienne Simpson, ‘New Zealand's Wicket Women’ p. 68.

${ }^{89}$ Otago Daily Times, 2 February 1935, p. 10.

${ }^{90}$ Peter J. Davies, 'Bowling Maidens Over: 1931 and the Beginnings of Women's Cricket in a Yorkshire Town', Sport in History, Vol. 28, No. 2, June 2008, p. 288-292; Jack Williams, Cricket and England, pp. 103-106.

${ }^{91}$ Peter J. Davies, ibid., p. 289.
} 
probably indicated a male suspicion that the playing of cricket by women was of no great consequence and did not represent a challenge to the social power of men. ${ }^{92}$

In New Zealand it would take a far larger study of newspapers of the period than is the brief for this thesis to support the same assertion regarding the view of women's cricket, but the statement can be broadly accepted. Even so, criticism of or condescension for the women during this tour was outweighed by the positive coverage that the tour received. As Prue Hyman surmises, 'although the more experienced visitors demolished New Zealand in the single test match, the tour was crucial to the development of women's cricket; it also improved the sport's public image, with spectators (at least 3000 at the Wellington game) realising that women could play with true skill. ${ }^{93}$

Another aspect of the tour analysed by journalists was the fashion and style of the England team and their New Zealand opponents. The interest can partially be explained by the growth in sporting leisure-wear as fashion in the 1930s, but was also because of the fascination with the England players. In the match versus Wellington, the Dominion noted that 'the English girls looked every inch cricketers as they took the field at 11 o' clock clad in white shirts, divided skirts, white hats, stockings and shoes. And they play cricket in keeping with their neat and trim appearance. ${ }^{94}$ The England cricketers were noted for their 'Eton crops' (short hair cuts) which, according to the New Zealand Free Lance, made the captain look quite 'boyish'. ${ }^{95}$ Perhaps most interesting is the contrast in styles apparent between the English women and their New Zealand counterparts. As cricketers, the English players showed how to play the game and their dress expressed their conservatism and tradition, particularly in the use of stockings. The Auckland Star noted the subtle difference in styles between the Auckland team and the English:

Smartly dressed in short pleated white skirts and shirts, the players were keenly surveyed when they appeared at the ground. The Auckland team wore regulation cricket caps of blue and short socks, but the visitors completed their dress with white hats and long stockings. It was a scorching hot

\footnotetext{
${ }^{92}$ Jack Williams, Cricket and England, p. 105, quoted in Peter Davies, p. 290.

${ }^{93}$ Prue Hyman, 'New Zealand Women's Cricket Council 1933-1992', Women Together, p. 434.

${ }^{94}$ The Dominion, 6 February 1935, p. 11.

${ }^{95}$ New Zealand Free Lance, 6 February 1935, p. 54.
} 
day, and no doubt the men playing on the adjacent wickets in hotter flannels envied the women the freedom and coolness of their uniform. ${ }^{96}$

While 'Amaryllis' in the New Zealand Free Lance, a broadsheet that took more interest in the players' fashion than other papers, noted that:

The English women in their divided skirts, white stockings and boots, were in contrast to the Canterbury girls; white sleeveless frocks, tennis socks and boots and no stockings. Cricket for women has apparently reversed the stocking habit, for most of the English players are stockingless in the street, but wear them to play in - while we reverse the process. $^{97}$

The England team's player manager, Miss E. Green, was quizzed on the use of stockings. When asked 'why do you retain the old fashioned style?', she replied, 'because it is a rule of our Association'. The reporter further pushed, 'but do you think it looks as smart?' and she replied, 'We think the all-white uniform has the better appearance'. The journalist asked finally, 'are there any practical benefits?', to which she replied 'the straps and buckles of the pads don't touch the skin, and, in places where mosquitoes and other insects are nuisances, stockings are a partial protection. ${ }^{98}$ For the Test match, the NZWCC standardised the uniforms and included the long white stockings that the English wore, instead of the socks that had been worn by the regional sides. Adrienne Simpson suggests this was out of deference to the visitors despite the fact that the New Zealand team thought the stockings were ridiculous in the climate, and 'being forced to wear them was a form of purgatory - especially as they seemed to need continual hitching up. ${ }^{99}$ Although only a small matter, the choice of conservative attire in line with the WCA rules, illustrates deference to the English, and confirms a similar, though less established, version of the relationship already in existence between the MCC and the NZCC.

Despite the severity of the defeats for the local sides the women's tour was the necessary fillip for women's cricket in New Zealand. The prospect of hosting the

\footnotetext{
${ }^{96}$ The Auckland Star, 29 January 1935, p. 8.

${ }^{97}$ New Zealand Free Lance, 13 February 1935, p. 12.

${ }^{98}$ Ibid. p. 59.

${ }^{99}$ Adrienne Simpson, ‘New Zealand’s Wicket Women’ pp. 67-68. Simpson interviewed Agnes Ell in 1998. Ell at the age of 17 played for New Zealand in the 1935 Test match and provides much of the detail on the players reaction to wearing stockings.
} 
England XI led to the rapid development of a functioning national body, which, despite antagonising the northern associations, still managed to assemble a schedule for the tourists and eventually become a truly representative national body. There were examples of sexist or condescending articles in the local press similar in nature to examples from the English press of the time, but, though reflecting attitudes that have long pervaded women's sport, these were nevertheless outshined by positive representations of women's cricket.

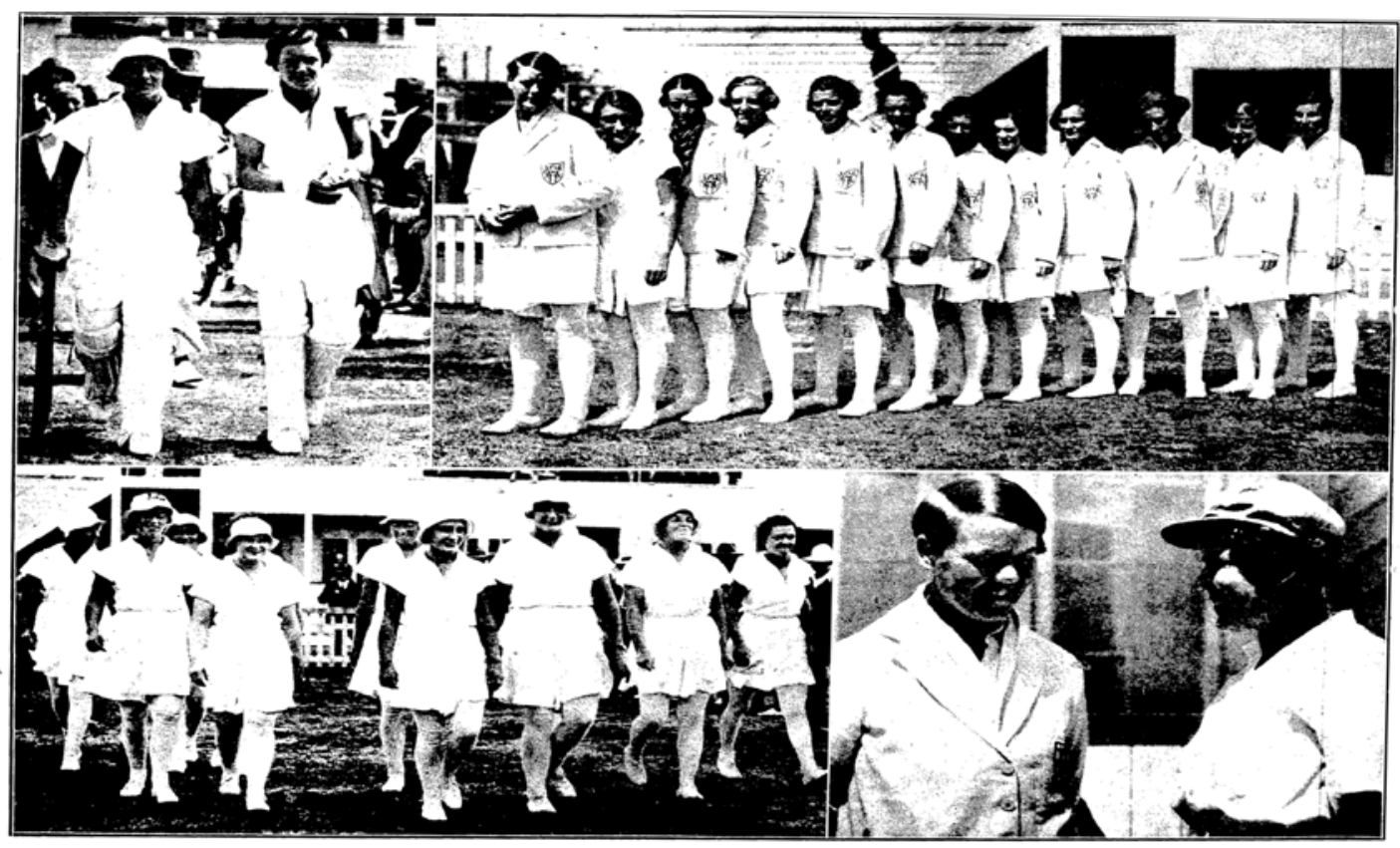

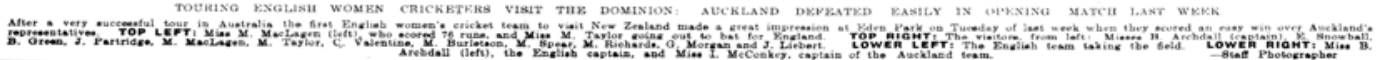

'Touring Women Cricketers', The Weekly News, 6 February 1935, p. 40 reproduced courtesy of the Alexander Turnbull Library

These two tours exemplify the symbolic power of an English cricket tour to a New Zealand public who clearly felt a strong affinity for and association with this British cultural form. Despite the fact that the MCC had caused a firestorm of controversy in Australia, their time in New Zealand was one of celebration notwithstanding the margin of victory, the potential for negativity around the team's tactics and the continued dilution of New Zealand's playing stock. The England Women, playing what was considered a man's game by many, could have been treated with ridicule, but instead were admired and respected for their skill. What is most striking was the civility that is given to the tourists by the press is not extended to the local players. Both the New Zealand men and women were hopelessly out of their depth in their respective matches and were harshly treated by the press despite the obvious lack of resources and playing depth in the local game. The frustration at the apparent decline 
in men's cricket and disastrous beginning to women's international cricket were possibly reflective of a broader anxiety about the direction and development of New Zealand during a time of great economic and social upheaval. While the dominance of the visitors resulted in much consternation in the local press, the visit was also was a source of real pride because of the close association felt by New Zealanders towards the visiting players. The Britishness of New Zealand meant these side were identified as something resembling kin. Therefore their achievements and their stature as players were admired and seen as reflective of the broader strength of Empire.

While the MCC in Australia were remembered for their violent and dangerous tactics they were celebrated in New Zealand for their dominant batsmen, quality bowlers and the relaxed and diplomatic nature of Jardine. While in Australia they exemplified a hyper-masculinity in cricket, the physicality and danger of the game was far less prevalent in their time in New Zealand because it was perhaps not considered so necessary, nor was it so easy to achieve - though still evidenced in small portions. Despite this, the long-term impact of Bodyline meant cricket's future was being questioned. Cricket had been an important aspect of good Empire relations, yet the Bodyline tour had damaged the relationship between Britain and Australia. The timing of the women's tour was therefore beneficial for women's cricket but also for the wider game. When they arrived the England team professed that the game should be played for the sake of cricket and not necessarily for victory. Although not overtly described as such, the less masculine and aggressive nature of this tour was a respite from the way cricket had been heading. Rather than necessarily feminising cricket, the England team represented an attempt to place cricket back within the gentler confines of the international game and assert what such cricket tours were actually meant to represent. 


\section{Chapter Three: What do people actually want from a Cricket Tour? The MCC and Julien Cahn visit New Zealand. 1935- 1939.}

The last three tours of the 1930s were those made by the MCC sides of 1935-36, 1936-37 and the Julien Cahn XI who arrived in early 1939. While the earlier tours of the decade were a celebration of common cultural and imperial bonds, these tours illustrate the sporting and social anxieties of the later part of the decade. This chapter asks the question, what did the players, administrators, press and spectators actually want from a cricket tour? The question arises because these three tours to New Zealand seemed to provoke quite differing expectations and desires depending on who was playing the game, as opposed to watching or financing it. The MCC of 1935-36 and their New Zealand counterparts played a brand of cricket that, although acceptable to the teams themselves, was not acceptable to the press or public who demanded greater efforts and more attacking play. The MCC of 1936-37 had just played a very tough and long Ashes series in Australia. When they arrived in New Zealand they simply wanted to relax and enjoy their stay. They reflected a view of touring New Zealand where the cricket was a poor second to the country's other attractions. By contrast, for the NZCC and public, the chance to play the fullstrength England side was a prized opportunity - even though the poor results led to yet more introspective and gloomy realisations about the local game. Julien Cahn's team also toured New Zealand for the chance of travel, for prestige and potentially even to scout for future playing talent. Cahn's team was not a great side, but its visit was far better received by the New Zealand public than the previous two MCC tours. For a New Zealand press and public facing the possibility of a future war, such a visit was a confirmation of bonds and allegiances in the face of adversity. 


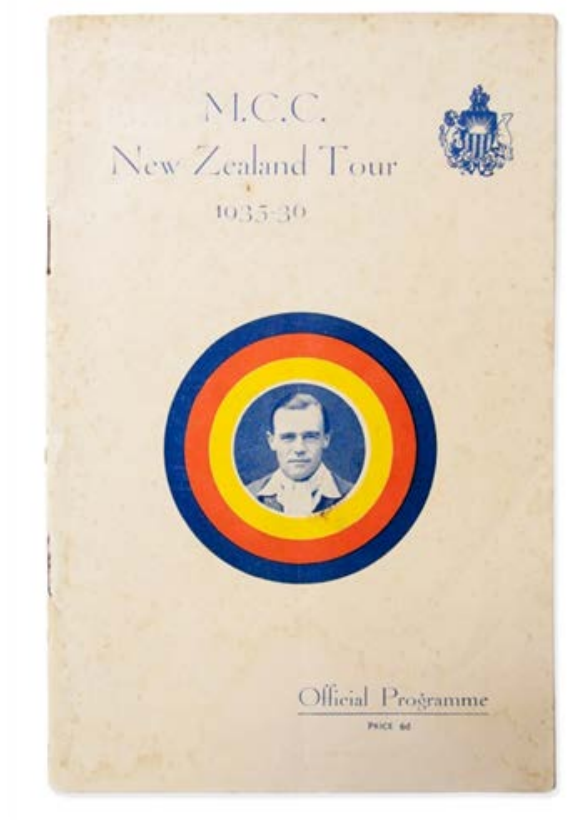

'MCC New Zealand Tour 1935-36',

Printed Ephemera Collection, Courtesy of New Zealand Cricket Museum

\section{The MCC 1935-36}

The MCC team of 1935-36 was selected with an eye for developing the next generation of England Test cricketers. The team, with its seven amateurs and six professionals, was the youngest side that England had ever sent on tour. Only eight of the team had Test match experience and this had been gained mainly against South Africa, hardly a super-power of world cricket, though better than New Zealand. ${ }^{1}$ The MCC in the mid-1930s was blooding new players by matching them against easier teams before selecting them for the rigours of Ashes combat. In the eighteen months before the tour of New Zealand, England had again been humbled by Australia and suffered the ignominy of defeat to both the West Indies and South Africa. These defeats against lower-ranked Test sides were probably the result of the inexperience of the England teams chosen. However, the practice was proving

\footnotetext{
${ }^{1}$ Otago Daily Times, 9 January 1936, p. 10.
} 
unsuccessful and it was reported that 'none of the youngsters tried could be hailed as an outstanding success. ${ }^{2}$

The 1935-36 MCC visit to New Zealand was a very long tour. In addition to an Australian leg, the cricketers were to play eighteen matches in New Zealand, eight of which were first-class fixtures, including four unofficial test matches. ${ }^{3}$ Like the 1929-30 side led by A. H. H. Gilligan, this tour was to venture the length and breadth of the country. Apart from providing cricketing education to the districts such a tour allowed the MCC to experience for themselves the scenic landscape, wildlife and inclement conditions of New Zealand. When the tour ended, Errol Holmes, the captain of the MCC, spoke of his experience: "The tour has been an experience which will last forever in our memories, and we can never forget your hospitality, the friendship, and I must say it, your weather, for in 10 out of 18 games it has interfered with the matches. ${ }^{4}$

The tour was a financial disaster, recording the heaviest loss ever incurred by the NZCC. The initial problem was that the gate takings in Australia were not adequate to cover the expected shortfalls in New Zealand. At the annual meeting of the NZCC later in 1936 it was concluded that the lack of interest in the MCC matches in Australia was because Australian sides toured India and South Africa at the time of the MCC visit, thus reducing the appeal of the spectacle for the Australian public. ${ }^{5}$ Only $£ 532$ was secured for profit to the NZCC from the Australian six match leg. ${ }^{6}$ This was in contrast to the $£ 2456$ of net profit acquired after the Australian leg of the MCC tour in 1929-30, although the expenses were lower for that tour. The NZCC had built up a touring reserve for such contingencies but it meant future profits would have been concentrated on replenishing this reserve, at the expense of developing the game. ${ }^{7}$ The MCC 1935-36 tour exemplified the rift between cricketing orthodoxy and the economic, commercial and public expectations of the time both in New Zealand and England. Cricket and commercial considerations

\footnotetext{
${ }^{2}$ The Dominion, 6 March 1936, p. 11.

${ }^{3}$ Unofficial Test match - meaning the match is a sanctioned first class game but not deemed an official game between the two countries. In this case probably because the England side was not a full strength selection.

${ }^{4}$ Otago Daily Times, 10 March 1936, p. 13.

${ }^{5}$ New Zealand Cricket Council, 'Minutes of 41st Annual meeting of the New Zealand Cricket Council', 6 November 1936, New Zealand Cricket, Christchurch.

${ }^{6}$ New Zealand Cricket Council, Annual Report 1936, p. 7, New Zealand Cricket, Christchurch.

${ }^{7}$ Ibid, p. 3.
} 
were, as Jack Williams has commented, uncomfortable companions for the upper echelons who perceived that a more commercial game would cause a decline in morality. ${ }^{8}$ The amateur elite in England, whether on the field of play or in administration, actively resisted a more commercial approach to the game. Consequently, first-class cricket was run on a financially tenuous basis during the interwar years. ${ }^{9}$ When the 1935-36 MCC team for New Zealand was announced, seven of the team were amateurs, which reflected the continued belief that amateurs provided the best teachers and the best champions acting in the game's interest. At the same time, it was rumoured that they were also chosen in order to minimise the expense of the tour. ${ }^{10}$

During the tour, matches were organised against first-class teams and small associations, as long as they provided a financial guarantee. The schedule led one writer for the New Zealand Free Lance to question the logic of such extensive tours:

Many times I have argued in favour of the country players being given an opportunity of playing against a visiting team like the MCC. But it looks as if the New Zealand Cricket Council went to the extreme in asking the Englishmen to play against Bay of Plenty at Rotorua and Piako at Matamata. These matches gave our visitors an opportunity of seeing the country and that is all that can be said in favour of playing them. $^{11}$

It would appear that profit was not expected from matches against teams as small as Manawatu, but that such games would stimulate enough interest to cover the guarantee. Weather often intervened and in the case of Manawatu with particularly unfortunate results. Not only did a storm rip the roof off the pavilion, soaking the MCC gear and ruining their bats, but the match insurance could not be claimed because technically there had been insufficient rain during the hours of play to activate a claim on the insurance policy. Manawatu lost approximately $£ 150$ on the match. ${ }^{12}$ Months after the tour many of the other clubs had still failed to pay the NZCC the guarantee and in turn the NZCC still owed money to the MCC. ${ }^{13}$ Such

\footnotetext{
${ }^{8}$ Jack Williams, Cricket and England, pp. 161-182.

${ }^{9}$ Ibid. See also Richard Holt, Sport and the British, Oxford, 1989, pp. 286-287.

${ }^{10}$ Neely, et. al., Men in White, p. 136.

${ }^{11}$ New Zealand Free Lance, 26 February 1936, p. 55.

${ }^{12}$ The Dominion, 6 February 1936, p. 11.

${ }^{13}$ NZCC, Management Committee Minutes, July 291936.
} 
financial stress inevitably called into question the benefit of such tours in the development of regional cricket.

The tours were representative of the strong bonds of Empire - but as they were costing more than could be afforded - could that then mean the MCC tour, as an aspect of imperial solidarity, was compromised? The financial burden of long MCC tours did mean that there was a call for the resumption of cricketing tours with Australia that would be far less financially onerous. A shift for financial reasons may have suited the cash strapped regions, particularly if Bradman was attained for such tours, but for the NZCC, the MCC were still the preferred tourists because of their imperial, social connections and prestige.

The team was met by political leaders, including Peter Fraser, in Michael Joseph Savage's absence. They also fulfilled the varied off-field obligations and social expectations. The tour began with an unexpected and thrilling loss to Wellington by 14 runs. This provided the MCC side with an opportunity to display the sense of fair play and amateur chivalry considered essential for English cricketers. ${ }^{14}$ A few weeks after the upset win E. R. T. Holmes, the English captain, wrote an open letter to the Wellington captain J. R. Lamason:

Just a line to thank you so much for the game we played against you. It was easily the most thrilling match we have had on this tour, and we all thoroughly enjoyed it. The fact that you beat us did not upset us so if you consider that it has done some good to your cricket locally we shall all be satisfied. You thoroughly deserved to win and I want to congratulate you personally once again on your success. Hoping to play against you in the New Zealand match yours sincerely (signed), Errol Holmes. ${ }^{15}$

The magnanimous Holmes, while clearly in a gracious mood, was unlikely to want to continue drafting such letters on the tour, but his act represents the civility expected of such sporting trips. Holmes, like Jardine, was born in India, educated at Oxford and captained Surrey, but Holmes' captaincy at Surrey was associated with repairing the damage done by his famous predecessor rather than continuing that

\footnotetext{
${ }^{14}$ See Jack Williams, 'The Really Good Professional Captain Has Never Been Seen!': Perceptions of the Amateur/Professional Divide in County Cricket, 1900-39, pp. 429-449; Jack Williams, Cricket and England, pp. 74-89.

${ }^{15}$ Otago Daily Times, 21 January 1936, p. 10.
} 
legacy. His obituary credits him with attempting to confront the negativity of cricket in the 1930s and the tendency for batsmen to "play for keeps", meaning playing defensively. ${ }^{16}$ His selection as captain of the MCC side in 1935-36 made clear that this was a good-will tour, and that the intention was to play entertaining cricket. Sadly, as we shall see, the tour itself was not distinguished by free-flowing cricket, but instead a mixture of defiant and stodgy batting, conservative captaincy and inclement weather.

The rain clouds that seemed to follow Holmes' team wherever they played were undoubtedly a factor in causing the many drawn games but not the sole reason. In the first Test, New Zealand managed a paltry 81 runs on what appeared to be a good wicket. The MCC, in response, scored 653 in 114 overs. Then, with New Zealand standing on 205-7 in the second innings, the rain came, and the English ran out of time to bowl New Zealand out. It is not clear why England felt it necessary to score such a massive first innings total when it is patently clear that New Zealand was not equipped to reach half that score. One reason for batting so long might have been to ensure that the game went the distance, thereby helping to maximise the allimportant gate takings. There is, however no evidence that this was discussed. A further explanation might be the dominant place of the batsman in the psyche of the game. The crowd wanted to see the Englishmen bat, because batting was seen as the purest part of the game, and was associated most with the amateur ethos. A writer using the initials N. C. L. wrote rather wistfully in the Dominion during the MCC match with Wellington:

If we could look through the spiralling smoke of our pipes, cigarettes and Christmas cigars across the soft green grass to the immaculate wicket and see our visitors charm a great score from the beneficent surroundings with the graces of their bats, then we would indeed be happy. ${ }^{17}$

The cold reality of the Test match was that by batting for so long in order to create such a vast lead, the opportunity for an outcome was clearly reduced. If the MCC had scored 250 and declared, it would have been enough for them to be in control of the match and have given spectators like N. C. L. some watching pleasure. Equally

\footnotetext{
${ }^{16}$ Holmes Obituary, Wisden 1961, p. 947.

${ }^{17}$ The Dominion, 23 December 1935, p. 8.
} 
and sportingly, such a declaration would have given the New Zealand side a chance of forcing their way back into the game, and it would have provided the paying public with a contest as well as the chance of a winning outcome. Thus, those keen on the aesthetics of English amateur batting, and those on eager to see competitive cricket, could both have been catered for.

In the second Test it was New Zealand that was in the ascendant after scoring 242 runs in the first innings and then bowling out the MCC for just 156 runs. In New Zealand's second innings the team scored 229-3 leaving the MCC needing 316 runs to win with just three hours remaining. The MCC grimly held on, scoring 130-7 in 59 overs and thereby saved the game. In hindsight New Zealand's captain Cromb had batted too long in order to make the game 'safe' rather than go for the win. Even so, Ces Dacre, who had been a prominent first-class cricketer for Auckland and Gloucestershire and had represented New Zealand in football, was left fuming at the end by the perception that a draw was a success. In the Weekly News he wrote:

At the present time we are really badly off for a good captain. We need a leader who will take a justifiable risk for victory, no matter what there is at stake. Cricket is only a game and we must always treat it as so, otherwise it is not worth playing... In my opinion, New Zealand should have declared the innings closed at two hundred and fifty. This would have given at least another half an hour in which to get the tourists out. For any side to score three hundred runs in the Basin Reserve in three hours, is next to impossible. ${ }^{18}$

The third Test was a high scoring draw on a comfortable wicket at Eden Park in Auckland in which the New Zealand Truth pointedly suggested that 'the laborious tactics of the Englishmen on Monday gave the spectators the willies, and few were sorry when an unedifying exhibition of cricket petered out. ${ }^{19}$ Little was expected of the fourth Test in Christchurch where The Press stated that the 'wicket is no more likely to provide a definite result in three days than the wickets at Dunedin, Wellington and Auckland, but it will be no mean achievement if New Zealand can avoid defeat. $^{20}$ New Zealand played well, leaving the MCC with a deficit of 139 runs after the completion of the first innings. In their second innings the MCC

\footnotetext{
${ }^{18}$ The Weekly News, 29 January 1936, p. 61.

${ }^{19}$ New Zealand Truth, 4 March, 1936, p. 5.

${ }^{20}$ The Press, 5 March 1936, p. 16.
} 
ponderously reached $142-2$ in 58 overs and were looking to survive, before rain again ended the match early. ${ }^{21}$ This style of play by the English in the second innings aggravated the crowd who were clearly expecting some end-of-tour entertainment. The slowness of the English batting led to increasing hoots and calls from the crowd and with seven minutes to go a spectator jumped over the rails and wandered over to the pitch, presumably to remonstrate with the players. He was eventually convinced to leave the field of play by the New Zealand captain Cromb. It must be noted that this man's actions and the continued crowd annoyance directed at the MCC was highly unusual behaviour at a cricket match in New Zealand or elsewhere. $^{22}$

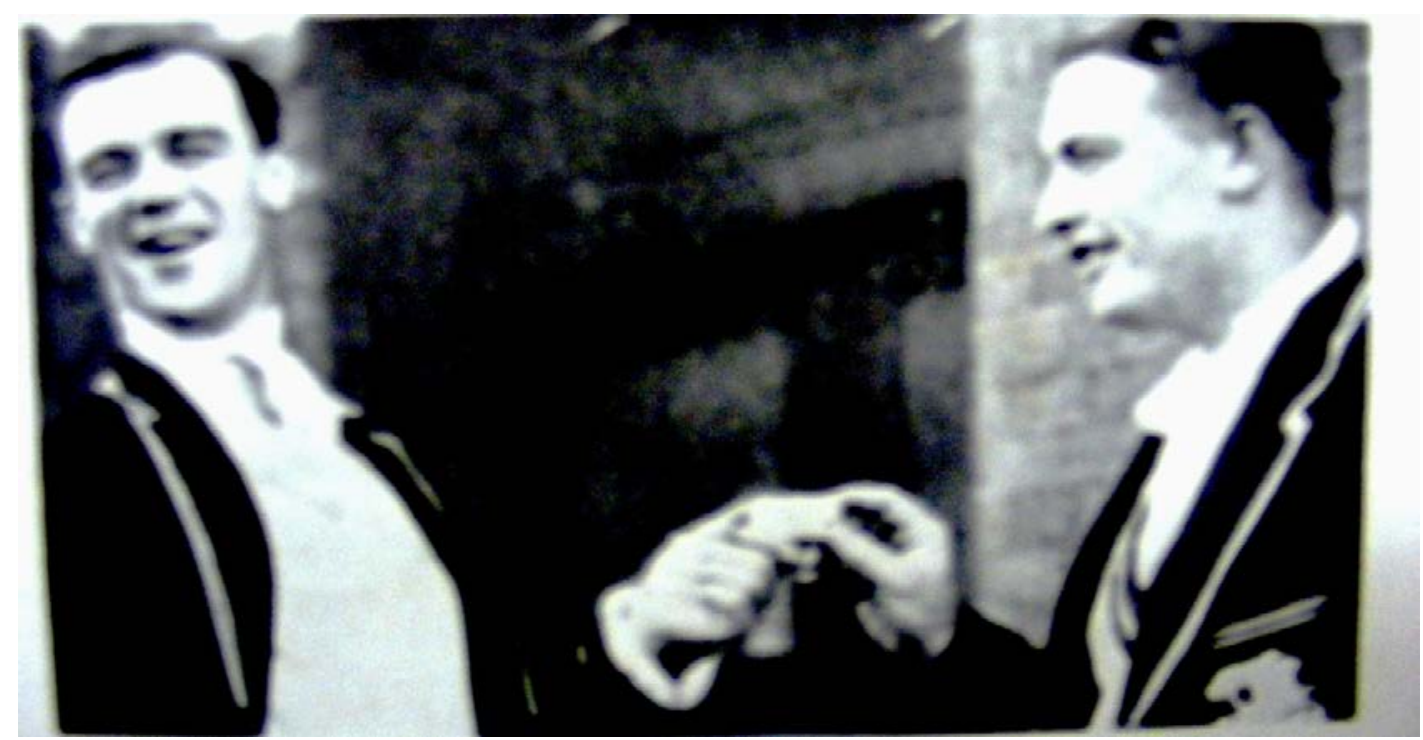

Errol Holmes (captain) and Charles Lyttelton (vice-captain) receive a present during their visit to New Zealand. Image reproduced courtesy of Programme Collection, New Zealand Cricket Museum

The expression of displeasure was unusual for New Zealand crowds but reflected the larger pressure on cricket, and sport in general, to become more entertaining. In England the first-class cricket circuit was run without a great degree of care or concern for the interest of the crowd. ${ }^{23}$ Pelham Warner, who was the manager of the MCC side in 1932-33, would have been shocked and disapproving of the New Zealand spectator advancing onto the field to demand entertainment. His view on the relationship between cricket and public expectation was that the game was 'not a circus and it would be far better that it should be driven back to the village green...

\footnotetext{
${ }^{21}$ Neely, et. al, Men in White, p. 138.

${ }^{22}$ The Press, 9 March 1936, p. 7, the incident is also recorded in Evening Post, 9 March 1936, p. 16. See Allen Guttmann, Sports Spectators, New York, 1986, pp. 101-104 for discussion on crowds at cricket matches.

${ }^{23}$ Richard Holt, Sport and the British, Clarendon Press, Oxford, 1989, p. 286.
} 
than yield a jot to the petulant demands of the spectator. $^{24}$ Despite such a conservative reaction to what were perceived as boorish public demands, there was clearly a need to freshen up the game in the interwar years or further risk alienating and reducing the potential paying public. There had been some changes, notably the LBW law was amended in 1935 making it harder for batsman to simply pad away deliveries. ${ }^{25}$ Overall, though, the amateur elite who controlled the game, and many of the leading amateur players, resisted what they saw as an attack on the very nature and art of cricket by forces unsympathetic to the origins of the game. Tom Lowry, ${ }^{26}$ a New Zealander thoroughly imbued in the amateur principles and traditions, lamented the apparent pressures to play attractively and noted when he was in England in 1937 that:

Newspapers all over the world spend much space in trying to encourage us to play brighter cricket, but they are setting their standards on Bradman at his best and educating the public to that high standard of efficiency that we ordinary cricketers cannot possibly reach. That and the wireless are no doubt driving numbers of people from the game. ${ }^{27}$

Lowry's words of concern echo the ongoing difficulty in finding a way to play the game that would result in an attractive display but not lead to disastrous results because of the inability to play defensively when needed. ${ }^{28}$ In the 1930 s conservative captaincy was accompanied by wickets that were not conducive to bowlers. On the occasions when ball did dominate bat in the 1930s it was either at the expense of fair play, and potentially dangerous (as seen in the Bodyline series), or through the weakness of the emerging Test nations' batting stocks. For C. L. R.

\footnotetext{
${ }^{24}$ Pelham Warner quoted in Richard Holt, Sport and the British, p. 286.

${ }^{25}$ Jack Williams, Cricket and England, p. 165. There were also experiments with the ball in 1927 and size of wickets in 1931 according to Williams.

${ }^{26}$ Greg Ryan notes that Lowry was as close as NZ gets to an amateur Englishman cricketer. Lowry was a wealthy Hawke's Bay sheep farmer, educated at Christ College, won a cricketing blue at Cambridge, which he captained in 1924, his sister married England captain Percy Chapman. Greg Ryan, 'Britishers Anxious to Appear on the Cricket Map' IJHS, Vol. 25, No 1, January 2008, p. 25.

${ }^{27}$ The Times, 7 May 1937, p. 6, originally quoted in J. P. Carr, 'The First Golden Age?', p. 161 and Greg Ryan, 'Britishers Anxious to Appear on the Cricket Map', p. 30.

${ }^{28}$ It is important to note that although this tour resulted in negative draws that reflected much of the cricket at the time the New Zealand team was renowned on tour for their enterprising and attractive play, in contrast to their timid and conservative fashion at home. Both the 1927 and 1931 tours were on-field successes with victories achieved over first-class sides and respectable draws against England. Even the 1937 tour, though not as successful as the previous tours still resulted in some victories for the New Zealand side, in contrast to the draws and defeats that marked their play at home. Such difference in play can in part be put down to player anxiety in front of home crowds and the lack of work distractions when on tour. The poor results and negative play at home might also be a result of the fear of losing impacting negatively on the financial success of the tour. But also, the excessive deference given to touring teams from England, combined with the negative style of play that English teams displayed in Tests, may have had a stultifying influence on the New Zealanders' style of play. For greater analysis See J. P Carr, 'The First Golden Age?', pp. 145-150, 153-158.
} 
James the spirit of the game was lost in that decade. He noted that 'luckily the war put an abrupt end to cricket as it was being played in the thirties. ${ }^{29}$ Cricket was still popular, but clearly there is a link between low gate revenues and tedious cricket. There had been little drive to change the game until the Findlay Commission was set up by the MCC in 1937 to investigate the financial insecurity of county cricket. Sporting philanthropists, like Julien Cahn, had bankrolled English county teams that would otherwise have been insolvent. ${ }^{30}$ In New Zealand cricket there were no saviours who could remove the financial instability that continued to bedevil the game until the 1970s.

New Zealand cricket was not completely amateur, as professional coaches came from England and there were a small number of professionals who played and coached simultaneously at first-class and club level. The cost of their services, combined with New Zealand cricket's ambivalence regarding professionalism in sport, made the English coaches a target for criticism when the local game struggled and matches were played in a negative fashion. ${ }^{31}$ At the end of the MCC 1935-36 tour, Ces Dacre questioned the purpose of coaches while continuing the debate about what was the distinctive New Zealand game:

We in New Zealand who love a game of cricket are, to a certain extent natural players. The English coaches have taught us too much about covering up and using our pads. Do we ever see now that beautiful cut down to third man that we used to see a few years ago? The cut is practically a lost shot. Why? Largely because English professionals have been telling us to let the ball go. This is not our natural game in New Zealand. Most of us were natural players and used the bat to a ball just outside the off stump. What happens to-day? The ball is just wasted. The batsman lets it go by. When I first went to England I did not know what a pair of pads were meant for, but after a few matches I soon found out. In England, the pads are the first line of defence. If a batsman

\footnotetext{
${ }^{29}$ C. L. R. James, Beyond a Boundary, p. 253.

${ }^{30}$ Findlay Commission: a commission set up by the MCC to explore the difficulties of counties taking part in the County Championship. Headed by William Findlay, MCC secretary 1919-1926. see 'William Findlay Obituary', Wisden Almanac; available from http://www.espncricinfo.com/wisdenalmanack/content/story/155510.html; 1954; accessed 25 April 2010. For more detail on economic realities of English cricket see J. A. Schofield, 'The Development of First-Class Cricket in England: An Economic Analysis', The Journal of Industrial Economics, vol. xxx, June 1982, no. 4, pp. 337-360; reference to Findlay Commission in Jack Williams, Cricket and England, pp. 40-41, 54, 115, 20, 153, 162-3, 166.

${ }^{31}$ Interestingly when South Africa was in New Zealand they remarked that it had been English coaches who had helped raise the standard of South African cricket. In 1932, it was noted in the New Zealand Herald that as many as 45 English coaches were working in the Republic in just one season. New Zealand Herald, 9 March, 1932, p. 14
} 
missed the off ball the pads were always there. This style of play upsets a good natural hitter. We in New Zealand must play for the public. We cannot afford to sit on the splice and let ball after ball go. In England cricket is strictly business and in New Zealand it is played only as a game. ${ }^{32}$

The England captain, Holmes, also questioned the use of professional cricketers as coaches in New Zealand and considered the continued diet of overseas teams touring throughout the country as the best means of advancing the game. ${ }^{33}$ His stance is understandable and in line with his contemporaries who felt that the growth of professional coaches would simply undermine the amateur control of cricket. One of the professional player-coaches of the time, W. E. Merritt, spoke about the failings of the local game. His insights reveal his experiences of league cricket in England:

Some drastic step is necessary to improve the game, from what I have seen in Christchurch this season. One-day cricket would be of great value. The game was meant to be a gay and bright adventure, not the funereal affair it largely is at present. ${ }^{34}$

Although Merritt essentially agreed with the amateurs about the importance of tours:

A tour of England, of course enables cricketers to mix with other players of top form. One can thus imbibe the atmosphere and the traditions of the great game and copy the styles. $^{35}$

A strong contrast can be observed between cricket and the professional and commercial changes happening in other sports of the 1930s. As Barbara Keys notes, the choice of Los Angeles as the host city for the 1932 Olympic Games represented 'a more global game, more competitive, more commercialized and more Americanized version of international sport. ${ }^{36}$ Although the United States did not give the world major team sports, it did develop advanced training techniques and high achievement ambitions which stressed the importance of sporting success, in turn revolutionising the nature of competition in both amateur and professional sports. ${ }^{37}$ One consequence of the development of American sport during the interwar

\footnotetext{
${ }^{32}$ The Weekly News, 18 March 1936, p. 64.

${ }^{33}$ New Zealand Free Lance, 25 March 1936, p. 48.

${ }^{34}$ New Zealand Free Lance, 18 March 1936, p. 51.

${ }^{35}$ Ibid.

${ }^{36}$ Barbara Keys, Globalising Sport, National Rivalry and International Community in the 1930s, p. 91.

${ }^{37}$ Ibid. pp. 64-89.
} 
years was that it engaged more fully in international competition around the globe. The outcome of these ventures was not unlike those claimed for English cricket tours as the 'purported effects of these tours were not limited to advancing sports but also included promoting international harmony and creating favourable impressions of the United States. ${ }^{38}$ In a sense, cricket's unease about a professional future, due to the perceived loss of sportsmanship, meant the standard of play could not be developed in regions that were not wealthy enough to support a strong base of quality amateur cricketers. In the English County Championship, in the first half of the 20th century, there was no cap on the number of professionals that were allowed, and generally northern counties, such as Yorkshire, had a higher proportion of professionals and won more Championships. Essentially, for New Zealand to defeat England's amateurs in the 1930s, they needed to be professional. Although New Zealand's management could not stomach a more professional basis for cricket within the country, let alone afford to finance it, the public certainly would have supported the change if it meant improved results and more entertaining games. In the first Test of the series, in which New Zealand narrowly avoided a huge defeat, it was reported that the local team dropped a barely plausible 15 catches during the English innings. ${ }^{39}$

Cricket remained true to its conservative and amateur roots and only through necessity later in the century were radical changes seen in the sport. The genuine frustration felt by the New Zealand public and press at the spectacle on display was because there were expectations of entertainment and decent performances as befitting a side representing the country. New Zealand had been receiving tours from England teams for decades yet the prescribed educative benefits that such tours were to provide never actually seemed to advance the playing level. For the NZCC and the MCC tourist alike the tours were not necessarily about fulfilling public expectation but about confirming and sustaining relationships between establishment figures and the elite of the two countries.

The MCC 1935-36 tour exemplifies the frustrations within cricket for supporters and the debate surrounding the direction the sport should take. Amateurs had dominated

\footnotetext{
${ }^{38}$ Ibid. p. 78.

${ }^{39}$ New Zealand Truth, 15 January 1936, p. 5.
} 
the administration and captaincy of cricket teams, and arguably did so in the honourable and traditional belief that they were maintaining the essence of the game. The tours had always provided an opportunity for the elite of the colony, including the NZCC, to get close to their social kin from 'Home'; social contact was a major part of such visits. Cricket, though, had long outgrown the ring-fenced and often hypocritical amateur guardians. The New Zealand public, which paid the money that kept the game financially viable, demanded in return more than simply an exhibition of cricket for gentlemen. They wanted entertainment like they were seeing in other sports and they wanted a contest. When the MCC came there was hope that they would provide bright and breezy cricket but a mixture of poor weather and uninspired conservative captaincy, from both sides, meant the tour never engaged the public imagination. 


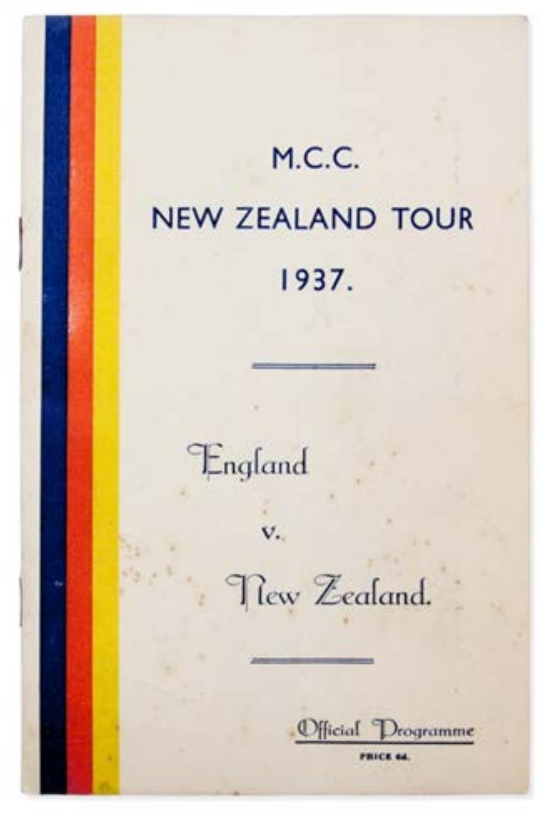

'MCC New Zealand Tour 1937',

Printed Ephemera Collection, Courtesy of New Zealand Cricket Museum

\section{The MCC 1936-37}

The MCC's last tour to New Zealand before the Second World War was a short visit in March-April 1937 after a long and unsuccessful Ashes campaign that began in October and was completed in early March. The team's stay in New Zealand included matches against a combined Canterbury-Otago selection, an AucklandWellington selection and one Test match played in Wellington. For the MCC the visit was, as on other occasions, a welcome holiday and respite after the pressure of 'real' cricket. For the New Zealand team it was a last chance to prepare before their third tour of England. It also gave the New Zealand public a chance to see a fullstrength England side after the disappointment of the previous tour in 1935-36. Because of its prestige as a team selected for the Ashes series, the visit made financial sense. However, from a competitive point of view, the tour would again be a one-sided affair. The England team was vastly superior to the New Zealand selection as regards cricketing skills, though they had just completed an arduous tour. It is therefore hardly surprising that they were not so much focussed on playing cricket as on having a good time. This side, like the other sides to visit New Zealand in the 1930s, was looking for an opportunity to see the scenic landscape, experience 
Maori culture, and partake in hunting and socialising. Furthermore, the MCC side of 1936-37 had departed a nation gripped by internal and external strife. The Daily Telegraph's summation of 1936, reproduced in the Robert Graves and Alan Hodge's Long Weekend, gives an account of the situation that these cricketers left for warmer shores:

It is not that 1936 will be memorable by the magnitude of its actual catastrophes. But it has abounded in events which have seemed to bring catastrophe near. Serious alarms at home, graver alarms abroad, a deepening sense of gathering storm, feverish military, naval and aerial preparations, revolution and civil war have kept Europe continually on tenterhooks... Yet the British people have not escaped affliction. Within a single twelvemonth three Kings have reigned over us... ${ }^{40}$

The situation in Europe and the abdication of Edward VIII were obviously important to New Zealand too. Cricket provided a relief to the realities from the late 1930s though for the England team, cricket had been had been far from a source of relief after a five-month tour of Australia that resulted in an Ashes defeat.

The MCC team that arrived in New Zealand had not only been charged with reclaiming the Ashes, but also had a brief to smooth the damaged relations between England and Australia after the Bodyline tour four years earlier. The burden of winning the Ashes 'well' was carried by the captain, "Gubby" Allen. His disappointment was evident after the loss in Melbourne that condemned his team to defeat. After the game he said 'it is quite apparent that I cannot stand another tour... and probably I am not good enough.' ${ }^{41}$ On the boat to New Zealand, Allen apparently spent his time in his cabin, which led to rumours that he was growing a beard to frighten the New Zealanders. More likely the mentally draining visit to Australia had taken its toll and he was probably sick of cricket and talking cricket. ${ }^{42}$ When the team arrived in New Zealand, Allen and the team manager, Captain Howard, refused to answer questions relating to the completed Australian tour, clearly not wishing to dwell on Bradman's continued dominance over England. ${ }^{43}$

\footnotetext{
${ }^{40}$ The Daily Telegraph, 31 December 1936, quoted in Robert Graves \& Alan Hodge, The Long Weekend, London, 1940, (1995), p. 366.

${ }^{41}$ New Zealand Herald, 18 March 1937, p. 16.

${ }^{42}$ New Zealand Truth, 24 March 1937, p. 5.

${ }^{43}$ Bradman averaged 90 runs per innings in the 1936-37 series.
} 
When broaching the subject of the New Zealand leg of the tour, Allen remarked that the team was looking forward to some 'nice pleasant cricket, free from anxiety. ${ }^{44}$ The pleasant cricket that Allen was looking for was very late in the New Zealand season (March 19-April 3). This timing was unavoidable due to of the length of the Australian tour. Despite the long shadows that would be cast by the late season sun, the visit offered an end of summer celebration for New Zealand cricket. The New Zealand Free Lance noted that:

the Easter holidays usually sound the curfew for the cricket season in this country. Practically the only remaining games of importance are those which will be played by the MCC team and these should prove a fitting finale...

It is hoped... that the Englishmen will be inclined to treat the fixtures more in the nature of the festival matches which wind up the season in their own country. ${ }^{45}$

Once again, inclement weather played its part in this tour, as indeed was the case with most of the tours in the 1930s. Many of these tours occurred at the end of the summer and into early autumn when the weather was more changeable. Unexpectedly, the short tour incurred a small financial loss despite the star appeal of the visitors. The NZCC Annual Report for 1937 notes that not only were gate receipts less than expected but also the cost of bringing the MCC from Australia was much higher than when Jardine's MCC team came in $1933 .{ }^{46}$ The unexpected financial impact of the MCC 1936-37 tour so soon after the financially disastrous MCC tour of 1935-36, and the losses from the tour to England by New Zealand in 1937, meant that the intensive contact with the English had left New Zealand cricket in a delicate position. Short sharp tours like the MCC 1936-37 were meant to provide a financial fillip, as the tour was not burdened with the expensive task of acting as sporting educators around the smaller centres; rather, the games were played in the most populous centres that would guarantee a big crowd at the matches. Furthermore, the team included some of the best players in the world, several of whom were well known to New Zealand from previous visits. The fact that the tour suffered a loss further emphasised the fragility of the sport in New

\footnotetext{
${ }^{44}$ Otago Daily Times, 18 March 1937, p. 10.

${ }^{45}$ New Zealand Free Lance, 24 March 1937, p. 52.

${ }^{46}$ NZCC, Annual Report 1937, Cricket New Zealand, Christchurch.
} 
Zealand, despite the underlying belief in the importance of cricket to New Zealanders' image of themselves as part of the Empire.

The MCC comfortably won the tour matches against the Canterbury-Otago selection and the Auckland-Wellington selection and drew the Test match with New Zealand in sensational fashion. The MCC scored 427, bowled out New Zealand for 265 and had them 158-9, still 4 runs adrift of the MCC's first innings score. New Zealand's last wicket stand managed to gain a one run lead - and therefore make the MCC bat again - before the last man in, Jack Cowie was stumped. At the completion of the New Zealand innings there were only three minutes of time left to play and it was judged that there was not time for the one over England needed to score the two runs required for victory. ${ }^{47}$ Despite the dramatic survival the New Zealand Herald commented:

That the New Zealand cricketers will require to improve greatly before they can hope to challenge the full strength of England was made abundantly clear in the third and concluding day's play between the MCC and New Zealand elevens at the Basin Reserve yesterday. ${ }^{48}$

The English team was a very strong selection including Walter Hammond, one of the premier batsmen of the 1930s, and Hedley Verity, who claimed nearly 2000 first class wickets in the 1930s. ${ }^{49}$ When the MCC played the Auckland-Wellington selection, New Zealand Truth noted that 'most of the Auckland batsmen were beaten before they faced the world famous bowlers'. ${ }^{50}$ However, despite the reputations and obvious ability of the English players, they appeared rather lacklustre in the reports of the matches. After the match against the Canterbury-Otago selection the New Zealand Free Lance noted:

Following the Australian tour, most of the Englishmen seemed to come to Christchurch looking for relaxation rather than serious cricket. ${ }^{51}$

and the Weekly News reflected that:

\footnotetext{
${ }^{47}$ Neely, et. al., Men in White, p. 141.

${ }^{48}$ New Zealand Herald, 29 March 1937, p. 11.

49 'Hedley Verity', Cricket Archive; available from http://www.cricketarchive.com/Archive/Players/0/577/577.html; accessed 12 Sept. 2010.

${ }^{50}$ New Zealand Truth, 7 April 1937, p. 5.

${ }^{51}$ New Zealand Truth, 24 March 1937, p. 5.
} 
One could not expect anything sensational from the MCC team and this was in the nature of a holiday game to them and the majority of them were not taking it very seriously. ${ }^{52}$

These comments were followed up with articles which described the MCC during their short visit as 'stale', 'jaded' and 'stodgy'. ${ }^{53}$ The lacklustre nature of play did not lead to outright condemnation of the MCC side because this team was recognised as the cream of England's players, and it was an honour to have them visit. Clearly, though, there was disappointment from the public who wanted the stars like 'Gubby' Allen to shine in New Zealand. The players were not interested in the matches nor did they rate their opponents. Les Ames, the outstanding wicket-keeper batsman, although at a convivial and light-hearted social event still said with honesty: 'New Zealand seems to be quieter than Australia and the cricket - I don't want to be rude - is much easier. ${ }^{54}$ It was the landscape and natural wonders that New Zealand could offer, along with the friendliness and generosity of the public, that were probably the lasting memories for these tourists, and indeed many of the cricketers who visited New Zealand in the 1930s.

The MCC were in New Zealand from 18 March until till 3 April 1937 with each of their three games scheduled for three days. The Canterbury-Otago and New Zealand matches included a rest day and the tourists had roughly seven non-cricket days for other endeavours. The short stay in New Zealand was part of a much larger journey that was preceded by stop at Ceylon (Sri Lanka) where a match was played and five and a half months in Australia, with twenty six matches played. After leaving New Zealand they sailed to the United States, travelling to New York before they boarded the Queen Mary for the trip across the Atlantic and home. ${ }^{55}$ Ashes tours were massive and exhausting undertakings, in which the motivation levels for the lesser matches would be sorely tested, particularly when there was so much to see and do. During their stay in New Zealand the MCC hunted near the Tasman Glacier, visited the Waitomo Caves, Wairakei, Rotorua, Whakarewarewa and the Fairy Springs. Two of England's most famous players, Wally Hammond and the aforementioned

\footnotetext{
52 The Weekly News, 31 March 1937, p. 66.

53 New Zealand Herald, 5 April 1937, p. 8; New Zealand Free Lance, 31 March 1937, p. 52; New Zealand Truth 31 March 1937, p. 5.

${ }^{54}$ The Dominion, 25 March 1937, p. 13.

${ }^{55}$ New Zealand Herald, 5 April 1937, p. 12.
} 
Les Ames, even missed a game in order to have a fishing trip to Tauranga. The team manager, Captain Howard, stated near the end of their stay: 'we have been greatly impressed with the scenery we have been privileged to witness in both the North and South Islands. ${ }^{56}$ For this side and the other teams that visited New Zealand, the chance to visit in New Zealand's 'Northern Wonderland' and walk tracks on the Southern Alps was an exciting and dramatic tourist experience.

Tourism in New Zealand had been an important focus of government since the late nineteenth century, but became even more important after 1901 when huge sums of money were poured into the baths, gardens and a model pa in the thermal regions of the North Island. ${ }^{57}$ In the South Island there had been less direct funding, yet the construction of the Hermitage and introduction of wild creatures for hunting, such as deer and trout, hint at the ambition as well as the type of tourism envisioned for the 'southern wilderness. ${ }^{58}$ Like New Zealand cricket, tourism in New Zealand in the first half of the twentieth century was a financially fraught affair, yet investment continued. In 1926 the Waitomo caves had electric lights installed, and the Otira Tunnel was opened which meant it was possible to travel by rail between Christchurch and the West Coast (Greymouth) in a day. ${ }^{59}$ However, the Depression hit tourism hard, particularly as it was already struggling to turn a profit in the 1920s. Tourism offices in Greymouth and Nelson were forced to close in the early 1930s, patient services at the health spas of Rotorua were cut back and even the normally viable Waitomo Caves experienced a huge decline in profits and visitors. ${ }^{60}$ The industry bounced back once the worst of the Depression was over, and in the 1935-36 tourist season a record number of visitors were recorded. ${ }^{61}$

Apart from the scenery, hot pools, hunting and fishing that cricket teams and tourists alike experienced, the trip to New Zealand provided social activities that encouraged relaxation. The 1936-37 MCC team were honoured with a Government reception on

\footnotetext{
${ }^{56}$ New Zealand Herald, 31 March 1937, p. 16 and 1 April 1937, p. 14.

${ }^{57}$ Margaret McClure, The Wonder County - Making New Zealand Tourism, Auckland, 2004, pp 47-49.

${ }^{58}$ Ibid. pp. 52-56. \& 65-91.

${ }^{59}$ Robert Arrell, Waitomo Caves - A Century of Tourism, Waitomo Caves Museum Society Inc, Waitomo Caves, 1984, pp. 39-43, Margaret McClure, The Wonder County, pp. 94-95.

${ }^{60}$ New Zealand Tourist and Publicity Department, 75 Years of Tourism, Wellington, 1977, p. 8; McClure notes that by 1920 Waitomo was the only government resort to be consistently profitable, Margaret McClure, The Wonder County, p. 107.

${ }^{61}$ New Zealand Tourist and Publicity Department, 75 Years of Tourism, p. 9.
} 
arrival; they enjoyed a Maori evening concert during their time in the Bay of Islands; were the guests of honour for a dinner held by the NZCC; and attended a "five to seven" party in which 'the reception rooms were decorated with bowls of mixed flowers. ${ }^{62}$ There was even time for the Yorkshire Society of New Zealand and the Society of Men of Kent and Kentish Men, to entertain the MCC players born in those counties at the St George Hotel in Wellington. Karl Atkinson, President of the Yorkshire Society, excitedly introduced the esteemed visitors, 'tonight we have a bit of old England with us and we welcome men who have shed lustre on their respective counties. ${ }^{63}$

Malcolm MacDonald, the Secretary of State for Dominion Affairs, addressed the New Zealand Group of the Overseas League at a talk in London at the same time as the tour. Occasions like the one in the St George Hotel must surely have been what he was hinting at when he said to the group:

There is no reason under the sun why we should not go through the years, generations and centuries together as we have in the past. The most effective way of maintaining harmony and unity is not by dispatches sent by Secretary of State or by Government department decisions, but by the multiplicity of informal gatherings in which we can exchange our views, remembering that it is good to belong to this Commonwealth, that we are the same flesh and blood, and that the best we can do for ourselves is to continue in this unity for the years ahead. ${ }^{64}$

A cricket tour to New Zealand in the 1930s provided a great opportunity for English cricketers to explore a corner of the Empire which, although remote, nonetheless catered for tourists, and had, now, decades of experience entertaining cricket teams from overseas. These experiences were recorded in the players' tour journals and published accounts.

The accounts give an insight not only into the types of activities that were offered to the sporting visitor but also into the mindset of the players themselves. What comes across in their reflections is the emphasis on Maori culture as part of a tourist

\footnotetext{
62 The Dominion, 18 March 1937, p. 18; New Zealand Herald, 31 March 1937, p 16; The Press, 22 March 1937, p. 15; The Dominion, 25 March 1937, p. 4.

${ }_{63}$ The Dominion, 25 March 1937, p. 13.

${ }^{64}$ Otago Daily Times, 3 April 1937, p. 5.
} 
experience in the geothermal region, the multitude of hunting options, the beauty of the landscape and just how thoroughly decent and British New Zealanders were. Such published accounts promoted New Zealand as a good location to visit and even to settle in. However, these books often included the players' experiences in other parts of the cricketing world, and New Zealand was certainly not exclusive in receiving praise and admiration.

Sports tour writing is part of the greater canon of popular travel writing that began in the Victorian age as an elitist hobby. As shipping routes became faster, the middle class more affluent, a broader range of people were able to access the world beyond their town or city of origin. Tourism and the subsequent writing about the experience were the outcome that was consumed but curious future tourists and those who could not travel. ${ }^{65}$ There was clearly a market for cricket travel writing, if the number of biographical-travel titles written by players is a guide. In a sense these cricketers extended themselves beyond players to become explorers and interpreters in the eye of the reader, they became travellers and cricket players.

Pelham Warner wrote an account of his experiences in New Zealand in 1902-03 Cricket Across the Seas. ${ }^{66}$ Thirty years later he managed the MCC side that visited in 1932-33 and his experiences were briefly recorded in his famous book, Cricket Between the Wars. ${ }^{67}$ In both books Warner combines two of his obvious passions, cricket and travel. Warner, displaying diplomatic skills which would have been useful a few months earlier during the Bodyline tour, exchange platitudes with an unnamed Maori chief while in Rotorua:

We spent a few days at Rotorua in the Maori country, and there we were welcomed by the Chief. Through an interpreter he made a most eloquent speech of welcome, beginning with "Distinguished strangers from beyond the far horizon" and continuing in a manner which even a Churchill could scarcely have surpassed. He referred to King George V in terms of great loyalty and to "that country beyond the seas of which they were so proud to be a part, if a distant part." I had to reply to this fine oratory and did not feel at all happy

\footnotetext{
${ }^{65}$ Barbara Brother \& Julia M. Gergits, (ed.), "British Travel Writers, 1910-1939', Dictionary of Literary

Biography, Volume One Hundred Ninety-Five, Detroit, 1998, p. XV.

${ }^{66}$ Sir Pelham Warner, Cricket Across the Seas, London, 1903.

${ }^{67}$ Sir Pelham Warner, Cricket Between Two Wars, London, 1942 (1946).
} 
about it. I felt that I could not possibly open in conventional style; but just before the end of the Chief's oration I bethought me of King Solomon's Mines. So I opened with "Great Chief, Incomparable One," which went down well, as did a reference to the prowess of the Maoris at Rugby football, mentioning George Nepia, the famous full-back. I was told afterwards that I could not have made a happier remark, "as it was still the ambition of every Maori wife to have a Rugby-playing son.” The Maoris are born orators and are blessed with the most attractive and fascinating speaking voices. The New Zealanders are as charming a people as their island is beautiful. ${ }^{68}$

Warner's paragraph provides a picture of a warm and reciprocal engagement where commonality is found through sport, though not cricket in this case. To the reader, the Maori are portrayed as exotic and enthusiastic members of the British realm. Warner's writing also suggests a real sense of adventure and exchange for the reader out of what was probably a more formal encounter. Warner and other writers of sports travel accounts were raised on the popular adventures books like Rider Haggard's King Solomon's Mines which possibly coloured their stories with a nineteenth century notion of adventure.

The captain of the MCC 1935-36 tour, E. R. T. Holmes, also reflected on his experiences with Maori in Rotorua, further confirming the secondary place for cricket for the tourists when offered the exotic landscape and exciting cultural experiences:

[In Rotorua], my memory of the game is almost nil, my whole attention having been taken up with the marvels of this wonderful place, which I felt, might disappear in smoke at any moment, so great appeared to be the pent-up force which lurked only just below the ground.

On the first evening, we went to a concert performed by Maoris, which seemed to have been produced by Rangi, the famous guide, who was later to show us all the sights. We were intrigued by the "Poi" dances and captivated when they all sang, "Now is the Hour", [with] the accompaniment of guitars. It was impressive and very moving. ${ }^{69}$

Rangi also guided the MCC team round the geysers and mud pools and invited the team to visit her house. Holmes noted that 'we saw, first hand, how cultured and

\footnotetext{
${ }^{68}$ Ibid. p. 144.

${ }^{69}$ E. R. T. Holmes, Flannelled Foolishness, London, 1957, p. 138.
} 
polished are these very attractive people, who we had little previous opportunity of meeting. ${ }^{70}$ Rangi, whose full name was Rangitiaria Dennan, had a long and illustrious career as a guide, and interestingly the first-ever tour party she guided was the MCC team that visited in $1922 .^{71}$ The Maori guides had been an essential aspect of the Hot Lakes District since the 1870s, but became more established at the beginning of the twentieth century when guiding became a major activity amongst the women of the Tuhourangi and Ngati Wahiao. ${ }^{72}$

The interwar years are an interesting period for Maori ethnographic exhibitions and tourism. Margaret McClure in The Wonder Country alludes to the decline and dilapidation of Maori culture and art in places like Whakarewarewa and Ohinemutu but also of the regeneration from the 1920s onwards due to the efforts of Apirana Ngata. $^{73}$ Conal McCarthy, when principally describing the museum exhibition of Maori culture during this period, discusses the very different ideas of Maori and Pakeha regarding representations of Maori culture between the wars. The exhibition and display of Maori culture as envisioned by Ngata and Peter Buck is that of a living culture; it was intended to help in the regeneration of Maori cultural life. Concurrent Pakeha expectations of Maori cultural presentation is one of exhibiting the past as a peaceful and jointly beneficial story, while also displaying examples of western manners and mores amongst Maori that represent their gradual assimilation. $^{74}$

Along with the hot pools and associated Maori cultural exchanges, hunting and fishing were major attractions, advertising New Zealand's varied tourist avenues and providing an experience in line with that expected by the idealised amateur sportsman of independent means. In the first years of the twentieth century, Thomas Donne, the first Superintendent of the Department of Tourism and Health Resorts encouraged the renowned English game hunter, St George Littledale to visit New Zealand. Littledale assessed the mountains of New Zealand as a fine setting for deer

\footnotetext{
${ }^{70}$ Ibid. p. 139.

${ }^{71}$ Rangitiaria Dennan with Annabell Ross, Guide Rangi of Rotorua, Christchurch, 1968, p. 75; see Sandra Coney, Standing in the Sunshine, pp. 216-217 for more about tourist guides in the Hot Lakes District; Biography of Rangitiaria Dennan. Cushla Parekowhai. 'Dennan, Rangitiaria - Biography', DNZB, Te Ara, http://www.TeAra.govt.nz/en/biographies/4d12/1; updated 1 Sep 2010.

${ }_{72}$ Sandra Coney, pp. 216-217.

${ }^{73}$ M. McClure, The Wonder Country, pp. 109-110.

${ }^{74}$ Conal McCarthy, Exhibiting Maori, Oxford, 2007, pp. 61-66, see also Belich, Paradise Reforged.
} 
and goats. ${ }^{75}$ As E. R. T. Holmes discovered hunting in New Zealand does not carry the same prestige and glory as a tiger hunt in India, but rather fulfils a basic necessity of country living. This was certainly the case during a hunt near Timaru:

To this day, I do not know who was in charge of that party, but it did not seem to matter, not at that stage, at any rate. By some mutual agreement, for no signal was given, as far as I could see, we started to move forward, and very soon a hare started up in front of me. I fired and killed it, then went forward, picked it up and held it aloft, wondering who was going to carry it, but nobody paid any attention. Determined that I was not going to be saddled with the thing myself if I could possibly avoid it, I shouted to my neighbour, "What shall I do with this?" "Oh just leave it," he replied, whereupon I realised that we were not shooting "for the pot" but merely to keep down the vermin. ${ }^{76}$

Holmes, though, clearly enjoyed his day, which had been his first full day without cricket, for he noted: 'I regarded [today] as, perhaps, the happiest day which we had experienced since we started the tour. ${ }^{77}$

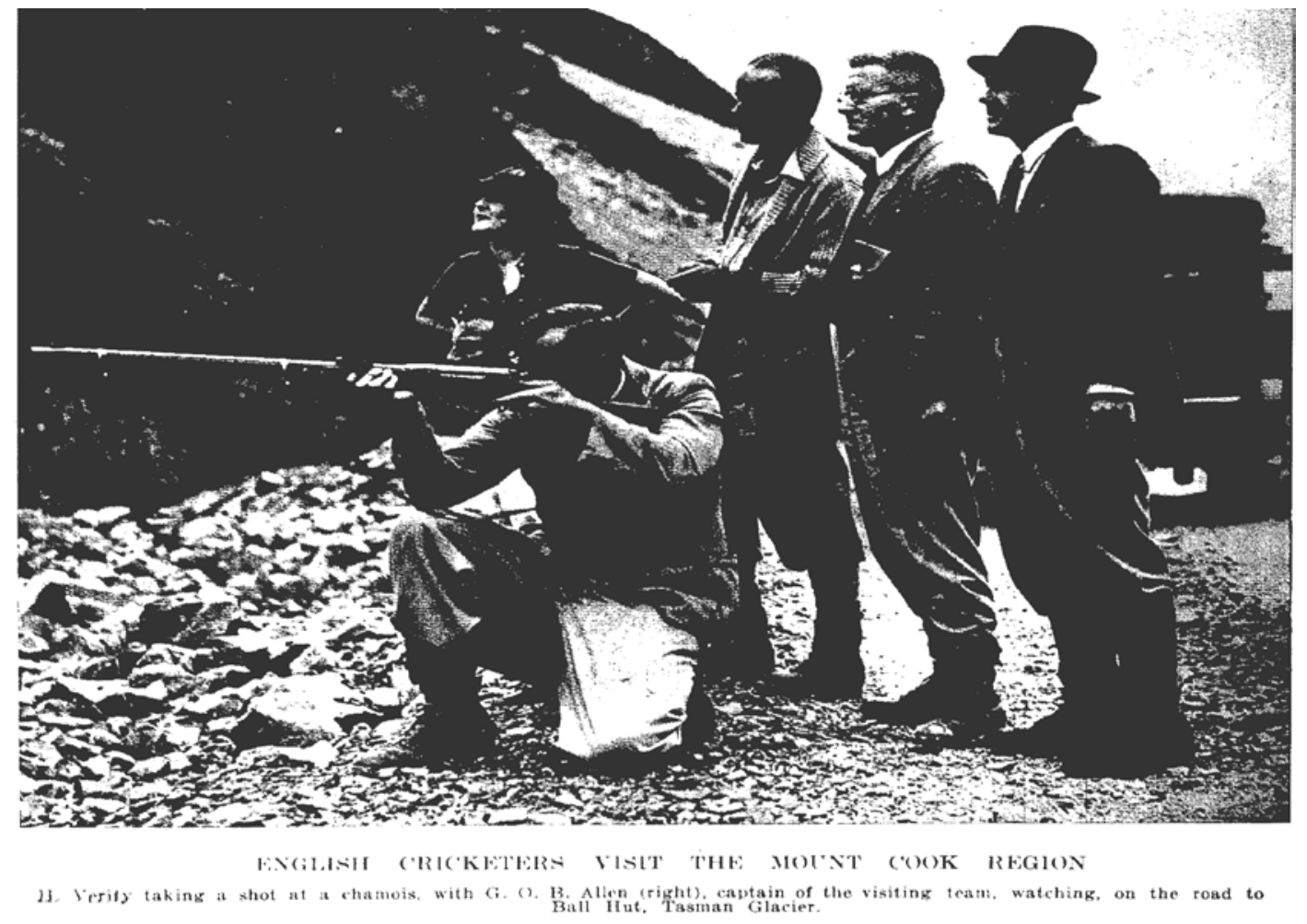

The Weekly News, 31 Mar 1937, p 57 reproduced courtesy of the Alexander Turnbull Library

\footnotetext{
${ }^{75}$ Margaret McClure, The Wonder Country, p. 52.

${ }^{76}$ E. R. T. Holmes, Flannelled Foolishness, pp. 127-128.

${ }^{77}$ Ibid.
} 
Perhaps the English cricketer who gained the maximum benefit from his time in New Zealand in the 1930s was Walter Hammond. Hammond scored a then world record score of 336 not out against New Zealand at Auckland in 1933 and toured again with the MCC side of 1936-37. Apart from enjoying the hot pools and scenery he clearly loved the fishing. Instead of playing a tour match in 1937 he took up an offer to go sword-fishing in the Bay of Islands. He recounts this venture in his memoir, Cricket My Destiny, 'sailing the blue bays off New Zealand with the glorious mountains and glaciers in the distance, and the prospect of fun and excitement with the big fish, is a pastime of which I should never tire. ${ }^{178}$

Hammond's enthusiasm for fishing was raised after the war when the NZCC were looking to organise the next MCC tour. The letter between Endell Wanklyn, representing the NZCC and J. W. Heenan of the Department of Internal Affairs in 1946, further confirms the aspirations of cricketers touring New Zealand:

As far as can be seen at present the visit of the MCC side looks a certainty. We had a very pleasant letter from Howard, who seems to be as co-operative as possible to one of his disposition. Hammond, I know, is determined to get here, which will be a great help. Between ourselves I think his main object is some deep sea fishing, which you may remember he had last time, but still as long as they get here it is the main thing. If they do it will probably mean some pretty fast work by your Tourist Department to get all the fishing arrangement put in order for short notice. Last time he went to Mayor Island, and this time will probably want the Bay of Islands. ${ }^{79}$

Hammond did indeed return to New Zealand (in 1947) and played the last test match of his illustrious career for England at Christchurch. He scored 79. Hammond was given three cheers from the New Zealand players and the umpires and received applause from the appreciative crowd. ${ }^{80}$ Hammond was a fascinating character and one very much in tune with the contradictory nature of cricket in the 1930s. He was a professional but changed his status to amateur partly through taking a directorship of a tyre company in 1938. ${ }^{81}$ For Richard Holt, Hammond's career 'illustrates the

\footnotetext{
${ }^{78}$ Walter Hammond, Cricket My Destiny, London, 1946, p. 101.

${ }^{79}$ Endell Wanklyn to J. W. Heenan, 7 October 1946, re: cricket and racing, MS-Papers-1132-247, Alexander Turnbull Library, Wellington.

${ }^{80}$ Match report in D. O. Neely, et. al., Men in White, pp. 175-176.

${ }^{81}$ Richard Holt, Sport and the British, Oxford, 1989, p. 291.
} 
expanding commercial possibilities for famous sportsmen outside the field of play. Taking money for playing still disqualifies a man for the highest honours in the amateur system, but profit from sporting fame indirectly through directorship did not. ${ }^{82}$ His fame helped him to secure exciting and fulfilling opportunities off the field while on tour for the MCC.

What is universal across the accounts of the cricketers on tours in the 1930s is the enthusiastic reception and generosity shown towards them during their visits. Clearly, because they were cricketers - and in the case of the MCC, representatives of the most prestigious team in the world - they were given more than an average tourist experience. They were treated well because it reflected well on New Zealand and on the Dominion's place in Empire. The great English batsman Herbert Sutcliffe visited New Zealand with the MCC 1932-33 side and reflected later in For England and Yorkshire:

A wonderful little country is New Zealand, with its hot lakes, spouting geysers, its west coast Fjords in the South Island which rival those of Norway in their enchanting beauty, its magnificent snow-capped mountain-ridges, and above everything else, its glorious loyalty to the Motherland. You cannot find a better British subject than the Briton who is a New Zealander. I found the country something of a paradise. $^{83}$

These cricketers were often coming to the end of their careers as players and administrators when they wrote these accounts and therefore establishing themselves as, more than just sportsmen, but also well-travelled and experienced men of the world. There is a personal prestige to the writing, clearly, but also an establishing of popular ideas about places within the Empire and beyond. As already seen with Hammond, New Zealand administrators and officials were keen to provide the best possible experience, which would then be presumably reported back home. The image of New Zealand as an idyllic, less complicated and less populated version of Britain, certainly seems to have worked according to a Gallup poll in Britain in 1948 which Belich uses to argue his 'Better Britain’ case. The poll suggested that of the 48 percent of people who wanted to emigrate, eight percent of those wished to move

\footnotetext{
${ }^{82}$ Ibid.

${ }^{83}$ Herbert Sutcliffe, For England and Yorkshire, London, 1935, p. 159.
} 
to New Zealand - therefore the attractiveness of New Zealand per head of population was four times greater than Australia, over twelve times greater than Canada and one-hundred and fifty times greater than America. ${ }^{84}$ Part of this postwar popularity was down to the impression of New Zealand as a mixture of exotic but also idealised England as perpetuated in the books written by travelling cricketers.

This MCC side's brief tour of New Zealand came after an unsuccessful attempt at wresting the Ashes from Australia. The tour came at the end of a very long season for the MCC players and they were clearly concerned with relaxation and holidaying as much as sport. The tour produced standard but unexciting victories for the MCC in the tour games and a dramatic last gasp draw in the only test. It also brought a surprise financial loss, which further endangered the fragile financial position of the NZCC. As with many sides visiting New Zealand, the lack of quality opposition and the low-key nature of the cricket meant the visiting side was often more interested in the natural environment, as well as the cultural and social experiences on offer in New Zealand. The players' interest in New Zealand's landscape, indigenous culture, hunting opportunities and social events were recorded in various journals and sports books written at that time. The positive non-cricket experiences helped provide the cultural bond that was lacking at times in the cricket itself.

\footnotetext{
${ }^{84}$ James Belich, Paradise Reforged, p. 83.
} 


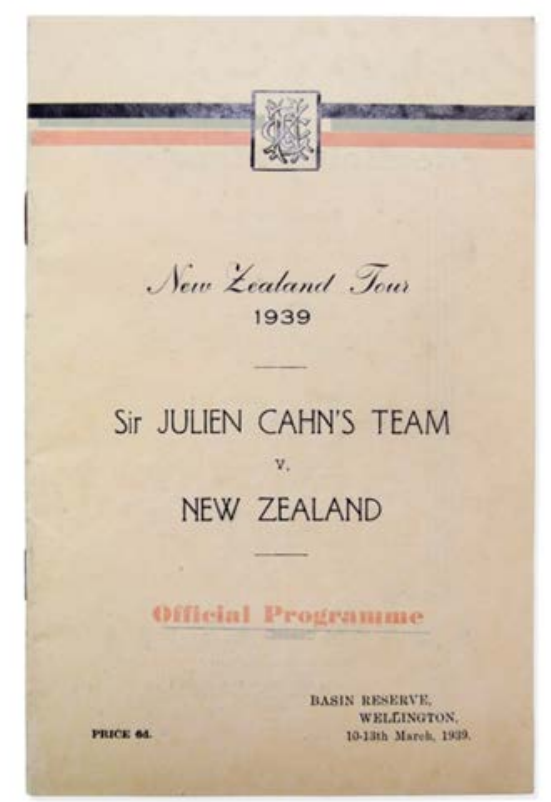

Sir Julien Cahn's Team v. New Zealand, Official Programme

Printed Ephemera Collection, Courtesy of New Zealand Cricket Museum

\section{Sir Julien Cahn XI}

The last cricket team to come to New Zealand in the 1930s was a private tour in 1939 captained and financed by the eccentric millionaire, Julien Cahn. The tour was instigated by Cahn and former New Zealand international, Stewie Dempster. ${ }^{85}$ Cahn was enthused about visiting New Zealand as one of the few cricket playing countries he had not toured. According to Dempster, probably only half jokingly, Cahn's aim was to claim revenge for the defeat New Zealand had inflicted on his XI during New Zealand's tour of England in $1937 .^{86}$

The tour occurred when the threat of war was certainly in the news and the task of preparing for it was underway. The anxiety and threat in Europe was also felt in New Zealand. During the Cahn tour, The Press published a map of Europe that showed the planned conquests by Germany, including Great Britain. The map was stated to have been found in the offices of Herr Henlein, the Sudeten German leader

\footnotetext{
${ }^{85}$ Dempster had been persuaded to leave New Zealand cricket and play for the Cahn XI in England earlier in the 1930s.

${ }^{86}$ New Zealand Truth, 1 February 1939, p. 5.
} 
before the Munich agreement was signed, and evidence of Nazi ambition. ${ }^{87}$ Such clear threats to Britain were responded to by a call to arms, and expressions of unity within the Empire. Sir Thomas Inskip, The Secretary of State for Dominion Affairs, speaking to the New Zealand Society in London, announced at the time of the Cahn tour that:

New Zealand is the furthest from the United Kingdom of all the Dominions, but it lies very close to the heart of us all in the country... When we speak of New Zealand we feel we are speaking of intimate members of our own family. There is something about the Dominion which makes us feel instinctively as much at home as we hope that visitors and relations feel when they come to this country. ${ }^{88}$

The Cahn tour came at a time of threat to British and thus New Zealand interests and was received well by the New Zealand public. Cahn was a curious and uncomfortable figure, whose approach and lack of cricketing ability may not have received the same response from the New Zealand public had the times been different. The tour that unfolded was one of competitive but relaxed matches played in a spirit of conviviality. Even so, the tour also was demonstrative of the capitalistic forces that were edging into the game.

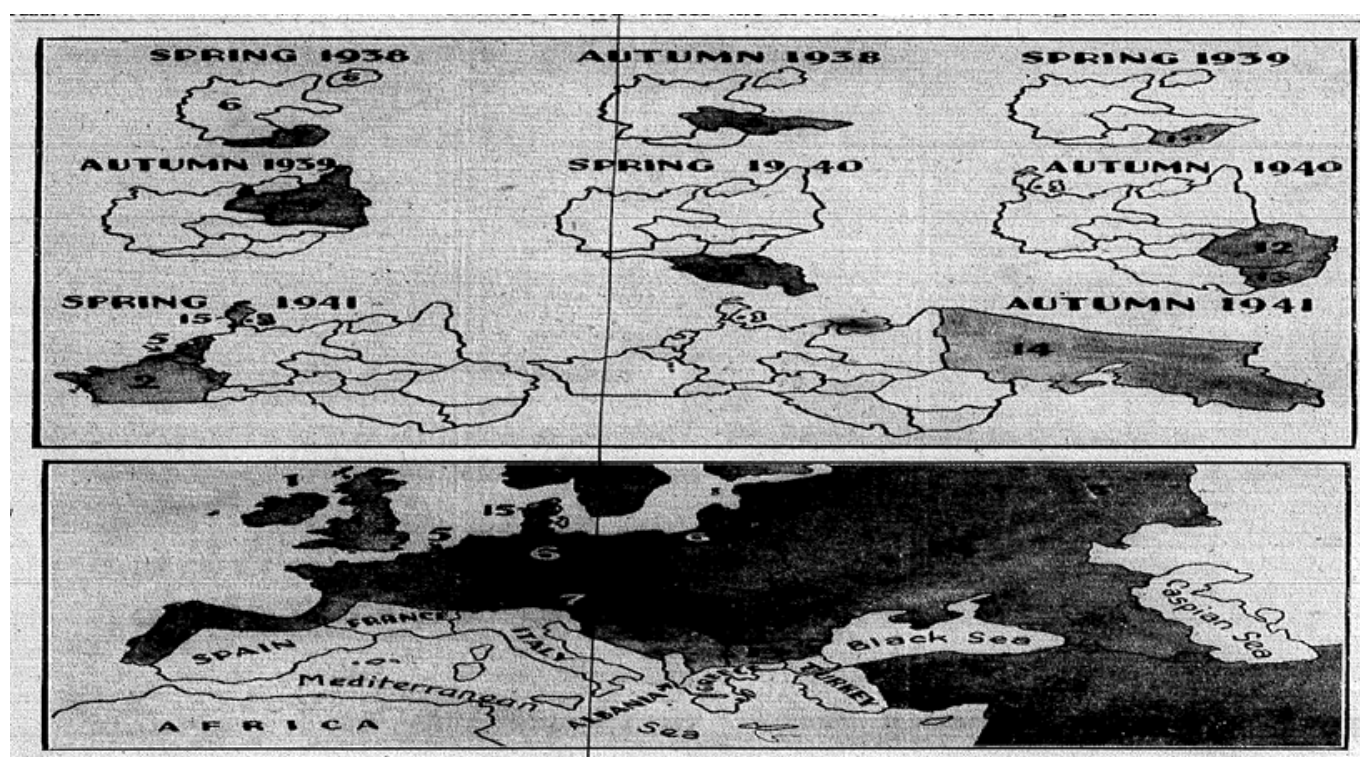

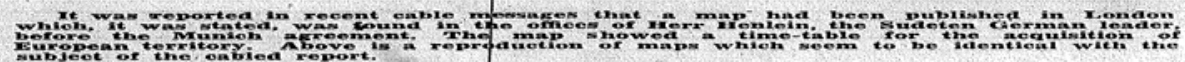

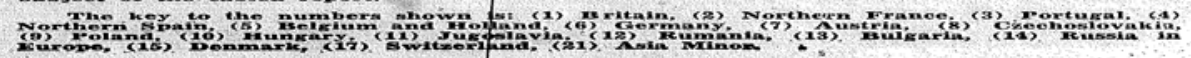

'Timetable of Conquest', The Press 24 March 1939, p 13, Image reproduced courtesy of the Alexander Turnbull Library.

\footnotetext{
${ }^{87}$ The Press, 24 March 1939, p. 13.

${ }^{88}$ The Press, 18 March 1939, p. 10.
} 
Cahn's tour possessed many of the characteristics of early tours to New Zealand, such as the Lord Hawke XI of 1902-03, in that the tour was privately funded, proposed as an educative experience for the host teams. The players were a selection of stars and journeymen. At the same time the Cahn XI exemplified the changing nature of cricket: the team was multi-national, and played in large part to further the ambitions of Cahn himself. Christopher Martin-Jenkins sees Cahn as 'part of a long line of private sponsors stretching from the Duke of Richmond in the eighteenth Century to Kerry Packer in the twentieth, who had in common a role as benefactors to contemporary players of talent. ${ }^{89}$ Cahn's visit to New Zealand exemplified the two faces of cricket; on the one hand the traditional and deeply cherished altruistic and convivial nature of the sport, and on the other, a ruthlessness sporting system where financial opportunities could override national (or other) loyalties and considerations.

The tour consisted of ten games and pitted the Cahn XI against a curious and diverse range of opponents. There were two games against youth selections - a Combined Secondary School match in Auckland and a game against South Island Colleges held at Waitaki High School. These matches were considered important because of the emphasis Cahn placed on developing youth interest in cricket, even if the match-up between his team and the school teams was decidedly one-sided. A further deviation from the standard tour schedule was for the Cahn team to play an amalgamated team selected from the minor associations. This was in contrast to the usual tour schedule that included a large number of one-sided contests against regional teams which had often proved frustrating and financially fraught propositions. The Cahn side would also play the major provinces, including Otago, who had missed out on several tours in the 1930s, and an unofficial 'test' against a New Zealand selection at Wellington. The tour was approximately five weeks long, giving the visitors ample chance to see the country. The touring party included Lady Cahn, Cahn's brother-in-law and a personal maid. ${ }^{90}$ Like all tours to New Zealand in what must have been one of the wettest decades on record, the tour was blighted by bad weather. The relaxed, though competitive, expectations of the tour were summed up by Wellington player J. R. Lamason in the New Zealand Free Lance:

\footnotetext{
${ }^{89}$ Martin-Jenkin's quote is on the cover sleeve of Miranda Rijks, The Eccentric Entrepreneur, Stroud, 2008.

${ }^{90}$ Miranda Rijks, The Eccentric Entrepreneur, p. 179.
} 
It is true that the visitors are not undertaking a very strenuous tour and many of the games are of a purely social nature, but the match against the elect of New Zealand is going to be regarded with all due seriousness. ${ }^{91}$

The schedule apart, this tour to New Zealand is fascinating because of the curious character of Julien Cahn. He was a British-born Jewish millionaire with a taste for magic, fox hunting and most importantly, cricket. Cahn made his fortune through a mass-market hire-purchase furniture business which had warehouses across the whole of England. When not running his business empire or developing his mansion, Standford Hall, at Loughborough, he engaged his passion for cricket to the extent of owning his own ground, organising tours and maintaining a stable of high class cricketers. ${ }^{92}$ Cahn, for all his wealth, was an outsider, and clearly used sports and the funding of charitable foundations to further his position in society. Despite acquiring a knighthood, he was never accepted into the upper-class aristocratic echelons to which he aspired. Jack Williams suggests that Cahn's heritage was possibly a factor in his non-selection for membership of the MCC. ${ }^{93}$ There were very few openly Jewish cricketers recorded in the interwar years, with Cahn the obvious exception. The dislike of Cahn by the MCC certainly outlasted his own lifetime. Miranda Rijks, in her biography of her grandfather, includes a letter written by Charles Lyttleton in 1954 when he was President of the MCC, to Harry Altham the MCC treasurer, regarding his concerns about membership numbers and the need to increase the entrance fees:

it is so important for us not to put membership beyond the means of the very people we want as members - the young, the 'professional classes' and the Service members. If we apply too stringent an economic sanction, we will find the place full of Sir Julien Cahns. ${ }^{94}$

Cahn's genuine interest in cricket and the satisfaction he gained from it went further than owning his own cricket team. He was heavily involved in assuring the financial security of both the Nottinghamshire and Leicestershire County sides. He employed their players in his stores, was at times President of the Nottingham County Club as

\footnotetext{
${ }^{91}$ New Zealand Free Lance, 1 March 1939, p. 59. Lamason also played for New Zealand but was not selected for a Test match.

${ }_{92}$ Miranda Rijks, The Eccentric Entrepreneur.

93 Jack Williams, Cricket and Race, pp. 41-43.

${ }^{94}$ Miranda Rijks, The Eccentric Entrepreneur, p. 97.
} 
well as representing, for some years, Leicestershire on the Advisory County Cricket Committee. ${ }^{95}$ He was also a keen player, even in New Zealand when aged 57, though his passion certainly did not transfer into any ability in the game. The Cricketer magazine in September 1997 described Cahn as: 'At once the most prolific patron of cricket between the wars and comfortably the worst ever first-class cricketer. ${ }^{96}$ He was a poor batsman and weak bowler with a lob action. He famously experimented with inflatable pads, which further added to the mirth surrounding his batting. Even so, such was his financial position and his generosity to players that he would appear to have generally been offered a 'gimme' at the start of an innings. Stories abound of umpires turning down obvious LBW shouts when he was at the crease, in fear of the consequences of angering Cahn and jeopardising any future benevolence.

The match accounts of the tour of New Zealand give a glimpse of Cahn's ability - or lack thereof - with both bat and ball. In the game versus Auckland, with the match winding down, Cahn bowled what was described as a 'queer mixture of full tosses, longhops and an occasional ball that, much to the joy of the crowd, hopped several times.' The temptation proved too much for the Auckland batsman Weir who 'swung cheerfully at one very long hop to try and get his century and landed the ball into Watt's hands at deep mid-on. It is not always a good ball that gets a wicket, and incidentally it was the only one that Sir Julien got on the whole tour. ${ }^{97}$

Cahn may have been a poor cricketer but the teams he acquired were of first-class standard and not exclusively English. The team that travelled to New Zealand included four Australians who had experience in Australia's domestic competition, the Sheffield Shield, before 'the greater possibilities of English cricket called them Home. ${ }^{98}$ The team also included New Zealand's best cricketer of the 1930s, Stewie Dempster, who in his ten test matches for his country averaged a world class 65.72. ${ }^{99}$ His obvious talent made him a target for Cahn, who wanted high quality cricketers for his own personal team, but also a captain for the struggling county of

\footnotetext{
95 Duncan Hamilton, Harold Larwood, p. 191, Benny Green (ed.), Wisden Anthology 1940-1963, p. 79.

${ }^{96}$ Cricketer quoted in Rijks, The Eccentric Entrepreneur, p. 21.

${ }^{97}$ Auckland Star, 21 March 1939, p. 15.

98 Otago Daily Times, 27 February 1939, p. 12.

99 ' New Zealand/Players/Stewie Dempster', Cricinfo; available from

http://www.cricinfo.com/newzealand/content/player/36827.html; accessed 6 October 2010.
} 
Leicestershire. Clearly Dempster needed to earn a living but it was still not the done thing for a captain of an English side to also be a professional cricketer. Therefore, in order to get around the thorny issue of professionalism, Cahn made Dempster the manager of one of his furniture stores, while he was waiting to obtain a residential qualification. $^{100}$

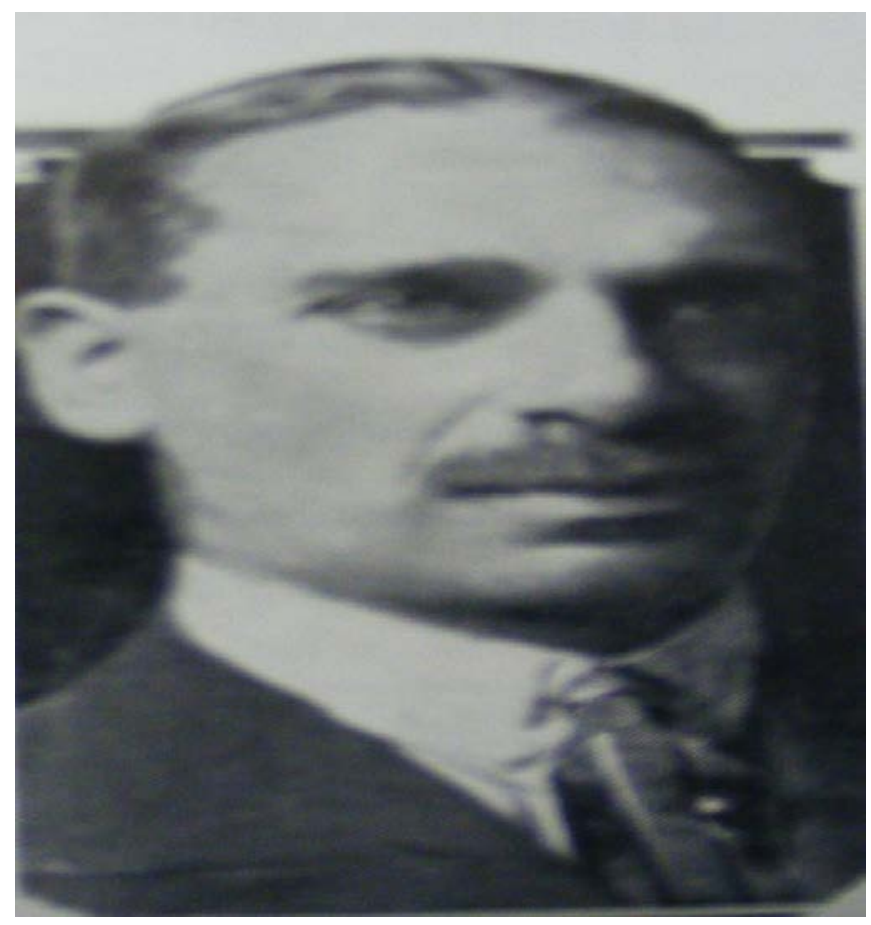

Julien Cahn. Image courtesy of the New Zealand Cricket Museum

Dempster's arrival back home in New Zealand was greeted with interest because of his obvious ability and ties to the Dominion, though it was noted that he appeared a more conservative batsman during his time in England, and not the 'dasher' that appealed to New Zealand's cricketing sensibilities. ${ }^{101}$ When asked to talk about the team that Cahn brought to New Zealand he described them as 'cosmopolitan' because of the Australasian flavour that marked the side from the teams of Englishborn players that generally visited. The make-up was not unusual for a Cahn selection as he was, seemingly, not fussy regarding the birth place of his players, focussing just on their ability. In the 1930s, when his team was considered at its strongest, it included three South Africans, four Australians and two New Zealanders, including Dempster. ${ }^{102}$ Cahn had agents, including former Australian

\footnotetext{
${ }^{100}$ Jack Williams, Cricket \& England, p 119. Williams has sourced material from D. Lambert, The History of Leicestershire County Cricket Club, London, Christopher Helm, 1992, p. 120.

${ }^{101}$ Otago Daily Times, 9 March 1939, p. 4.

${ }^{102}$ Miranda Rijks, The Eccentric Entrepreneur, p. 97.
} 
opening bowler Alan Fairfax, as scouts for players. The normal technique to lure cricketers was simply to offer them a deal that they could not turn down. This included paying for a player's accommodation, living expenses and cricket-related costs, plus the obvious exciting attraction of international travel in first-class conditions. $^{103}$

The mixture of sporting tradition and aggressive commercial nous in Cahn's personality made him a curious figure, but also a representative of the greater internal ructions happening within cricket itself during the decade. Money had always played a part in cricket despite the holier-than-thou posturing of amateurs who, with grand hypocrisy, often in fact earned more from the game than the hardworking professionals. In the 1930s, the financial brinkmanship played by the Australians after the Bodyline series, and the aggressive acquisition of outstanding players by Cahn himself, hinted at the greater financial stakes that were now part of cricket. The irony is that Cahn, the millionaire product of modernity, who was building his fortune on cheaply made furniture, really just longed to be part of an old order that still held sway. The problem for Cahn was that, though he was desperately keen to be seen as part of the aristocracy, he also liked to show off his wealth in rather ostentatious and vulgar ways. This made him appear déclassé to the establishment figures who were probably already put off by the fact that he was Jewish. Cahn never gave up though and saw the acquiring of an all-conquering cricket team as a stepping-stone to greater position and esteem.

At the end of the tour, Cahn's secured the services of the highly skilled Auckland and New Zealand all-rounder Giff Vivian. Vivian had been a semi-regular in the New Zealand test side since 1931, the highlights of his career being a Test century against South Africa, and scoring a 1000 runs in both the 1931 and 1937 tours of England. The press reports appear to repeat themselves in congratulating Vivian in securing a position in Cahn's furniture business and cricket team. ${ }^{104}$ Vivian's decision to abandon New Zealand cricket for Cahn's stable is understandable because of the short duration of sporting careers and limited financial avenues that were open to him through the game in New Zealand. His loss to New Zealand

\footnotetext{
103 Ibid. pp. 177-178.

${ }^{104}$ The Dominion, 23 March 1939, p. 11.
} 
cricket was however sobering for the local game, then fighting for credibility on the international stage. The New Zealand Herald reflectively added:

The loss of Vivian will not only be felt by Auckland, but also by New Zealand, as the Dominion team next year has to prepare for a visit from the Australian eleven, captained by Don Bradman. A left-hand batsman who plays very stylishly, Vivian is a wily spin bowler, whose place will be hard to fill. He is also a capable and reliable fieldsman. ${ }^{105}$

The loss of Vivian was something the NZCC appeared powerless to stop. Vivan had signed an agreement with the NZCC not to leave New Zealand for the space of two years after the conclusion of the 1937 tour of England. ${ }^{106}$ In the past, players had been censured for breaking agreements with the NZCC, but apart from restricting players' options on return from England, there was little they could do if a player wished to pursue a more lucrative sporting career overseas. After discussion it was agreed to write a strongly worded letter to Vivian stating that he should have sought permission before quitting New Zealand cricket. But to Cahn, regarding the contracting of Vivian, they cabled simply, 'no objection your engagement Vivian'. ${ }^{107}$ One assumes that the NZCC did not wish to offend this powerful figure or risk damaging future relations, particularly as the New Zealand side had played tour matches against the Cahn XI on past visits to England.

Cahn's wealth and past patronage made him not only a magnetic figure but also a difficult person to deal with. The NZCC minutes reveal a great deal of acquiescence on the part of the Council because of the realisation that he was calling the shots. An example of his will being acceded to can be seen in the decision to play in Wanganui rather than New Plymouth. The Council preferred the choice of New Plymouth because of their understanding of the relative strength of regional cricket. The Council offered the blunt assessment, 'Wanganui bad cricket centre and bad wicket'. ${ }^{108}$ Cahn after some confusion refused to change. Finally the Council

\footnotetext{
${ }^{105}$ New Zealand Herald, 23 March 1939, p. 15.

${ }^{106}$ NZCC, Management Committee Minutes, 27 March 1939, New Zealand Cricket, Christchurch, In the minutes Cahn's initial cable to NZCC suggests that it was Vivian who instigated the deal. 'Vivian has approached me for position England am willing engage if you have no objection please reply S S Niagra Cahn.' This is interesting as this was not how Cahn generally secured prospective players. Possibly this cable was Cahn attempting to deflect potential criticism of his acquirement of Vivian. D. Neely et. al. Men in White, states 'Giff Vivian had accepted a position in Cahn's business empire', p. 172.

107 Ibid.

${ }^{108}$ NZCC, Management Committee Minutes, 25 November 1938, New Zealand Cricket, Christchurch.
} 
acquiesced and the game was played in Wanganui. In the match the local side were skittled for 121 and the Cahn XI rattled up 291-3 in a drawn match. ${ }^{109}$

Another curious decision made by Cahn was that the tour matches be 12 aside games, but with only eleven fieldsmen. This was justified on the grounds that the tour was of limited length. Playing twelve men reduced the number of touring players having to stand down for a match. ${ }^{110}$ In truth, this also meant Cahn himself could be replaced in the field when he wished to have a rest. The choice of making these games 12 aside meant that only the 'Test' match against a New Zealand selection, which was played as an 11 aside match, was granted first class status by the MCC.

From an economic point of view, the tour was initially seen as a guaranteed financial success because of Cahn's benevolence, and public interest in his team. Poor weather, the eventually less charitable nature of Cahn's tour proposal, and perhaps some of the game scheduling meant the visit did not provide the boon so desired by New Zealand cricket. Instead, only a very small profit was made. Whilst Cahn's initial tour proposal was very attractive - he was offering to pay all his party's travel and hotel expenses and did not claim any share of the gate takings ${ }^{111}$ - he later advised the NZCC that he desired the Council to pay the travel costs in New Zealand, which led to this cabled reply from the Council:

Estimated transit charges for sixteen[,] two hundred fifty pounds council would reimburse Cahn but in view our financial position any charges reduce attractiveness original offer. $^{112}$

The changes were made, but considering Cahn was known for his incredible wealth and generosity the renegotiation of the deal after the initial proposal appears surprisingly penny-pinching. Cahn did, however, gift $£ 100$ to the NZCC (reported as $£ 125$ in some media sources), to help cover the loss of earnings from the match against New Zealand, which was severely affected by the weather. The sum was

\footnotetext{
109 'Wanganui v Sir J. Cahn XI', Cricket Archive; available from http://cricketarchive.com/Archive/Scorecards/136/136296.html; accessed 9 November 2010.

${ }^{110}$ New Zealand Herald, 17 March 1939, p. 13.

111 NZCC, Management Committee Minutes, 25 February 1938, New Zealand Cricket, Christchurch.

112 NZCC, Management Committee Minutes, 2 May 1938, New Zealand Cricket, Christchurch.
} 
gratefully received by the NZCC, but this generosity was tempered by the loss of Giff Vivian to New Zealand cricket.

The awkward dealings with the NZCC, and the contracting of Giff Vivian to his team, did not impact on Julien Cahn's reception in New Zealand, nor that of his team during the tour. The Auckland Star referred to him as 'that great sportsman'113 and N. B. Palethorpe noted, rather breathlessly, his views on the tourists:

Sir Julien Cahn's team, now touring New Zealand, is proving as popular among hosts and hostesses in the Dominion as it is among the cricket fans. On the field these men are immaculate. They go about their cricket in the same precise, capable manner in which the doctor goes through his ward at the hospital. In flannels they are gods among men, but off the field these gods are very likeable fellows, glad to be seeing the country and meeting the people from 'down under'. ${ }^{114}$

In part, the excitement was due to the glamour of having such a famous businessman and sporting philanthropist with his merry band of travelling cricketers in the country. Newspapers gushed and marvelled at his perceived wealth and benevolence, while Cahn himself talked about the goodwill and advancement in cricket that the tour would hopefully provide. Dempster, in advance of the tour, proclaimed that Cahn 'would be a mighty asset to cricket in our Dominion.'115 Although his XI was effectively a hired team, it nevertheless contained players who would be selected for England, most notably Joseph Hardstaff, who had toured New Zealand with the MCC in 1935-36. Because of this, the tour could carry the distinction of being an educative tour from 'home' like the previous MCC visits.

When the Cahn XI visited Dunedin they were met by the mayor, Andrew Allen, who, while lamenting the state of cricket in the region, nevertheless saw in the exchange all its advantages, much as if the tour was by the MCC:

Cricket in Dunedin has never received the public support we should like, but it has always been fostered by a loyal band of enthusiasts who have not spared themselves in the interest in the game. I hope we will be able to give your team a good game, so that we may extend you to the point of showing us the finer points of cricket. Nevertheless, it is the game that

\footnotetext{
${ }_{113}$ Auckland Star, 18 March 1939, p. 10.

${ }^{114}$ New Zealand Observer, 2 March 1939, p. 7.

${ }^{115}$ New Zealand Truth, 1 February 1939, p. 5.
} 
counts and it does not matter who wins. I sincerely hope that you will enjoy your stay in Dunedin. ${ }^{116}$

Cahn's response, while complimentary, outlines his competitive edge and the tenuous financial position of New Zealand cricket:

In Nottingham, where I live the Lord Mayor is always a vicepresident of the cricket club. He usually knows nothing about the game however, so that it is rather refreshing to find that Dunedin has a Mayor who is also keenly interested in cricket. I am afraid I cannot agree with you that it does not matter who wins, especially as the game seems to need some financial assistance in New Zealand because if we are beaten by Otago it is likely that it will seriously affect the gates later on. ${ }^{117}$

The tour itself produced acceptable results for the tourists. Though they did not dominate their New Zealand opponents, they left unbeaten. The tour record of five draws and five wins reflects not only the short nature of the games and the poor weather, but also the strength of the regional sides in comparison to the Cahn XI. Sadly, the one unofficial test match was ruined by the weather. New Zealand managed 170-5 and the Cahn team in response reached 163-7 before time elapsed. ${ }^{118}$ The relative success of Canterbury who held the Cahn XI to a deserved draw and the strong performance by New Zealand left cricket supporters and administrators excited about the prospects going into the next series. An Australian team, including Don Bradman, was scheduled to arrive in the 1939-40 season. As the likelihood of war in Europe grew the prospects of the tour decreased and the decision was eventually made to cancel. There would be no further cricket tours to New Zealand until the short Australian visit in March 1946, when an ill-prepared and weakened New Zealand side were trounced by Australia on a crumbling Basin Reserve wicket. $^{119}$

The Cahn tour to New Zealand epitomises many aspects of the conflicts within the cricketing and the Imperial world of the 1930s. That a Jewish furniture magnate, whose fortune was built on making chairs and tables available to working class and lower middle class families, spent his money on acquiring a Commonwealth-wide

\footnotetext{
${ }^{116}$ Otago Daily Times, 3 March 1939, p. 5.

${ }^{117}$ Ibid.

${ }^{118}$ For match report see Neely et. al. Men in White, pp. 172-73.

${ }^{119}$ Ibid. pp. 174-175.
} 
cricket team speaks volumes for the power and importance that cricket held in the period. That Cahn believed touring this team around the globe for the noble aim of 'spreading the game' would endear him to the 'old money' confirms the enduring belief in cricket's educative and crusading history. Conversely, the MCC's continued cold-shouldering of Sir Julien Cahn confirmed the stratified and snobbish nature of the game. To New Zealand audiences Cahn was not a 'new money' Jew using cricket to prove his worth to the establishment, but an exotic, wealthy English Lord, whose tour was for the benefit and growth of the game. That his team included the acclaimed New Zealand batsman Stewie Dempster, and that Cahn acquired another local talent in Giff Vivian was not criticised, but instead proved to local audiences that New Zealanders could make it in the big time. For the NZCC, the Cahn XI visit was yet another in a long line of tours that offered so much, but left them in much the same financially vulnerable position as before. Incapable of raising the revenue to develop a professional base they were painfully aware of the continued risk of losing players to the wealthy English professional league teams, not to mention the opportunistic figures such as Sir Julien Cahn. For the NZCC, amateur traditions and beliefs had been confronted by the cold hard realities of modern capitalism. 


\section{Conclusion}

This thesis sets out to explore the nature of cricket tours to New Zealand in the 1930s and the extent to which they have influenced or reflected questions of Empire and social change within the decade. The primary aims are to examine the meanings that the tours held for contemporaries; the symbolism of cricket in the wider conversations of the decade; and how the tours were conducted and depicted by the public, the press and by players. As the game of Empire, cricket presents an interesting but less explored aspect of New Zealand's relationship with Britain and other former colonies. The decade was chosen because of the shifting dynamics within the Empire and related changes within international cricket. New Zealand was the most geographically distant former colony of Britain and a minor test nation, but the topic offers an important story that invites exploration.

'Confirming Tradition, Confirming Change' builds on Greg Ryan's contributions to the understanding of the social history of New Zealand cricket and its relationship to the broader questions of New Zealand identity. Much of Ryan and J. P. Carr's research on this decade focuses on New Zealand's experience of cricket. However, this thesis focuses on the incoming tours, and thus New Zealand's interactions with other players, with peoples from other parts of Empire, and how they act as both receiver and distributor of social and cultural understandings within New Zealand. Incoming tours provide distinct and contained narratives in which the visitors are often the main players in the telling of the story, and their accounts offer an interesting contrast to those produced by the host country. Tourists bring with them a back-story, and in the 1930s this reflected the tension between the existing traditions within cricket and new realties and expectations across the Empire. The English sides that came to New Zealand were representatives of the MCC, an established institution in England but within these teams were cricketers with divergent interests, motivations and class differences. They were sides comprising amateurs and professionals, imperialists and suffragists, Princes of India and a miner from 
Nottingham. ${ }^{1}$ The West Indies were multi-racial in make-up, yet divided down colour lines, the South Africans were unified as a team but were representative of a racially separatist society. New Zealanders were aware, to some degree, that these tours were indicators of a changing British world. In part it was debated and expressed in the press but it was also apparent in the reactions of players and supporters during the tours.

What is abundantly apparent is how much the tours meant to New Zealanders. When the tourists arrived or departed crowds came to gaze at the stars; when evening parties were organised, the events were detailed in the newspapers the next day; when players were interviewed their views were given respect. The tours were part of the fabric of New Zealand society, part of the rhythm of summer and a means of understanding New Zealand's place within a wider cultural and social world - the British world. The cricketers were confirming bonds of Empire and friendship as had been the case in previous decades but the tours now took on newer dimensions. The increase in press photography, the influence of radio, and the omnipresence of cinema meant these cricketers were not just of interest because of their cricket skills, but for what they wore and what they said through particularly radio. They therefore were figures of influence and figures of debate beyond the sporting sphere. Though still cricketers that represented and upheld the traditions of the game and of society, they were now also understood as celebrities that thought toheroa soup was rather good (in the case of Duleepsinhji), or that stockings were a more prudent option than socks in women's cricket because of the mosquitoes, as was the view of the manager of the England Women's XI. New Zealand had always been fascinated by their cricketing visitors but now they much more accessible.

The variety of the tours to New Zealand in the 1930s reflects the broadening nature of international cricket in the period. The majority of sporting representatives to visit New Zealand before had been Anglo-Celts and male, with notable exceptions like the Fijian cricketers who toured in the 1895-96 season and an Indian hockey team in 1926. Although the majority of cricketers to New Zealand in the 1930s were still

\footnotetext{
${ }^{1}$ Bill Voce, like his good friend Harold Larwood was a miner before attaining a professional contract for Nottingham.
} 
predominantly white and male, there were notable exceptions. The inclusion of the Indian-born batting star Duleepsinhji in the MCC side that visited in 1929-30 meant New Zealand welcomed one of the true batting stars of the inter-war years and a figure who overseas was at the centre of racially-charged debates about the nature of cricket. The West Indies side which came to New Zealand very briefly a year later represented the multi-racial nature of the West Indies region and included Learie Constantine, a superstar of the game and a figures of great interest to the lucky Wellingtonians who saw him briefly. In both cases New Zealanders were excited to have these non-white cricketers and made attempts for their return - showing there was little resistance to multi-racial cricket. The England women who visited a few years later, were themselves representative of the changing face of international cricket, though they were, along with their male counterparts also representative of the English class system. The women's skill at cricket and their off-field poise meant any potential hostility was deflected.

While the non-white and female tourists were acknowledged and respected because of their talents it was the fact they were playing cricket that helped legitimise them. Cricket, and especially an international tour, facilitated an environment of goodwill and a sense of decorum towards opponents. Essentially it was because they were cricketers that they were treated with a degree of equality on par with their white male counterparts. That New Zealand was visited by non-white and female cricketers was clearly a progression but the conviviality and sense of respect for one's opponents and guests was not, this respect instead reflected the strong sense of sporting goodwill that cricket traditionally espoused.

The impact of the social, political and economic strains of the decade had varying degrees of influence on the tours. While the Depression clearly was a factor it did not impede the planning of cricket tours. Despite the limited streams of income and the expense of transporting players around the globe, administrators continued to look for cricketing opportunities, both for teams to visit New Zealand, and for New Zealand to tour England. If anything, cricket in those years of the Depression was a distraction from the realities, and even in 1932, at the worst of the economic 
troubles, Jardine's team attracted 17,000 spectators to the match against Wellington. ${ }^{2}$ His tour symbolises succinctly the conflict within cricket where a team imbued with the class structures and imperial grandiosity of English cricket could also perform with machine- like efficiency and the cold science of modern sporting practice. The prominence of this side and the indifference of New Zealanders to Australian complaints (because they had been rebuffed by Australia) meant this tour was a commercial success. Notwithstanding the monetary boost that Jardine's visit provided, the financial situation of New Zealand cricket did not improve later in the decade. Despite this unpleasant reality New Zealand cricket stuck to the belief that their cricket would improve through repeated exposure to English cricket, even if such tours were financially hazardous ventures.

There were two distinct types of tours to New Zealand during the 1930s. There were the full tours that may have included a shorter Australian leg, but principally involved the tourists spending several months travelling through New Zealand's cities and smaller towns, playing selections, attending events and generally 'spreading the gospel' of cricket. This is often how tours had been in the past because New Zealand was so far to visit that long stays were the only means of justifying the journey. The other type of tour was the short visit that generally occurred after the visitors' major tour of Australia. These visits involved matches in the major centres, were often at the end of the cricket season (hence the weather) and despite the higher status of these sides, were still generally relaxed occasions. These shorter tours offered less opportunity for reflection and were more like modern tour schedules.

Despite the often underwhelming performances by the local sides, the injurious financial cost of undertaking such expensive endeavours and the constant loss of the best players to England, the tours, short and long, kept coming. There was an understanding that the tours amounted to more than the outcome of the matches themselves, they were about being part of something bigger and contributing to something shared. Certainly there was a desire to win, or at least match the tourists because of national pride and local loyalties, but there was also a real sense of pride and excitement that came from a shared sense of association with the English teams.

\footnotetext{
${ }^{2}$ Though not everyone had to pay for the match.
} 
Although different, the tour by the South Africans also conveys a sense of shared experience and heritage through playing of cricket.

The fact that the game was so popular and cherished, despite the lack of success, raises an interesting point. Much of the mythologising of rugby comes from New Zealand's successes at this sport. ${ }^{3}$ The 1905 Originals, the 1924 Invincibles and the series win over South Africa in 1956 are identified as defining moments of national identity and national pride. Yet these cricket tours of the 1930s show that it is the participation and not necessarily the victory that is also important. Attention has been given to the winners in New Zealand sport, such as those All Black sides, often at the expense of the less tangible outcomes that sport and in particular cricket provided. These cricket tours meant more to the public and the players than the results, they were a means of conveying a way of behaving and a set of values that were to be followed in the matches but also beyond the sports field. Cricket was popular because it was a lesson in how be convivial and respectful to others. The England captain of the MCC side of 1935-36, E. R. T. Holmes sent an open letter to the Wellington captain J. R. Lamason, after Wellington's shock win, congratulating him on the result. For the players and importantly the public, this was a means of expressing and vindicating the point, that it was the playing of the game in a respectful style that was more important than who won.

This is not to say that defeats were not taken with some disappointment, but the fact that New Zealand cricketers, administrators and public continued to sacrifice their time and money to a game at which New Zealand was inferior clearly indicated that winning was secondary to participation. For the administrators, these tours were a chance to rub shoulders with their English contemporaries. For the home players it was a chance to match themselves against more experienced opponents, share stories and maybe advance a claim for a contract in England. For the press, such events potentially increased sales since tours provided pages of news stories and opportunities to photograph and interview famous overseas sports stars. For the

\footnotetext{
${ }^{3}$ Greg Ryan, The Contest for Rugby Supremacy: Accounting for the 1905 All Blacks, Christchurch, Canterbury University Press, 2005.
} 
public, the tours were a social outing; an escape from the problems of the decade; a chance to see faces that they had only read about, to watch stylish batsmen and skilful bowlers and maybe even to witness a rare home win. The touring sides themselves may have travelled to New Zealand to play cricket but in reality were often more interested in the touristic opportunities which the hosts eagerly provided.

The desire for an enjoyable visit to New Zealand is understandable as most of the tourists spent the Test series in Australia watching Bradman take toll of their team's bowling. Such an opportunity was denied New Zealand because the poor relationship between the two cricketing bodies meant Australia did not make an official visit in the decade. Despite this, it was Australia's cricketing ambition that provided New Zealand with many of its tours in the decade. South Africa and the West Indies, along with two star-studded Ashes-strength England teams, only toured New Zealand because they were undertaking major tours of Australia. In women's cricket the case was somewhat similar; the visit by the England Women's team was only organised after the tour to Australia was announced. The New Zealand administrators must be commended for their opportunism, for without these visits the 1930s calendar would have consisted solely of secondary MCC sides and the Julien Cahn XI.

There were moments within these tours where the expectation of a cricket tour was misunderstood or misinterpreted by one party or the other. This was most apparent in the last two tours by the MCC. With the MCC of 1935-36 there was a tendency to play defensive cricket that eventually led to press criticism and public outcry. For the public the cricket should have been more exciting and orientated towards achieving results, while the players presumably saw the matches as an exhibition of technique, where results were secondary to form. With the MCC of 1936-37 the cricket appeared to take second place to the fishing and hunting opportunities and a general interest in relaxing after the long Ashes series in Australia. This appeared to disappoint the local press who were hoping for more enthusiasm and effort from the guests. In both these tours the public and player expectations appear conflicted, a predicament that was not isolated to New Zealand but apparent in much of the cricket elsewhere, where amateur control appeared indifferent to public expectation. With both of these tours there is a tension between the traditionalism of the sport 
and newer expectations that may have been influenced by the changing nature of other sports in the world. The Berlin Games of 1936, a fusion of sports, nationalism and ideology, along with its predecessor the Los Angeles Games, brash and consumeristic, ushered in a vision of sport that was far removed from the distinctly amateur notions dominant in much British sport. New Zealand may have been on the edge of the world but these glitzy offerings, seen in highlight reels, could not but have affected how people perceived sport.

Connected to this question is the place of professionalism. New Zealand could not sustain anything more than a small number of professional cricketers but New Zealand cricket closely observed the amateur values of the game, which saw professionalism as a threat to the spirit and ethos of cricket. Despite this, many of New Zealand's finest cricketers left New Zealand in the decade for league cricket, the English county circuit or for Julien Cahn's side. For New Zealand the continued loss of its best players reduced its capacity to compete against the touring sides, confirmed its powerlessness to stop such defections but also in a broader sense showed the commercial direction that cricket was taking. Perhaps fittingly the last action of the New Zealand Cricket Council for the Julien Cahn tour was to accept meekly the loss of local star player Giff Vivian to the English professional scene.

This thesis 'Confirming Tradition, Confirming Change' has explored the impact of eight tours to New Zealand in the 1930s. New Zealand was visited by teams that in many regards reflected the ethos and beliefs in cricket that were first promulgated in the Victorian age. Sides were captained by amateurs and cricket was seen to represent the virtues and strengths of British culture and imperial values that New Zealand shared. The cricket tours of this decade emphasised the imperial bonds that were important at the time and which remained evident well into the middle of the twentieth century. Furthermore, all of the tours, to differing degrees, are illustrative of the changing nature of cricket, whether through the inclusion of non-white players and women within the international game, or the challenge to amateur values in an age of growing professionalism. Though these cricket tours were not nation defining events, they say a great deal about the nature and state of imperial relations and how New Zealanders reacted to and participated in events that impacted on New Zealand society and echoed across the Empire. 


\section{Bibliography}

\section{Primary Sources}

\section{Unpublished Official - Government and New Zealand Cricket Council}

Department of Industries and Commerce, Tourist and Publicity, Series 40, Sub No. 27, Visits - South African Cricket Team, TO 1175 40/27, Archives New Zealand, Wellington.

'New Zealand Cricket Council Management Committee Minute Book 1922-1934', New Zealand Cricket, Christchurch.

'New Zealand Cricket Council Management Committee Minute Book 1934-1949', New Zealand Cricket, Christchurch.

'New Zealand Council Minute Books 1911-1949' New Zealand Cricket, Christchurch.

\section{Unpublished Manuscripts}

Barden, Lesley, fl 1987-1989 Letters from Cricketers, MS-Papers-6778, Alexander Turnbull Library, Wellington.

Correspondence - Endell Wanklyne re Cricket and Racing, MS-Papers-1132-247, Alexander Turnbull Library, Wellington.

Hyman, Prue, 'Sport, Recreation and Leisure Organisations' (Chapter 10) - NZ Women's Cricket Council, 1933-1992 [Prue Hyman] Drafts and working papers, AAAC W4313 10 Folder 176, Archives New Zealand.

\section{Published}

\section{Newspapers and Periodicals}

The Evening Post 1929-1939

The Truth 1929-1939

The Dominion 1929-1939

New Zealand Free Lance 1929-1939

Otago Daily Times 1929-1939

New Zealand Herald 1929-1939

Otago Witness 1929-1939

New Zealand Observer 1929-1939 
The Auckland Star 1929-1939

The Bulletin 1929-1939

Auckland Weekly News 1929-1939

The Press 1929-1939

\section{Books and Articles}

Batchelor, Denzil, Game of a Lifetime, Werner Laurie, London, 1953.

Hammond, Walter, Cricket My Destiny, Stanley Paul \& Co., London, 1946.

Holmes, E. R. T., Flannelled Foolishness, London, Hollis \& Carter, London, 1957.

Reese, Daniel, Was it all Cricket? George Allen \& Unwin, London, 1948.

Reese, T. W., New Zealand Cricket 1914-1933, Whitcombe \& Tombs, Christchurch, 1936.

Sutcliffe, Herbert, For England and Yorkshire, London, Edward Arnold \& Co, 1935.

Turnbull, M. J. \& Allom, M. J. C., The Book of the Two Maurices; Being Some Account of the Tour of an MCC Team through Australia and New Zealand in the Closing Months of 1929 and the Beginning of 1930, E. Allom, London, 1930.

Warner, Sir Pelham, Cricket Between the Wars, Sporting Handbooks Limited, London, 1946.

\section{Annual Reports}

NZCC (New Zealand Cricket Council), Annual Report 1930, New Zealand Cricket, Christchurch,

NZCC, Annual Report 1931, Christchurch, The Council

NZCC, Annual Report 1932, Christchurch, The Council

NZCC, Annual Report 1933, Christchurch, The Council

NZCC, Annual Report 1935, Christchurch, The Council

NZCC, Annual Report 1936, Christchurch, The Council

NZCC, Annual Report 1937, Christchurch, The Council

NZCC, Annual Report 1939, Christchurch, The Council

\section{Match Programmes}

New Zealand Cricket Museum Printed Ephemera Collection, Wellington 


\section{Secondary Sources}

\section{Books, Chapters and Articles}

Allen, Dean, 'South African Cricket, Imperial Cricketers and Imperial Expansion, 1850-1910', The International Journal of the History of Sport, vol. 25, no. 4, March 2009, pp. 443-471.

Andewes, Frazer, 'They play in your home': cricket, media and modernity in pre-war Australia ', The International Journal of the History of Sport, vol. 17, no. 2, pp. 93110.

Arrell, Robert, Waitomo Caves - A Century of Tourism, Waitomo Caves Museum Society Inc, Waitomo, 1984.

Bandyopadhyay, Sekhar (ed.), India in New Zealand, Local Identities, Global Relations, Otago University Press, Dunedin, 2010

Barber, Laurie, New Zealand. A Short History, Century Hutchinson, Auckland, 1989.

Bassano, Brian \& Smith, Rick, The West Indies in Australia 1930-31, Apple Books, Tasmania, 1990.

Bassett, Michael, Tomorrow Comes the Song: A Life of Peter Fraser, Penguin, Auckland, 2000.

Baxendale, John and Pawling, Christopher, Narrating the Thirties, A Decade in the Making: 1930 to the Present, Macmillan, Basingstoke, 1996.

Beckles, Hilary, The Development of West Indies Cricket, Pluto Press, London, 1999.

Belich, James, Paradise Reforged, A History of the New Zealanders from the 1880s to the year 2000, Penguin, Auckland, 2001.

Bennett, James, 'Maori as honorary member of the white tribe', The Journal of Imperial and Commonwealth History, Vol 29, no. 3, 2001, pp. 33-54.

Birley, Derek, A Social History of English Cricket, Aurum Press, London, 1999.

Bornholt, Jenny; O'Brien, Gregory \& Williams, Mark (ed.), An Anthology of New Zealand Poetry in English, Oxford University Press, Auckland, 1997.

Brittenden, R. T., Great Days in New Zealand Cricket, A. H. \& A. W. Reed, Wellington, 1958.

Barbara Brookes, Annabel Cooper \& Robin Law (ed.), Sites of Gender, Women, Men and Modernity in Southern Dunedin, 1890-1939, Auckland University Press, Auckland, 2003. 
Brothers, Barbara \& Gergits, Julia M., 'British Travel Writers, 1919-1939', Dictionary of Literary Biography, Volume One Hundred Ninety-Five, Bruccoli Clark Layman Book, Detroit, 1998.

Brown, Judith M., \& Louis, W. M. Rogers, (ed.), The Oxford History of the British Empire, vol. 4, The Twentieth Century, Oxford University Press, Oxford, 1999.

Byrnes, Giselle (ed.), The New Oxford History of New Zealand, Oxford University Press, Melbourne, 2009.

Calder, Angus, 'A Man for all Cultures: The Careers of Learie Constantine', Culture, Sport, Society, vol 6, no. 1, Spring 2003, pp. 19-42.

Cardus, Neville, A Fourth Innings With Cardus, Souvenir Press, London, 1981.

Cashman, Richard, O'Hara, John \& Honey, Andrew (ed.), Sport, Federation, Nation, Walla Walla Press, Sydney, 2001.

Cashman, Richard, Paradise of Sport, Oxford University Press, Melbourne, 1995.

Carman, Arthur H., New Zealand International Cricket 1894-1974, A. H. \& A. W. Reed Ltd., Wellington, 1974.

Coldham, James P, Lord Hawke - A Cricketing Legend, Tauris Parke, London, 2003.

Coney, Sandra, Standing in the Sunshine, Penguin Books, Auckland, 1993.

Curran, James \& Ward, Stuart, The Unknown Nation, Australia After Empire, Melbourne University Press, Melbourne, 2010

Davies, Peter J., 'Bowling Maidens Over: 1931 and the Beginnings of Women's

Cricket in a Yorkshire Town', Sport in History, vol 28, no 2, pp. 280-298.

Dawson Graham, Test Cricket Lists, The Five Mile Press, Balwyn, 1992.

Dennan, Rangitiaria with Ross, Annabell, Guide Rangi of Rotorua, Whitcombe and Tombs Ltd Christchurch, 1968.

Diawara, Manthia, 'Englishness and Blackness: Cricket as Discourse on Colonialism', Callaloo, vol. 13, no 4, Autumn, 1990, pp. 830-844.

Down, Michael, Archie - A Biography of A. C. Maclaren, George Allen \& Unwin, London, 1981.

Downes, Aviston, 'From Boys to Men: Colonial Education, Cricket and Masculinity in the Caribbean, 1870-c.1920', International Journal of the History of Sport, vol. 22, no 1, pp. 3-21.

Else, Anne (ed.), Women Together, Daphne Brasell Associates Press \& Historocal Branch of Intenral Affairs, Wellington, 1993.

Graves, Robert and Hodges Alan, The Long Weekend, A Social History of Great Britain, Abacus, London, 1940, (1995). 
Green, Benny ed., Wisden Anthology 1864-1900, Macdonald and Jane's Publishers Ltd, London, 1979, (1985).

Green, Benny ed., Wisden Anthology 1900-1940, Queen Anne Press Book Company, London, 1983, reprinted by Macdonald and Co., 1985.

Green, Benny ed., Wisden Anthology 1940-1963, Queen Anne Press Book Company, London, 1982, reprinted by Macdonald and Co., 1985.

Green, Benny ed., Wisden Anthology 1963-1982, Queen Anne Press Book Company, London, 1983, reprinted by Macdonald and Co., 1985.

Guha, Ramachandra, A Corner of a Foreign Field, Pan Macmillan, London, 2003.

Gustafson, Barry, From the Cradle to the Grave, Reed Methuen, Auckland, 1986.

Guttmann, Allen, Games \& Empires, Modern Sports \& Cultural Imperialism, Columbia University Press, New York, 1994.

Guttmann, Allen, Women's Sport - A History, Columbia University Press, New York, 1991.

Guttmann, Allen, Sports Spectators, Columbia Press, New York, 1986.

Hamilton, Duncan, Harold Larwood, Quercus, London, 2009.

Hargreaves, Jennifer, Sporting Females, Routledge, London, New York, 1993.

Hargreaves, Jennifer, Critical Issues in the History and Sociology of Women's Sport, Routledge, London \& New York, 1994.

Harper, Marjory, "Personal contact is worth a ton of text-books': educational tours of the empire, 1926-39', The Journal of Imperial and Commonwealth History, vol 32, no 3, 2004, pp. 48-76.

Hawes Joan L., Women's Test Cricket - The Golden Triangle 1934-84, Book Guild, Lewes, 1987.

Hill, Jeffrey, Sports, Leisure and Culture in 20th Century Britain, Palgrave, New York, 2002.

Hinchcliff, John (ed.), The Nature and Meaning of Sport in New Zealand, The Centre, Auckland, 1978.

Hoberman, John, Darwin's Athletes: How Sport has Damaged Black America and Preserved the Myth of Race, Houghton Mifflin Co., Boston, 1997.

Holland, Robert, The Pursuit of Greatness, Fontana Press, London, 1991.

Holt, Richard, Sport and the British, Clarendon Press, Oxford, 1989.

Huggins, Mike \& Williams, Jack, Sport and the English, 1918-1939, Routledge, London, 2006. 
James, C. L. R, Beyond a Boundary, Vintage, London 1963 (2005).

Johnson, Robert, British Imperialism, Palgrave Macmillan, Basingstoke, Hampshire, 2003.

Keys, Barbara J., Globalizing Sport: National Rivalry and International Community in the 1930s, Harvard University Press, Cambridge, Mass., 2006.

Kirk-Green, Anthony, 'Badge of Office? Sport and his Excellency in the British Empire', The International Journal of the History of Sport, vol. 6, no. 2, 1989, pp. 218-241.

King, Michael, The Penguin History of New Zealand, Penguin, Auckland, 2003

Lake, Marilyn \& Reynolds, Henry, Drawing the Global Colour Line, Melbourne Univeristy Press, Melbourne, 2008.

Lambert, John, "An Unknown People' : Reconstructing British South African Identity', The Journal of Imperial and Commonwealth History, vol 37, no 4, pp. 599617.

McCarthy, Conal, Exhibiting Maori, Berg, Oxford, 2007.

McClure, Margaret, The Wonder Country - Making New Zealand Tourism, Auckland University Press, Auckland, 2004.

McConnell, Lyn \& Smith, Ian, The Shell New Zealand Cricket Encyclopaedia, Moa Beckett, Auckland 1993.

McDevitt, F., Patrick, May the Best Man Win: Sport, Masculinity, Nationalism in Great Britain and the Empire, 1880-1935, Palgrave MacMillan, New York, 2008.

McKinnon, Malcolm, 'New Zealand in the World', in Sinclair, Keith (ed.), The Oxford Illustrated History of New Zealand, Otago University Press, Auckland, 1990.

Macintyre, Stuart, 'History Wars and the Imperial Legacy in the Settler Societies', chapter in Buckner, Phillip \& Francis, R. Douglas, (ed.), Rediscovering the British World, Calgary University Press, Calgary, 2005.

McIntrye, W. David, 'When, If Ever, did New Zealand become independent?', The Jim Gardner Lecture 2002, The Canterbury History Foundation, 2002.

Macpherson, Deirdre, The Suffragette's Daughter, Betty Archdale, Rosenburg Publishing, Kenthurst, 2002.

Mangan, J. A. (ed.)., The Cultural Bond, Sport, Empire, Society, Frank Cass, London, 1992.

Mangan, J. A., The Games Ethic and Imperialism, Viking (Penguin), Harmondsworth, 1986. 
Mann, Owen, 'The Cultural Bond? Cricket and the Imperial Mission', The International Journal of the History of Sport, Vol. 27, no. 13, September 2010, pp. 2187-2209.

Mein Smith, Philippa, A Concise History of New Zealand, Cambridge University Press, Cambridge, 2005.

Mein Smith, Philippa, Hempenstall, Peter and Goldfinch, Shaun, Remaking the Tasman World, Canterbury University Press, Christchurch, 2008.

Mulholland, Malcolm, Beneath the Maori Moon, An Illustrated History of Maori Rugby, Huia Press, Wellington, 2009.

Murray, Bruce \& Merrett, Christopher, Caught Behind - Race \& Politics in Springbok Cricket, Jointly published by Wits University, Johannesburg \& University of KwaZulu-Natal Press, Scottsville 2004.

Neely, D. O., King, R. P., Payne, F. K., Men In White, The History of International Cricket, Moa Publications, Auckland, 1986.

Neely, Don, The First 50 Tests, Don Neely, Self Published, Wellington, 2010.

Olssen, Erik, 'Depression and War' in Sinclair, Keith (ed.), The Oxford Illustrated History of New Zealand, Oxford University Press, Auckland, 1990.

Oliver, W. H., 'The Awakening Imagination', in Oliver, W. H. and Williams, B. R., (ed.), The Oxford History of New Zealand, Oxford University Press, Wellington, 1981, (1988).

Owen, Alwyn (ed.), Snapshots of the Century, 'Spectrum' Cover 100 Years of New Zealand History, Tandem Press, Auckland, 1998.

Patterson, Brad, Sports, Society and Culture in New Zealand, Stout Research Centre, Victoria University of Wellington, Wellington, 1999.

Perkin Harold, 'Teaching the Nations How to play: Sport and Society in the British Empire and Commonwealth, International Journal of the History of Sport, Volume 6, No. 2, 1989, pp. 145-155.

Phillips, Jock, A Man's Country, Penguin Books, Auckland, 1987.

Piesse, Ken, The Ashes, Viking, (Penguin Group), Camberwell, 2007.

Polley, Martin, 'The Amateur Ideal and British Sports Diplomacy, 1900-1945', Sport in History, vol. 26, no. 3, 2006, pp 450-467.

Porter, Bernard, The Lion's Share, Longman, London and New York, 1975.

Rae, Simon, It's Not Cricket, Skulduggery, Sharp Practise and Downright Cheating in the Noble Game, Faber and Faber, London, 2001. 
Rijks, Miranda, The Eccentric Entrepreneur, The History Press, Chalford, 2008.

Ryan, Greg, The Making of New Zealand Cricket 1832-1914, Frank Cass, London, 2004.

Ryan, Greg, "Extravagance of Thought and Feeling': New Zealand Reactions to the 1932/33 Bodyline Controversy', Sporting Traditions, vol 13, no 2, May 1997, pp. 41-58.

Ryan, Greg, "Britishers Anxious to Appear on the Cricket Map' Anglo-New Zealand Cricket in the Imperial Context 1927-58', The International Journal of the History of Sport, vol. 25, no. 1, January 2008, pp. 18-40.

Ryan, Greg, 'Few and Far Between: Maori and Pacific Contributions to New Zealand Cricket, Sport in Society, vol 10, no. 1, pp 71-87.

Ryan, Greg, 'Anthropological Football: Maori and the 1937 Springbok Rugby Tour of New Zealand', The New Zealand Journal of History, Vol. 34, no. 1, April 2000, pp. 60-79.

Sandiford, Keith Cricket and the Victorians, Scolar Press, Aldershot, 1994.

Silvennoinen, Martti, 'The Many Levels of Sports Narration', Historical Social Research, vol. 31, no 1, 2006, pp. 230-244.

Sinclair, Keith, A Destiny Apart, Allen \& Unwin, Wellington, 1986.

Sinclair, Keith, A History of New Zealand, Penguin, [Auckland], 1959, [1987]

Stoddart, Brian \& Sandiford, Keith (ed.), The Imperial Game, Manchester University Press, Manchester, 1999.

Stoddart, Brian, 'Sport, Cultural Imperialism, and Colonial Response in the British Empire', Comparative Studies in Society and History, 30, 1988, pp. 649-673.

Thompson, Andrew S., Imperial Britain, The Empire in British Politics c. 18801932, Pearson Education Limited, Harlow, 2000.

Vamplew, Wray \& Stoddart, Brian (ed.), Sport in Australia - A Social History, Cambridge University Press, Cambridge, 1994.

Wagg, Stephen (ed.), Cricket and National Identity in the Post-Colonial Age: Following On, Routledge, London, 2005.

Ward, Stuart (ed.), British Culture and the end of Empire, Manchester \& New York, Manchester University Press, 2001.

Watson, Geoff, 'Affirming Indian Identities? An Analysis of Imperial Rhetoric and Orientalism in the tour of Indian Hockey Teams to New Zealand in 1926, 1935 and 1938', Sporting Traditions, Vol. 21, no. 2, May 2005. 
White, Hayden, The Content of the Form, The John Hopkins University Press, Baltimore \& London, 1987.

Williams, Jack 'Çricket' in Mason, Tony (ed.), Sport in Britain- A Social History, Cambridge University Press, Cambridge, 1989.

Williams, Jack, Cricket and Race, Berg, Oxford, 2001.

Williams, Jack, Cricket and England: A Cultural and Social History of the inter-war years, Frank Cass, London, 1999.

Williams, Jack, "The Really Good Professional Captain Has Never Been Seen!' Sport in History, vol. 26, no. 3, 2006, pp. 429-449.

\section{Unpublished Theses and Research Essays}

Carr, J. P., 'The First Golden Age? A Social History of New Zealand Cricket 191439', MA Thesis, University of Canterbury, 2002

McConnochie, Adam, 'Explain change and continuity in New Zealand society postwar through the prism of change and continuity in New Zealand cricket.' Canterbury University History Department, History 480, 2005.

McIntrye, W. David, 'When, If Ever, did New Zealand become independent?', The Jim Gardner Lecture 2002, The Canterbury History Foundation, 2002.

Wightman, Sue, 'Problem Men' to 'Problem Women': a study of gender in New Zealand, c. 1890 to c. 1930 ' MA thesis, Victoria Univeristy of Wellington, 1999.

\section{Websites}

ESPN cricinfo, www.cricinfo.com

Cricket Archive, www.cricarchive.co.uk

Television New Zealand, www.tvnz.co.nz

Te Ara, The Encyclopaedia of New Zealand, www.teara.govt.nz

Oxford Dictionary of National Biography, www.oxforddnb.com 